\title{
Centenarios, 1511-2011: conclusión de la estancia rafaelesca de la Signatura y nacimiento de Vasari. Reflexiones, conjeturas
}

\author{
Diego SuÁrez Quevedo \\ Universidad Complutense de Madrid \\ Departamento de Historia del Arte II (Moderno) \\ disuarez@ghis.ucm.es
}

Recibido: 21 de febrero de 2011

Aprobado: 20 de julio de 2011

\section{RESUMEN}

Como homenaje a Rafael Sanzio y su Estancia vaticana de la Signatura, concluida en 1511, es decir hace quinientos años, se realiza aquí un estudio y todo tipo de reflexiones sobre esta paradigmática obra en su contexto y valorando sus alcances y aportaciones como hito de la cultura artística occidental. Bajo similares presupuestos se glosa la figura de Giorgio Vasari, en el quinto centenario de su nacimiento en Arezzo, haciendo hincapié ante todo en sus Vite (1550 y 1568) como eslabones fundamentales de la literatura artística, asimismo claves en la cultura occidental.

Palabras clave: Rafael, Urbinate, Julio II, Giuliano della Rovere, Pietro Bembo, Estancias Vaticanas, Estancia de la Signatura, Piero della Francesca, Bramante, Basílica de San Pedro del Vaticano, Bastiano da Sangallo detto Aristotile, Miguel Ángel, Vasari, Vite, Cosme I de’Medici.

\section{Centenaries, 1511-2011: end of the Stanza della Signatura by Raphael and Vasari's birth. Reflections, Conjetures}

\begin{abstract}
As a tribute to Rafael Sanzio and his Satana della Signatura, finished in 1511, that is, five hundred years ago, here, we carry out an study with all kind of reflections about this paradigmatic work, into its context and valueing its implications and contributions as a milestone of the western artistic culture. With similar assumptions we gloss the figure of Giorgio Vasari, in the fifth hundred anniversary of his birthday in Arezzo, putting special emphasis on his Vite (1550 and 1568) as fundamental links of the artistic literature, also milestones of the western culture.
\end{abstract}

Keywords: Raphael, Urbinate, Giulio II, Giuliano della Rovere, Pietro Bembo, Stanze Vaticane, Stanza della Signatura, Piero della Francesca, Bramante, Basilica di San Pietro del Vaticano, Bastiano da Sangallo detto Aristotile, Michelangelo, Vasari, Vite, Cosimo I de'Medici.

\section{SUMARIO}

A Roma para alcanzar la gloria. Estancia vaticana de la Signatura. Signatura, bóveda. Signatura, frescos parietales. La Disputa. La Escuela de Atenas. El Parnaso. Las Virtudes. Colofón no conclusivo. [Addenda, Piero]. Vasari, las Vite. Rafael, según las Vite. Vasari, pintor. Vasari, arquitecto. 
Cuando el 14 de agosto de 1511, se descubría, y así se mostraba a la corte pontificia de Julio II, la primera fase, ya concluida, de los frescos de la bóveda de la Capilla Sixtina, la admiración e impacto fueron grandes y generales. Muy probablemente fue a partir de ello, y como homenaje a su autor, cuando el Urbinate decidió añadir la figura de Heráclito en primer plano del amplio proscenio de la Escuela de Atenas, con el fresco ya concluido tal como los encastres del enlucido demuestran; la imagen del filósofo de Éfeso con los rasgos de Miguel Ángel y pintada al "estilo del propio Buonarroti", debemos entenderla no sólo como símbolo del avance del conocimiento mediante la oposición de los contrarios, en sintonía con el pensamiento del griego e ideales del artista florentino ${ }^{1}$, sino también como expresión, propia del contexto, del genio creativo ligado a procesos de abstracción y melancolía. De este modo y en aquel preciso momento cuando menos, todo tipo de rivalidades entre Rafael y Miguel Ángel, quedaban subsumidas y obviadas mediante un acto de profundo reconocimiento e incluso de exaltación del "supuesto rival", ante su obra y la consiguiente aportación a la historia de la pintura y de la cultura artística.

A fines de este año, 1511, noviembre, Rafael completaba sus pinturas de la Stanza della Segnatura o Signatura ${ }^{2}$, y asimismo, es 1511 el año del nacimiento en Arezzo, 30 de julio, de Giorgio Vasari, cuya aportación a la historia del arte occidental es clave, tanto como para ser considerado "padre" de la misma, término que usualmente le es aplicado. Entreveradas o no, so pretexto de ambos centenarios, y tratándose a todos los niveles de hitos del devenir artístico europeo, me propongo realizar aquí un conjunto de reflexiones, conformando un muy especial díptico, a modo de homenaje a ambos maestros desde luego y pienso que significativas y oportunas, exentas de todo afán conclusivo y siempre abiertas, buscando un deseable grado de interdisciplinaridad y fundamentadas en el oportuno contexto que las avale y valide.

En aras de una cierta congruencia, tanto por cronología en razón de las respectivas obras como por sus aportaciones -de Rafael y Vasari, se entiende- a la cultura artística y ámbitos de sus producciones, me referiré en primer lugar a la Camera della Segnatura ${ }^{3}$, como la denomina el aretino, que, entre fines de 1508 y 1511, realizara Rafael en los palacios vaticanos bajo comitencia del papa Julio II, Giuliano della Rovere, pontífice entre 1503 y 1513. El Urbinate y muy especialmente el conjunto de sus Estancias Vaticanas ${ }^{4}$, constituyen un auténtico núcleo medular de

1 Oposición y/ o tensión no resuelta, incluso formal y de planteamiento, son notorias en estas pinturas de la bóveda de la Sixtina, 1508-1512; muy significativas entre lo que podemos considerar el continente arquitectónico-escultórico con los Ignudi, pintura en todos los casos, y los contenidos, entendidos como las escenas del Génesis; la "invasión" de los respectivos campos pictóricos que, en principio, la reticula parecía asignarles, es constante.

2 Lo confirman sendas inscripciones en el fresco del Parnaso y en el denominado Luneto de las Virtudes.

3 Ante todo remitimos al completísimo y muy esclarecedor estudio, aún hoy perfectamente válido y con una más que deseable interdisciplinaridad, de DE VECCHI, Pierluigi: "Biografía y estudios críticos" (pp. 81-128) y concretamente para la "Estancia de la Signatura" (pp. 100-104), en La obra pictórica completa de Rafael. Barcelona, Noguer, 1972, que es la que he consultado y la $2^{\text {a }}$ ed. española ( $1^{\mathrm{a}}$ ed. española, 1968; $1^{\mathrm{a}}$ ed. italiana, Milán, Rizzoli, 1966).

${ }^{4}$ La primera de las Estancias es ésta, de la Signatura, 1508/ 1509-1511; la segunda conocida como 
lo que han sido calificados, muy certeramente a mi juicio, de aquellos increibles veinte años, referidos a Roma, 1500-1520; fecha esta última de la prematura muerte de Rafael con tan sólo treinta y siete años ${ }^{5}$, ya que había nacido en Urbino en 1483.

\section{A Roma para alcanzar la gloria}

Epígrafe que quiere englobar el intervalo 1508/ 1509-1520, esto es los doce años restantes de vida y de actividad frenética de Rafael en la Ciudad Eterna, tanto en pintura como en arquitectura, y, de este modo, conseguir fama e inmortalidad tal como entonces eran concebidas; gloria, pretender ser una suerte de imbricación de ambos términos que alude y define este auténtico leit-motiv del contexto, de hondo trasfondo humanístico y meta de toda actividad intelectual, así como referencia precisa a la Antigüedad Clásica. El ya señalado epitafio del monumento funerario del Urbinate en el Panteón de Roma lo ratifica y confirma.

En efecto, para mí tengo que este reclamo sobre Rafael y Roma, resulta tan contundente y veraz como epígrafe, al tiempo que fue su consecuencia, del ya propuesto -En Florencia para aprender ${ }^{6}$ - respecto al período 1504-1508, en el sentido de que ya nada podía aportarle ni su Urbino natal, ni Città di Castello ni Perugia, donde había realizado su aprendizaje y primera actividad pictórica, que nos consten al menos; no le ofrecían a la sazón las posibilidades profesionales y el horizonte cultural anhelados, decidiendo entonces trasladarse a la ciudad del Arno. Aquí completó su formación y aprendió -y mucho, en efecto- de Leonardo y Miguel Ángel, ante todo, tal y como no deja de precisar Vasari, de sus diseños y actividades florentinas entre 1501 y 1505/ 1506; el "pulso" entre ambos respecto a sus propuestas de batallas del Palazzo Vecchio (Anghiari y Cascina, respectivamente) y

Stanza di Eliodoro o Estancia de Heliodoro, 1511-1514, ya concluida bajo el pontificado de León X; la tercera es la Estancia del Incendio del Borgo, 1514-1517, ya enteramente bajo el citado papa Medici y la última es la conocida como Sala de Constantino, no Estancia, proyectada en gran parte por el Urbinate y sólo realizada tras su fallecimiento por sus discípulos, ante todo Giulio Romano y Giovan Francesco Penni, a partir de 1523 y bajo el pontificado de Clemente VII, el otro papa Medici. Ocupan el lado septentrional del piso alto del palacio de Nicolás III, en parte reformado por Nicolás V, entre la Torre Borgia y el Patio de San Dámaso, mirando hacia el bramantesco Patio del Belvedere y sobre los Apartamentos Borgia, decorados entre 1492-1494 por Bernardino Pintoricchio, que Julio II no quiso habitar.

5 Prácticamente los mismos que vivió Mozart [casi treinta y seis], por lo que ambas figuras y sus genialidades han sido, acaso en exceso, parangonadas; Giorgio Vasari en sus Vite, Florencia, 1550 (edición torrentina o torrentiniana), incluye al final de la biografía de Rafael da Urbino, tanto la elegía que escribiera Castiglione como un amplio epitafio de Pietro Bembo, cuya conclusión figura en la tumba del Urbinate en el Panteón de Roma: ILLE HIC EST RAPHAEL, TIMVIT QVO SOSPITE VINCI/ RERVM MAGNA PARENS, ET MORIENTE MORI; esto es, aquí yace aquel Rafael, del cual NATURA, aquí expresada como Rerum Magna, temió ser vencida cuando el artista vivía, y cuando murió temió morir con él. Como es sabido, estos epitafios, loas y elogia, no fueron incluidos, en general, por Vasari en su edición de las Vite, giuntina o giuntiniana de Florencia, 1568; en este caso sí, seguramente más en función de los autores citados que otra cosa.

${ }^{6}$ Así se propone como capítulo II: In Firenze per imparare (pp. 21-47), en la monografía de JONES, Roger.-PENNY, Nicholas: Raffaello. Milán, Jaca Book, 1983. 
los debates subsiguientes; esa Scuola del Mondo, como será certeramente calificada por Benvenuto Cellini, lo fue en toda su hondura para Rafael ${ }^{7}$.

Según testimonio precisamente de Vasari, antes de que Julio II encargara a Rafael el ciclo pictórico de las Estancias -a partir de 1514 ratificada y refrendada la comitencia por su sucesor León X- ya existían en algunas paredes pinturas (de Piero della Francesca y Luca Signorelli, por ejemplo), e iniciada estaba una nueva decoración a cargo de un grupo de pintores, entre los que figuraban Perugino, Sodoma, Peruzzi y Bramantino; cuando el pontífice pudo comprobar los diseños y primeros resultados de Rafael, los pintores aquí actuantes fueron licenciados, haciendo tirar por tierra todas sus historias y encargando la obra, al completo, al Urbinate.

Con total exactitud no es posible saber cuándo Rafael abandonó Florencia, según Vasari precipitadamente y dejando obras inconclusas, y se trasladó a Roma a requerimiento de Julio II. En la ciudad del Arno residía aún en abril de 1508 y el primer dato seguro de su estancia en la corte pontificia es una orden de pago (13 de enero de 1509) de la tesorería papal, ad bonum computum picturae camerae ... testudinatae ("cámara abovedada"), verosímilmente la Estancia de la Signatura; por tanto es más que probable que ya desde fines de 1508 laborara en Roma.

El convocar a Rafael por parte del Papa, se produjo tras consejo y sugerencia de Bramante de Urbino, a decir -una vez más- del aretino, lo cual resulta ni del todo convincente ni suficiente aval al respecto, a pesar del apoyo y recomendación de su paisano que trabajaba como arquitecto papal de la nueva basílica de San Pedro del Vaticano y del Belvedere de Julio II.

La sugerencia y recomendación de Agostino Chigi sí pudieron ser definitivas en relación con Rafael y el encargo de esta crucial obra pictórica, como ha sido propuesto ${ }^{8}$. Agostino no sólo era el banquero del papa Della Rovere, sino que la amistad, connivencia y afinidad entre ambos eran totales, incluso como para compartir escudos y divisas; baste recordar que la celebérrima Loggia de Psiche pintada por Rafael y discípulos en 1517, ya fallecido Julio II por tanto, en el Viridario Chigi, luego Farnesina, que el banquero sienés se había hecho construir ${ }^{9}$ como residencia suburbana $^{2}$ en el Trastevere romano, queda presidida en su bóveda por el roble o quercia de la Casa della Rovere.

Esta sugestiva hipótesis, para el que escribe con muchos puntos de coherencia, insiste, a los niveles de comitencia y exigencias en que nos movemos, en que Rafael c. 1508, era un pintor de fama relativa, muy querido por importantes familias florentinas que le habían encargado obras de carácter privado, ante todo Madonne y

7 Con Soderini y Maquiavelo al frente de la Signoria, Florencia había superado brillantemente las crisis de fines del Quattrocento (Savonarola, caída y expulsión de los Medici, constantes pugnas entre Arrabbiati y Piagnoni) que, de todos modos, resultará efímera: son las que Chastel denominó Incertidumbres Florentinas, por contra de las Certidumbres Romanas, que harán de la Urbs la cabeza cultural del Cinquecento, cuyas bases, de todos modos, estuvieron en las primeras; como eje de ida y vuelta Florencia-Roma, conviene considerarlo (vid. SUÁREZ QUEVEDO, Diego: "Leonardo, Miguel Ángel y Rafael, 2004. Hitos de la Historia del Arte quinientos años después “, Cuadernos de Filología Italiana, vol. 11 (2004), pp. 99-112).

${ }^{8}$ STRINATI, Claudio: Raffaello. Florencia, Giunti, 1998, pp. 27-28, en apartado con la Signatura, Estancia de Heliodoro y obras coetáneas, bajo el significativo epígrafe: Una Scuola per pochi, pp. 26-37.

${ }^{9}$ Entre 1507 y 1509, según proyecto del arquitecto y pintor, asimismo de Siena, Baldassare Peruzzi. 
retratos, y en su haber no existían aún pinturas de historia de gran aliento y alcance ${ }^{10}$ -una gran obra y por consiguiente un gran encargo, cabría decir- como el que, en las Estancias vaticanas al fin lograría enseguida y donde ampliamente desarrollaría su genio e inventiva. La pintura clave, según esta interesantísima propuesta, sería la celebérrima Galatea o Triunfo de Galatea, adelantando su fecha a 1508-1509, desde la usual y también convencional de c. 1511, tras los frescos de la Signatura. Con la misma Agostino Chigi quedó encantado, tanto como para la recomendación de su autor al Papa; la dureza de formas y modos, en comparación con la Sagrada Familia Canigiani $^{11}, 1507-1508$ y, sobre todo, con los propios frescos de la Signatura, no queda satisfactoriamente explicada por el neoaticisno ambicionado en la obra; sería el caso, por ejemplo, del impenetrable mar que no logran horadar algunas figuras.

Si se acepta esta hipótesis, esta pintura mitológica se convierte en el gozne preciso entre el Gran Rafael y el Excelso Urbinate de la etapa romana; en otro orden de cosas, este fresco de la residencia Chigi, fue asimismo significativo en el sentido de que Agostino atendía así, al parecer, el consejo de su padre, "banquero viejo y experto", que había insistido en el encargo a Rafael, pues "aún no cobraba precios desorbitados", lo que redunda en la idea de una fama muy relativa del pintor entonces, como quedó dicho.

Sea como fuere, desde fines de 1508 Rafael encara las pinturas de la Signatura, enorme reto para el artista y al tiempo esa gran oportunidad, con toda seguridad esperada y anhelada, y que, desde luego, no desaprovechó. Tras las oportunas remodelaciones y acondicionamientos por parte de Bramante en la Estancia, puso manos a la obra, diseñando y conformando uno de los hitos más espectaculares y definitivos del arte occidental y referente continuo a posteriori, a su vez primer capítulo de una secuencia que sólo la muerte truncó; en esta primera Estancia vaticana, como trataré de ir exponiendo, Rafael alcanza cotas sublimes entre grandiosidad y belleza, no exentas de ragione, concebida a niveles máximos de regularidad y normativa en la visión y representación, y entendida como un todo indisoluble y de total maridaje entre prespectiva, proporción y simetría, en pro de lograr un todo ponderado y equilibrado.

\section{Estancia vaticana de la Signatura}

Esta Estancia pasó a ser sede, al parecer en 1540, del Tribunal de la Signatura Gratiae; de ahí la denominación que se impuso y que aún hoy mantiene. En principio fue estudio y biblioteca privada ${ }^{12}$ de Julio II y, en esta línea y bajo esta consideración, fue

${ }^{10}$ La Pala Baglione o Traslado de Cristo al sepulcro, fechada en 1507, era hasta entonces su pintura de historia de más empeño, realizada para esta importante familia de Perugia.

11 Un cotejo entre la Galatea rafaelesca y sus Sibilas Chigi, 1511, de la romana Santa Maria della Pace, no haría más que incidir en lo dicho; en sólo tres años es notorio el vertiginoso avance del Urbinate.

12 Un alto zócalo con taraceas de madera, obra de Fra'Giovanni da Verona, quedó dispuesto en tres de las paredes de esta Estancia; en la correspondiente al Parnaso por problemas de espacio, se optó por pinturas al fresco y son hoy las únicas conservadas. Seguramente durante el Sacco'1527, los paneles lígneos desaparecieron y posteriormente, ya bajo Paulo III al parecer, Perin del Vaga realizó las actuales pinturas de base: hermas en grisalla y fingidos relieves broncíneos; ¿a partir de diseños rafaelescos? 
planteado el programa, y desde este punto de partida es preciso estudiar y valorar los diseños y pinturas de Rafael.

En lo que a programas se refiere y sin tener en cuenta aspectos artísticos, ninguna de las restantes Estancias es comparable a la Signatura; en los siguientes tres ámbitos vaticanos, se pretendía un alcance e impacto más directo en el espectador, si se quiere de programas tanto más prosaicos cuanto claros y efectivos y, desde luego, de menor contenido y hondura intelectuales, al tiempo que plenos de una retórica menos elaborada y refinada, por más que dentro de los cánones específicos, sea calificable de alta retórica.

Por su parte, en la Signatura resulta todo más cuidado, elaborado y conceptual, aceptando y asumiendo la tradición pero superándola y dotándola de nuevos significados y planteamientos que, en total sintonía, va aunando Antigüedad Clásica, Cristianismo y Humanismo, o sea ideas y presupuestos de un profundo humanismo cristiano planteado sin contradicciones, carente de ribetes críticos y de concenso entre platonismo, neoplatonismo y aristotelismo.

Sin seguridad plena, pero con datos y testimonios indirectos que parecen avalarlo, y contando con aportaciones e importantes sugerencias del propio Papa, el programa de la Signatura siguió fundamentalmente planteamientos y esquemas proporcionado por Pietro Bembo, mentor cualificadísimo que no precisa prentación alguna, ni calificativo o precisión. No obstante, y a renglón seguido, es necesario hacer constar que no debemos minusvalorar aportes del propio Rafael desde una óptica históricoliteraria; podría sustentar esta idea la aceptación positiva y las relaciones óptimas del Urbinate desde su llegada a Roma, con el elitista contexto literario de las cortes pontificias de Julio II y, sobre todo, de León X, exigentes a ultranza, imbuidas del conocimiento y saberes de la Antigüedad e incluso calificables en ocasiones de un excesivo espíritu cultista.

Lugar de espera de la audiencia papal entonces para emabajadores y delegados, la Estancia de Heliodoro glosa, en la bóveda, la protección de Dios al pueblo elegido y referidos a su Iglesia a través de los tiempos en los inferiores frescos parietales, resaltando a San Pedro, primer papa y su fundamento, su inviolabilidad y por extensión de los Estados Pontificios. En la Estancia del Incendio del Borgo, se conservaron los frescos de su bóveda, con escenas religiosas anteriores pintadas por Perugino; los rafaelescos frescos parietales atienden a hechos relevantes y de algún modo sancionados por la divinidad, de papas de nombre León, aquí invariablemente con los rasgos de León X, destacando en su intención el que alude a la justificación del pontífice sólo ante Dios. La Sala de Constantino, que no ha conservado su techumbre lígnea original, narra los hechos claves de este Emperador conducentes al reconocimiento del Cristianismo, concluyendo con el espinosa cuestión, jurídicamente ya negada, de la donación constantiniana al papado de la ciudad de Roma ${ }^{13}$.

13 Vid. Rafael. Catálogo completo de pinturas. Madrid, Akal, $1992\left(1^{\mathrm{a}}\right.$ ed. Raffaello. Florencia, Cantini, 1989), con mucho el esmerado catálogo de obras de Maria Antonietta Zancan; no así la introducción de Sylvia Ferino Pagden, escasísima, reductiva en exceso y como de puro compromiso; asimismo, vid. GONZÁLEZ RODRÍGUEZ, Antonio: Rafael, "El Arte y sus Creadores", nº 8. Madrid, Historia 16, 1993. 
Por su parte, en la Estancia de la Signatura lo que se plantean son tres conceptos universales: Verdad, en sus dos acepciones de verdad revelada y verdad racional, Belleza y Bien, tal como entonces eran entendidos y explicitados en dos niveles; uno superior al tiempo religioso y ámbito de las Ideas, donde sólo caben alegorías abstractas y poco más, que se plasman en la bóveda. Su consecuencia y ejemplificación, se desarrollan en una serie de frescos parietales, a un nivel inferior de la Estancia, mediante historias en una dimensión densamente humanista. Así, en general, no es el programa tradicional de una biblioteca, al que sólo en parte se adecúa, sino que, como ha demostrado Chastel, es bastante más amplio, ambicioso y de intención más universalista que, en modo alguno, asume componentes escolásticos, como alguna vez se ha señalado. En efecto, el rango asignado a los tres conceptos básicos es semejante y sin subordinación de ningún tipo, y cualquier referencia a principios universales queda al margen del programa. Verdaderamente se trata de un auténtico Speculum Doctrinae, según los tres ejes reseñados.

Ante todo en esta Estancia de la Signatura, es notoria la facilidad y eficacia pasmosas de Rafael para traducir a imágenes los conceptos que integran el programa; es mérito y aportación suya y sólo suya, que de modo inmediato caló en Julio II. Lo hace, además, como Vasari reseña, de manera sencilla, con gestos elegantes, nada afectados y plenos de belleza y gracia, cualidades estéticas quasi innatas en el Urbinate, que asimismo constantemente apunta el aretino en su biografía. Pero no conviene engañarse al respecto, un abrumador trabajo previo cifrado en diseños y estudios de modelos del natural y sus actitudes, está en la base de todo ello, aunque no es menos cierto que muchos rasguños mínimos ya tienen el germen de esas gracia y belleza $^{14} \tan$ ponderadas por Vasari. Por otro lado, la serie de bocetos, propuestas y dibujos preparatorios conservados para esta Estancia, con variantes y datos que no pasaron finalmente a las pinturas, denotan una larga elaboración por parte de Rafael, constante en su labor como quedó señalado, y una personal meditación sobre un programa genérico y abierto.

Asimismo es la Estancia de la Signatura un relevante y significativo capítulo, que afectaba entonces a todas las esferas del conocimiento humano y en este irrepetible contexto de Roma durante las dos primeras décadas del Cinquecento, de la entonces denominada Concordatio entre culturas pagana y cristiana. En efecto, se trata de un paradigmático exponente del contexto cultural de la corte pontificia que entonces se adueñaba de un ya operante "mito del rinascere all'antico", tras las experiencias, intentos y logros del Quattrocento, singularmente la decisiva aportación albertiana ${ }^{15}$; se aspiraba a un orden universal que fuera expresión de la plenitudo temporum que se

14 Esta plasmación del nacimiento de la Idea del Bello desde unos trazos apenas esbozados, el que escribe, sólo los ha visto y percibido en Rafael, Parmigianino y Annibale Carracci.

15 Aportación en su más amplio sentido culturalmente hablando y según el referente del legado de la Antigüedad como modelo a seguir; lui geometra, lui astrologo, lui musico, según sentencia de Cristoforo Landino, c. 1475; Alberti es ante todo sinónimo de cultura arquitectónica y reivindicador de la condición intelectual del arquitecto, que en su concepción debe tener en la ciudad un papel de primer orden, ser un auténtico arquitecto-filósofo (pensaba sin ambages en sí mismo). Su aportación fue clave asimismo en pintura (De pictura, 1435; Della pittura, 1436; Elementa picture, 1435-1436; De punctis et lineis apud pictores, 1448) e incluso para la escultura con su De statua, c. 1460. 
tenía la convicción de estar viviendo, entendida como una renovatio del mundo bajo el signo de la Iglesia y con centro en Roma, la Urbs devuelta a su esplendor imperial. Sueño ${ }^{16}$ que tuvo una de sus mejores expresiones en esta Estancia de la Signatura y que las Tesis de Wittenberg de 1517 ahogarán sin remisión.

\section{Signatura, bóveda}

A pesar de lo afirmado por Vasari -tirar por tierra todo lo hecho- buena parte de las pinturas de la bóveda, al parecer, corresponden a los trabajos prerrafaelescos, de Sodoma con toda probabilidad. Fingidas molduras arquitectónicas y frisos decorativos de elementos geométricos y grutescos compartimentan el espacio en secciones simétricamente dispuestas en torno a un octógono central planteado ilusionísticamente, a cielo abierto ${ }^{17}$, con una serie de putti que sostienen el escudo papal. Éste, los cuatro tondi de las alegorías (Teología, Filosofía, Poesía y Justicia) y las "escenas primigenias" ad hoc, son concordantemente atribuidas a Rafael; se presentan como cuadros acoplados al techo y fijados cada uno, mediante cuatro ornamentados tachones dora$\operatorname{dos}^{18}$; las pinturas correspondientes fingen por su parte fondos de sugestivas teselas de un dorado mosaico.

Entre los señalados, se disponen otros espacios menores, siempre con encuadres de fingido mármol, cuatro trapezoidales de lados mayores curvos, con dos escenas cada uno y ocho trianguliformes con el roble o la quercia sobre fondo azul ${ }^{19}$, emblema familiar de Julio II, que asimismo aparece en las cuatro pechinas. Las citadas escenas duplas, una en grisalla basada en Tito Livio y otra polícroma de tema mitológico inspirado en Higinio ${ }^{20}$, por cada compartimento, no sólo hacen hincapié en la latinidad como cultura -cuestión que ahora, a inicios del Cinquecento, se va imponiendo en la corte papal- sino que aseguran una correspondencia entre las citadas alegorías con

${ }^{16}$ Ideal de Julio II de ser un nuevo César con la Iglesia Universal como su Imperio; fue leit-motiv de sus principales proyectos artísticos: la bóveda de la Sixtina y las Estancias Vaticanas -muy en concreto ésta de la Signatura- pero cara al resto de la ciudad y del orbe, aún más importante, clave y primordial, la construcción de la nueva basílica de San Pedro del Vaticano, como epicentro, foco y núcleo de todo, ya iniciada por Bramante desde 1506, vid. SUÁREZ QUEVEDO, Diego: "En las entrañas de la tierra: primera piedra de la Basílica de San Pedro del Vaticano" (pp. 357-360), en "Varia: Centenarios, 15062006" (pp. 355-373), Anales de Historia del Arte, n 16 (2006).

${ }^{17}$ La referencia es usualmente al óculo de la Camera Picta, 1465-1474, de Andrea Mantegna en el palacio de los Gonzaga en Mantua; no conviene olvidar, no obstante, la decoración pictórica que, entre 1488 y 1490, realizara el propio Mantegna en la desaparecida capilla del Belvedere de Inocencio VIII.

18 Otra suerte de ilusionismo, que utilizará Rafael tanto en la bóveda de la Estancia de Heliodoro como en la citada Loggia de Psique en la Farnesina, imitando tapices fijados a la bóveda. Cada tondo tiene un diámetro de $180 \mathrm{~cm}$.; similar medida tiene el octógono central, en tanto que cada trapezoide es de unos 120 X $105 \mathrm{~cm}$.

19 En general, la crítica asigna estos recuadros menores a labores previas a Rafael.

20 Tito Livio (59 a. C.-17 d. C.), paduano de origen y en Roma desde los veinticuatro años, fue el insigne historiador de Octavio Augusto, como bien es sabido; Cayo Julio Higinio (64 a. C.-17 d. C.), de posible origen hispano fue liberto por Augusto y a su cargo quedó la Biblioteca Palatina; Astronomía poética y Fábulas, fueron sus más importantes obras. Por tanto, mundo griego sí pero se da una constante afirmación y diferenciación de la latinidad; éste es un dato, y no el único. 


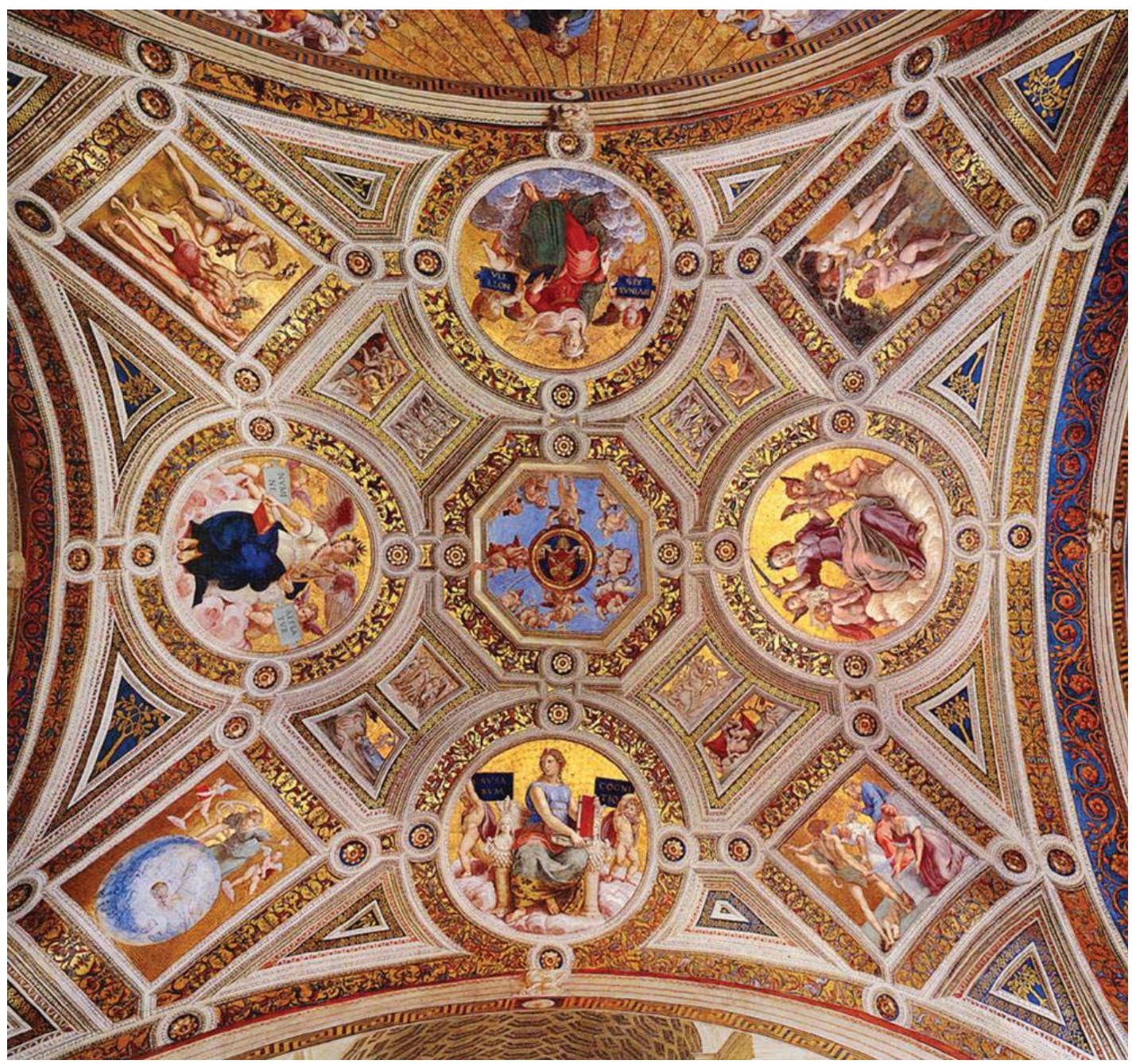

Fig. 1. Estancia de la Signatura, bóveda.

los cuatro elementos del mundo antiguo, según la equivalencia siguiente: TeologíaFuego; Filosofía-Agua; Poesía-Aire y Justicia-Tierra ${ }^{21}$.

La alegoría de La Teología, es una figura femenina con velo blanco, manto verde y túnica roja, que son los colores asignados por la liturgia a las virtudes teologales $(\mathrm{Fe}$,

21 Cuatro putti, además, a manera de geniecillos asociados a los cuatro elementos, quedan dispuestos en la bóveda justo encima de cada fresco parietal, incidiendo en la citada equivalencia; los correspondientes a la Teología y a la Filosofía finalmente no coinciden. Seguramente hubieron cambios sobre la marcha de los cuales, en realidad, no hay constancia. ¿Asignar las paredes con mayor superficie a pintar a la Disputa y a la Escuela de Atenas? ¿El deseo del Papa imponiendo al Parnaso su ubicación?; cuestiones no previstas, teniendo en cuenta que estos putti eran parte de lo mantenido de las labores previas. Con toda probabilidad, esto ha incidido en la propuesta (STRINATI, Claudio, op.cit., pp. 2829) de asociar la "Tentazione di Eva (immagine per eccellenza della perdita della conoscenza offerta dall'Albero della Vita e quindi della prima filosofia)" y, por tanto, ligada a la Escuela de Atenas, que no deja de ser una hipótesis un tanto rebuscada cuando, además, el episidio de Adán y Eva queda entre la Disputa y el Luneto de las Virtudes; del mismo modo, se hace la asociación de "la scene del Motore immobile che regola l'universo (l'elemento teologale per antonomasia)" con la Teología, pues, y detonante de la Disputa; el Primer Movimiento o la Astronomía, por su parte, se sitúa entre la Escuela de Atenas y el Parnaso. 
Esperanza y Caridad); queda flanqueada por dos putti que portan sendas cartelas con el texto DIVINAR[um] RER[um], izquierda; NOTITIA, derecha. Personifica la Verdad Revelada.

La Filosofia queda representada mediante una figura femenina de vestimenta con los colores de los cuatro elementos (azul claro o celeste, rojo, verde y amarillo verdoso); aparece sentada en un trono con imágenes de la Artemisia de Éfeso, que simbolizan la fecundidad de la naturaleza. Porta dos libros (Moralis y Naturalis) y, asimismo, es acompañada de sendos putti con cartelas que proclaman las CAVSAR$V M$, izquierda y COGNITIO, derecha; las causas últimas como esencia y motivo del estudio de la filosofía. Personifica la Verdad Racional.

La Poesía, considerada entonces la máxima expresión de venustas, es una figura femenina coronada de laurel, alas desplegadas y portando un libro y una lira. Las cartelas de los correspondientes putti contienen la sentencia virgiliana (Eneida): $N V$ MINE, izquierda; AFFLATVR, derecha. Personifica la Belleza.

Como personificación del Bien, está La Justicia, figura femenina con espada y balanza; son ahora cuatro los putti que la acompañan, dos por cada lado, con cartelas que contienen un texto jurídico de Justiniano: IVS SVVM, izquierda; VNICVIQVE TRIBVIT, derecha.

Las cuatro "escenas primigenias" -es un modo de denominarlas; podría ser "detonantes claves" o "hitos significativos"- en relación precisa con cada una de las alegorías comentadas y, de alguna manera, definitorias de las mismas, son las siguientes.

Adán y Eva o El Pecado Original, de figuras con notorias referencias clasicistas y, en el caso del desnudo de Eva, asimismo de morbidez y sfumature leonardescas. La idea es la presencia y explicitación de la felix culpa, que fue causa de la venida al mundo del Redentor. Su relación es con La Teología, y sobre el fresco de La Disputa como su consecuencia y ejemplificación.

El Primer Movimiento o La Astronomía, entendida bien como alegoría del principio del universo, bien como la ciencia astronómica en actitud de contemplar la Tierra. Su relación es con el tondo de La Filosofía y sobre la inferior pintura de La Escuela de Atenas.

El mítico episodio de Apolo y Marsias, desafío de un humano a todo un dios y el funesto resultado de victoria de éste y ser desollado aquél, es acaso la escena más interesante. En efecto, a partir de un motivo pitagórico que está también presente en Dante (Paraíso, I, 19 y 21), los neoplatónicos florentinos con Marsilio Ficino a la cabeza y con él toda la Accademia de Careggi, atribuían a este episodio de gara entre Apolo y Marsias, una especial consideración y un muy concreto y paradigmático valor simbólico, algo que Rafael asumió durante su estancia florentina. A saber, la victoria de la armonía divina sobre las pasiones humanas; a superar las ataduras humanas cifradas en la piel que se arranca al osado Marsias, pasadas a claves espirituales o intelectuales. La relación de este episodio es con la alegoría de La Poesía, a su vez la forma más perfecta y el estadio más alto de belleza en una dimensión neoplatónica, y por tanto La BELLEZA con mayúsculas, sobre el fresco de El Parnaso flanqueado por dos escenas consiguientes en grisallas.

El Juicio de Salomón, aquí incluido como "el juicio de los juicios", presenta aún más evidentes similitudes y recuerdos de la estatuaria antigua; la figura del verdugo 
ha sido relacionada incluso con uno de los Dióscuros de Monte Cavallo del Quirinale romano. Su conexión es con la alegoría de La Justicia y sobre el denominado Luneto de las Virtudes del nivel inferior de la Estancia, así como de sus escenas complementarias.

\section{Signatura, frescos parietales}

Los frescos parietales quedan planteados mediante fingido marco arquitectónico que actúa como efectiva apertura y reclamo de la historia que, a ojos del espectador, se "abre" de este modo en cada una de las paredes. Sobre pequeños pilares de frentes decorados con llamativos grutescos, en grisalla y dorado, sobre fondo azul, salta un arco de medio punto doblado, cuyo intradós es recorrido por llamativas grecas, de nuevo doradas, sobre fondo negro.

Son pinturas de considerables dimensiones ${ }^{22}$ que, prácticamente, ocupan todos los alzados correspondientes, y que van acomodándose a las irregularidades de la propia Estancia, puertas y ventanas preexistentes irregularmente dispuestas; aspectos que Rafael va solventando y resolviendo en pro de una coherente simetría.

Pero es en las dimensiones globales de la propia Estancia, en las que aquí es preciso incidir, cuestión no suficientemente destacada a menudo. Es relativamente pequeña, unos ocho por diez metros ${ }^{23}$, y por consiguiente, es, de nuevo, otro factor con el que hubo de contar el Urbinate; reto que asimismo solucionó con éxito, adecuando la visión al respecto, cuidando mucho las escalas y potenciando, en fuga armónica y ponderada, la profundidad. En suma, planteando mensurables espacios convenientes y proporcionados en los que acomodar las figuras, asimismo proporcionalmemte dispuestas; ello es claro y es una cuestión de la que se parte y excelentemente resuelta en todos los casos, pero no es el fin conformar un espacio geométrico, sino el ámbito adecuado, y donde la luz juega un papel de primer orden, en que desarrollar las historias que avalen y sean ejemplares consecuencias de lo planteado en la bóveda, es decir, que sean los perfectos, amplios, sugestivos y diversos integrantes del aludido Speculum Doctrinae.

\section{La Disputa}

La Disputa del Santísimo Sacramento, La Disputa del Sacramento o simplemente La Disputa, son las denominaciones al uso, ciertamente un tanto anacrónicas ${ }^{24}$ pero

${ }^{22}$ No resulta fácil curiosamente hacerse con las dimensiones completas en esta Estancia; la Disputa y la Escuela de Atenas, tienen de base $770 \mathrm{~cm}$; el Parnaso, $670 \mathrm{~cm}$. y el llamado Luneto de las Virtudes, $185 \mathrm{~cm}$.; arcos de medio punto, a tutto sesto prácticamente, en los tres primeros y muy rebajado en el último.

${ }^{23}$ Ancho y largo, se entiende; altura relativamente considerable, en cambio, probablemente de unos 6-7 metros.

${ }^{24}$ Anacronismo total, incluso si es "sobre", como alguna vez aparece en italiano (Disputa sul Sacramento) y, tal como reza el texto de Vasari, también lo era en el Seicento, que es cuando surge, al 


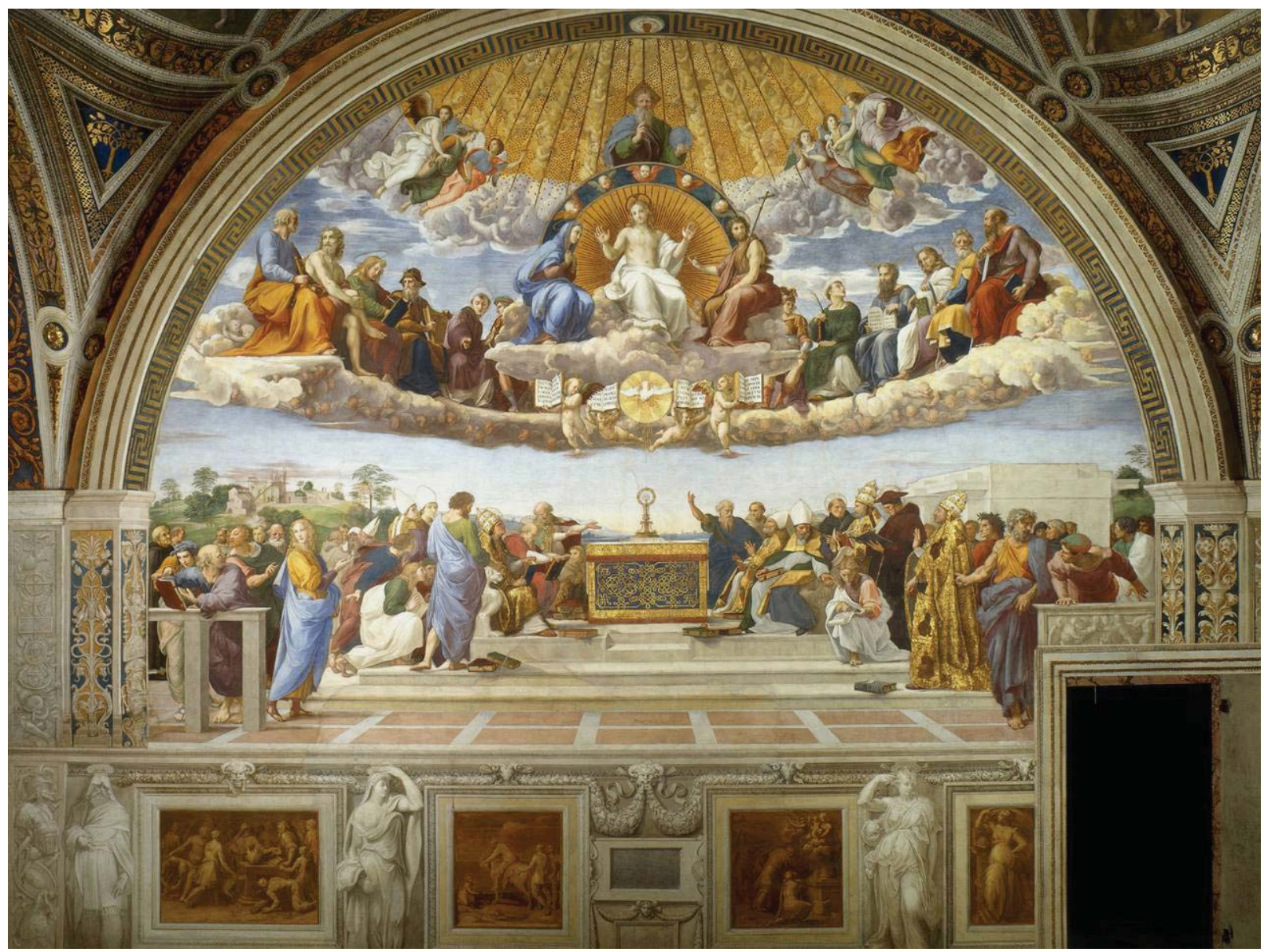

Fig. 2. Estancia de la Signatura, Disputa.

ya generalizadas, de este fresco parietal de la Signatura, al parecer, el primero que Rafael ejecutara; acaso más verosímil sería, como ha sido propuesto, llamarle Triunfo de la Eucaristía o Triunfo de la Iglesia.

Vale la pena -y hacerlo aquí- dejar "hablar" al propio Vasari al respecto, según su comentario que, salvo algún matiz de redacción, es similar en ambas ediciones, 1550 y 1568, de sus Vite, pues a partir de aquí deviene la denominación de esta historia de la Signatura.

(...) e sopra l'Ostia, che è sullo altare, disputano (...). Avvenga che Raffaello ebbe questo dono dalla natura di far l'arie sue delle teste dolcissime e graziosissime, come ancora ne fa fede la Nostra Donna che messesi le mani al petto, guardando e contemplando il Figliuolo, pare che non possa dinegar grazia; senza che egli riservò un decoro certo bellissimo, mostrando nell'arie de' Santi Patriarci l'antichità, negli Apostoli la semplicità e ne'Martiri la fede.

Ma molto più arte et ingegno mostrò ne 'santi Dottori cristiani, i quali a sei, a tre, a due disputando per la storia, si vede cere loro una certa curiosità et uno affanno nel

parecer, la mala interpretación o tergiversación de lo comentado por el aretino; por cierto que este fresco es el penúltimo al que alude, tras La Escuela de Atenas, donde asimismo repite varias veces el disputar de sus protagonistas y de El Parnaso. 


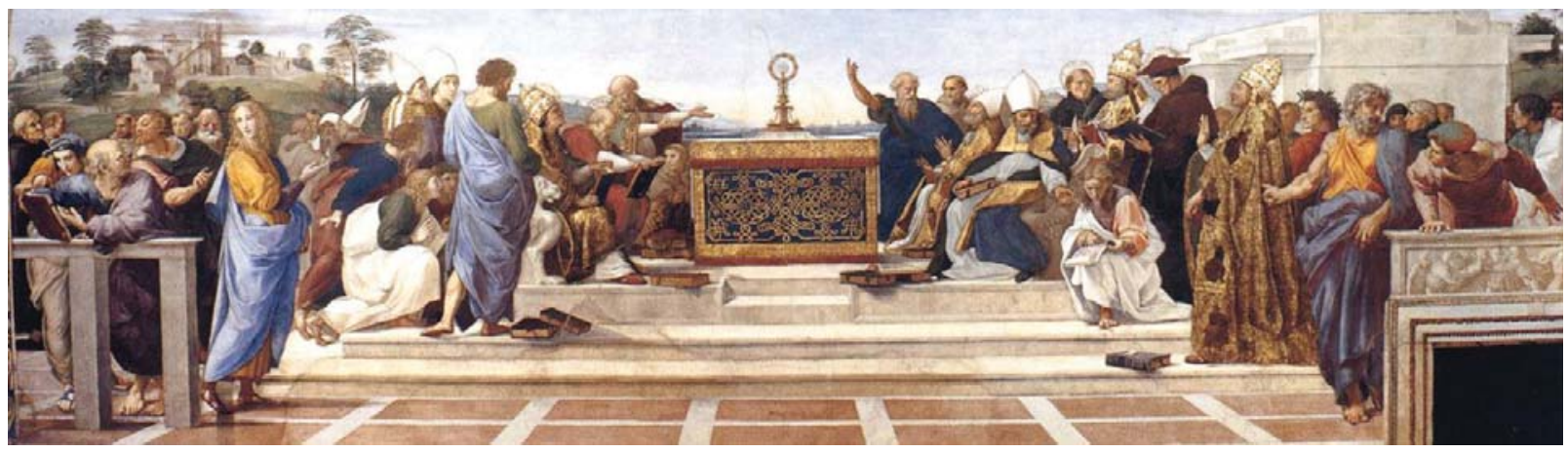

Fig. 3. Disputa, detalle.

voler trovare il certo di quel che stanno in dubbio, faccendone segno col disputar con le mani e col far certi atti con la persona, con attenzione degli orecchi, con lo increspare delle ciglia e con lo stupire in molte diverse maniere, certo variate e proprie (... $)^{25}$.

Se trata de la historia que, en un nivel inferior, explicita el binomio formado por Adán y Eva o El Pecado Original y la Teología, dispuestos en la bóveda.

Punto focal, visual y de referencia perspectívica de toda la amplia composición es la Hostia consagrada, que se eleva desde el ostensorio situado sobre un ara o mesa de altar; de este modo, la Eucaristía, sacramento cristiano ${ }^{26}$ por excelencia, se presenta como nexo de unión entre cielo y tierra y es, a su vez centro de la Iglesia tal como aquí debe quedar plasmada. Iglesia entendida no como edificio o templo que, por extensión, es de uso común, sino como las dos asambleas -concilios, cabría decir- de la iglesia triunfante, parte superior, e iglesia militante, parte inferior; ésta sobre una suerte de explanada o proscenio del que sólo se plasma su solería y unas gradas de acceso a la citada ara, la triunfante sobre nubes lieralmente cuajadas de angelillos. Interesa no explicitar ningún tipo de construcción o espacio arquitectónico que, en cualquier caso, sería incidir en particularidades.

${ }^{25}$ Cita efectuda a partir de Le vite de 'piú eccellenti architetti, pittori, et scultori italiani, da Cimabue insino a'tempi nostri. Nell'edizione per i tipi di Lorenzo Torrentino. Firenze, 1550. A cura di Luciano Bellosi e Aldo Rossi. Presentazione di Giovanni Previtali; 2 vols. Turín, Einaudi, 1991, volume secondo, pp. 619-620; excelente edición, sobre la que fue hecha la no tan afortunada ni cuidada traducción española de Cátedra, 2002 y reeds., esto por lo que se refiere a traducciones completas; son varias las antologías en español, con mucho la más rigurosa, creo, es Las vidas de los más excelentes arquitectos, pintores y escultores italianos desde Cimabue a nuestros tiempos (Antología). Estudio, selección y traducción de María Teresa Méndez Baiges y Juan Ma . Montijano García.Madrid, Tecnos, 1998 y reeds.; asimismo sobre las Vite, 1550, Por cierto que el párrafo conclusivo, in molte diverse maniere, certo variate e proprie, añadiéndole la recomendación de diversas edades, es prácticamente la definición albertiana de Pintura de Historia, con todo el rango que Battista le asignaba y, curiosamente, hecha por Vasari que si en las Vite, 1550, consideraba a Alberti como el Vitruvio florentino, en las Vite, 1568, ya no lo es, y sí se muestra significativamente crítico, en varios pasajes de su biografía. Corresponde al Primo Volume della Terza Parte, Florencia, appresso i Giunti, 1568, como quedará reseñado más adelante.

${ }^{26}$ Es preferible aún, aludir sólo a "sacramento cristiano"; tras la ruptura protestante posterior, será una de sus negaciones claves. 
Quedan planteados así dos hemiciclos paralelos y uno sobre otro, como auténticas "arquitecturas de figuras", en lo alto una serie de profetas, apóstoles y santos ${ }^{27}$, abajo pontífices, doctores de la iglesia y fieles. Un marcado eje vertical hace las veces de perno central que conecta, con la citada Hostia como punto medio donde se inserta la paloma del Espíritu Santo, el ara inferior y las tres personas de la Trinidad, con el Padre Eterno entre coros angelicales que, en la cúspide, bendice con su mano diestra y con la izquierda sostiene un globo cristalino del Universo; inmediatamente debajo la Deesis, Cristo -como Varón de Dolores- flanqueado por la Virgen y San Juan Bautista, en una gran aureola semicircular con cabezas de querubines. Bajo ésta y a ambos lados de la Hostia, son mostrados como libros abiertos los cuatro Evangelios.

El propicio fondo dorado, sinónimo de divinidad, para la figura de la primera persona de la Trinidad, queda acentuado mediante un haz de rayos resaltados en estuco, al parecer según tradición umbra, en que se inscriben figurillas angelicales; nubes naturales y asimismo con ángeles, se plantean como transición al nivel inferior con la iglesia triunfante. Ésta desarrolla, amplifica y supera lo que el propio Rafael realizara en su fresco, 1505, para la iglesia del monasterio de San Severo en Perugia que, a su vez, tomaba datos del Juicio Final, 1499, fresco de Fra Bartolomeo della Porta pintado para la capilla Dini en el cementerio anexo al hospital florentino de Santa Maria Nuova y hoy, muy deteriorado, en el museo de San Marcos de Florencia.

A tenor de los varios bocetos y dibujos preliminares conservados ${ }^{28}$, la invención y estructuración fueron objeto de un calculado proceso de depuración y simplificación, bajo estrictos criterios geométricos y proporcionales en función de la claridad de la visión y de la captación inmediata de la esencia de la historia pintada; no debía caber posibilidad alguna de duda, de ningún tipo. Cada figura, cada detalle, aparece subordinado al conjunto mediante sabias disposiciones, compensadas simetrías y pautadas relaciones, con los intervalos precisos de netos y vacíos, todo configurando un universo espiritual jerárquicamente ordenado, que no excluyen variaciones en gestos y movimientos, como precisaba Vasari, bajo un preciso control perspectívico.

Pierluigi De Vecchi supo expresar, magistralmente en mi opinión, ese mayor arte e ingenio rafaelescos que Vasari otorgaba a los santos doctores cristianos, al precisar que la solemne arquitectura humana de La Disputa, se hace así visible manifestación de la Civitas Dei en presencia de los fundadores divinos y humanos de la Iglesia. Tan a propósito resulta la afirmación que invitan a un complemento, que creo lícito hacer.

Total sentido de ciudad con un proscenio-plaza de carácter sacro, logrado al orillar a los integrantes de esa iglesia militante, de modo aparentemente fácil y natural, y que, con apoyo en las líneas de fuga de la solería y el reclamo de las escalinatas del ara, además de gestos e indicaciones de los personajes, hacen que la visión se focalice -y llegue armónicamente conducida- en el correspondiente frontal de altar.

${ }^{27}$ Como integrantes de la iglesia triunfante y situados un tanto más bajas que las figuras de la Deesis, a la izquierda han sido identificados San Pedro, Adán, San Juan Evangelista, David, San Esteban y Jeremías; a la derecha Judas Macabeo, San Lorenzo, Moisés, San Mateo (o Santiago el Mayor, o Santiago el Menor), Abraham y San Pablo. En ambos casos, desde los extremos hacia el centro.

${ }^{28}$ Desde el estatismo primigenio (Ashmolean Museum de Oxford), pasando por una mayor relación composicional (Musée Condé, Chantilly), hasta el más cercano al planteamiento definitivo (British Museum, Londres), además de figuras individuales (Musée Wicar, Lille y Musée Frabre, Montpellier). 

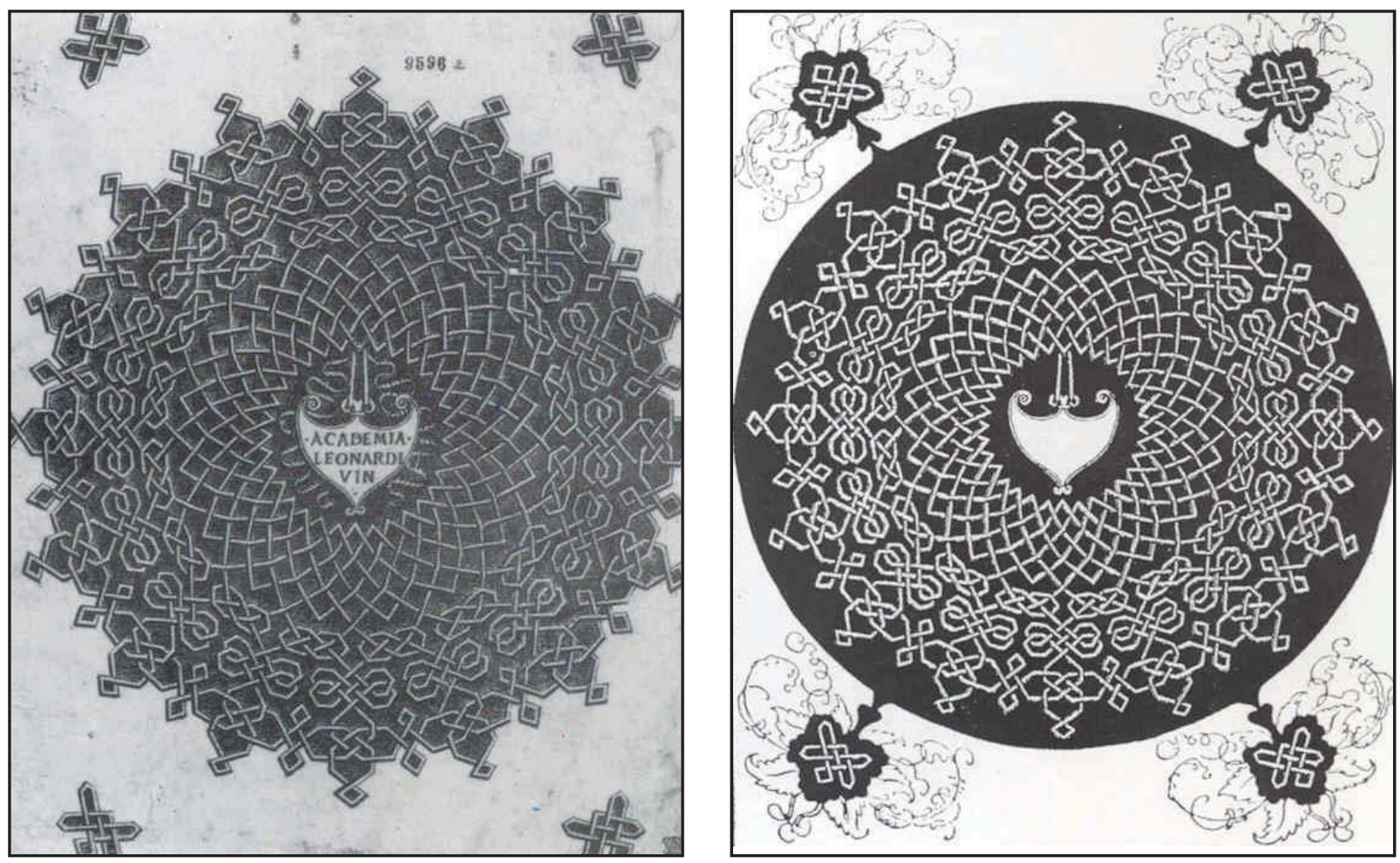

Fig. 4. Grabado (c. 1495) de la Accademia, basado en los nodi vinciani. Biblioteca ambrosiana, Milán (izquierda). Grabado de Durero, sin la referencia vinciana (derecha).

En efecto, este frontal de altar constituye, por parte de Rafael, una sutil cita y un claro homenaje a Leonardo que, mediante las forme intrecciate o nodi vinciani, había elaborado durante los años de su primera estancia milanesa, uno de los emblemas de la Accademia Vinciana, tal como fueron grabados a partir de dibujos como los nodi vinciani del Codice Atlantico, acaso modelos para pavimentos pero más propiamente ludi simbolici, dentro de una concepción de las formas como matrices universales ${ }^{29}$

Sólo algunos personajes de la zona terrestre han sido identifacados, de modo más o menos válido ${ }^{30}$; interesa referenciar aquí la presencia de algunos. Del lado izquierdo, el beato Angelico con hábito dominico; Donato Bramante, en primerísimo plano, apoyado en una balaustrada y girándose hacia un desconocido, señala e indica algo sobre el libro que sostiene; con casi total certeza, Francesco Maria della Rovere, el joven que, volviéndose hacia el espectador, señala la mesa de altar (figura marcadamente leonardesca, ante todo en la mímica precisa del citado gesto; visualmente conecta con una figura de espaldas, destacada y plásticamente miguelangelesca; todo en una ordenada sucesión hacia el ara); San Gregorio Magno sentado, con el Liber Moralium y los rasgos de Julio II.

29 Codice Atlantico, fols. 700 recto y 701 recto; vid. LAURENZA, Domenico: "IV.4. Le forme come matrici universali", en La mente di Leonardo [Nel laboratorio del Genio Universale], a cura di Paolo Galluzzi. Florencia, Giunti, 2006, p.193.

30 A la izquierda, junto a San Gregorio Magno-Julio II, San Jerónimo, un anciano que lee junto al león; a la derecha, San Ambrosio y junto a él, un obispo sedente que es San Agustín; tras éste Santo Tomás de Aquino, el papa Inocencio III y San Buenaventura. 
Del lado derecho, y muy destacado, revestido con pluvial dorado y con el tratado De sanguine Christi a los pies, Sixto IV (Della Rovere, tío de Julio II), aparece erguido en la primera grada, tiene a Dante a su espalda y, más atrás, semioculto por un capuchón negro, se reconoce a Savonarola.

La presencia de un vano efectivo de la Estancia ${ }^{31}$, a la derecha, queda compensado y simétricamente equilibrado, de modo ágil y sencillo, mediante la balaustrada en que se apoya Bramante a la izquierda.

El gran bloque marmóreo del fondo a la derecha, quiere ser la piedra y fundamento de la Iglesia como institución fundada por Cristo, del mismo modo que piedra angular de la misma fue San Pedro primer Papa, pero además debe aludir a las obras de la nueva basílica vaticana, entonces ya en construcción por iniciativa de Julio II y fundamental proyecto de Bramante, presente en el fresco, como queda dicho; precisamente al fondo del lado izquierdo y tras la figura del arquitecto, como corroborando esta idea, se hace una referencia mínima a un hecho constructivo.

En esta línea, la presencia de Angelico, pintor y sobre todo de Bramante, arquitecto, constituyen sendos datos a tener en cuenta, en relación con la dignidad del arte y su consideración de disciplina intelectual, cuestión que, de modo inmediato, hará patente Rafael en su Escuela de Atenas.

\section{La Escuela de Atenas}

Fresco pintado en la pared frente a la Disputa o exaltación de la Verdad Revelada, en igualdad y a su mismo nivel, que ha adoptado este significativo y elocuente nombre de Escuela de Atenas, celebra la investigación racional de la Verdad; se trata acaso de la obra más divulgada, reproducida y recurrente del Urbinate, pero no por ello la más conocida en todas sus dimensiones y en toda su integridad. La conjunción de $E l$ Primer Movimiento o La Astronomía y La Filosofía, es su detonante desde la boveda.

La gran asamblea de filósofos y sabios de la Antigüedad, solos o con sus respectivos acólitos, alumnos, "escuelas o academias" u oyentes, quedan dispuestos en el interior de un edificio -ahora sí interesa defininar y precisar un espacio arquitectónico signado con el lenguaje del clasicismo- de modos y períodos solemnes y grandiosos ${ }^{32}$ que, en determinadas formas, como la articulación mediante dobles pilastras de orden gigante, probablemente son deudoras de Bramante y su proyecto para la basílica del nuevo San Pedro; para mí tengo por cierto y muy claro, que lo que prentende, y desde luego logra, Rafael, es precisamente citar clara y contundentemente este edificio, planteado como el primero de la Catolicidad que, no conviene olvidarlo, se entendía

${ }^{31}$ Sobre este vano, un alto murete de fingido mármol, permite a un personaje, pendant de Bramante, apoyarse, girarse y proyectarse hacia el espacio real, "invadiéndolo" casi; al mismo pertenece el hermoso dibujo preparatorio del Musée Fabre de Montpellier, ya citado.

${ }^{32}$ A menudo, se dice que tiene ecos de la arquitectura romana tardoimperial, lo cual resulta válido, a mi modo de ver, aclarando que es a nivel de temática espacial, pero aclararía más la intención y base al respecto, que se pretende expresar la idea, tanto de Julio II como de Bramante, en relación a la empresa de San Pedro, siendo conscientes ambos de no tener posibilidad vital de ver las obras concluidas, de proyectarla a una escala aún más grandiosa. 


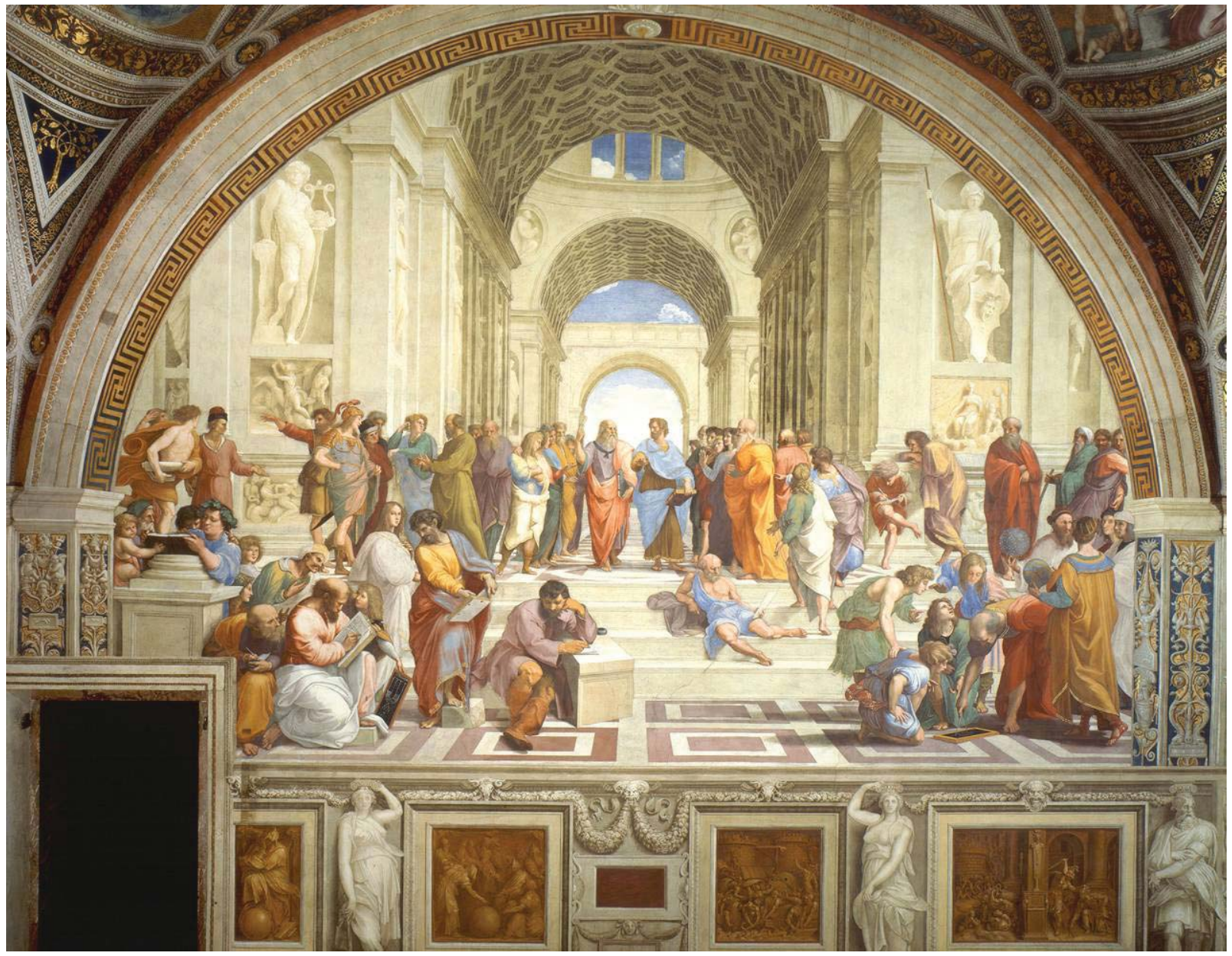

Fig. 5. Estancia de la Signatura. Escuela de Atenas.

entonces, y tal era el ideal de Julio II, como un "nuevo imperio universal presidido por la Iglesia con centro en este templo".

El empeño vasariano de hacer a Bramante el autor del diseño para su paisano, no sólo resulta lesivo para Rafael y supone minusvalorar la inventiva del Urbinate, sino que ha conseguido hacer ver lo que no hay; esto es, respecto al proyecto bramantesco, ni es un edificio de planta central, ni existen chaflanes con dos hornacinas entre las dobles pilastras gigantes de articulación, leit-motiv del alzado interior de San Pedro y es, ademas, todo un planteamiento que remite a estructuras arquitectónicas efímeras y/ o celebrativas, muy en la línea en las que era un consumado experto Bastiano da Sangallo detto Aristotile, en las que Rafael pudo inspirarse y tomar como punto de partida para su propio diseño ${ }^{33}$.

Según estas bases, apoyos y referencias, es preciso ver este grandioso edificio como el Templo de la Sabiduría o de la Filosofía evocado por Marsilio Ficino, y como tal, inconcluso, lo cual se evidencia claramente; como receptáculo o continente del saber

${ }^{33}$ Así ha sido propuesto (vid. STRINATI, Claudio, op. cit., p. 30), lo cual presenta, pienso, bastante visos de congruencia y verosimilidad; a la sazón este Sangallo estante en Roma y que Rafael conocía y trataba desde su estancia en Florencia. 
racional, es algo siempre incompleto y a falta de sucesivas aportaciones humanas; en otras palabras, como el propio conocimiento humano, ha de ser un edificio non finito.

Como avales de verdad racional y en esta línea conceptual y cualitativa, en nichos a los lados del primer arco, se fingen las estatuas, totalmente convenientes, de Apolo y Minerva, ambas directamente referibles a modelos clasicistas; el significado y la razón de sus presencias se aclara un tanto en los pares de bajorrelives planteados bajo cada una de las mismas. Una lucha de personajes desnudos y un tritón que rapta a una nereida, simbolizan la violencia y las pasiones desatadas que dominan la parte inferior u oscura del alma o de la naturaleza humana, que deben ser dominadas, controladas, supeditadas y guiadas por la autoridad de la razón, representada por Apolo; menos descifrables son las escenas alegóricas representadas bajo Minerva, que parecen simbolizar la actitud de la inteligencia gobernada por esta divinidad. A ambos lados de éstos, se aprecian, en el proscenio, los inicios en sequencia de otras hornacinas y relieves semejantes. Otros nichos y relieves se entrevén en escorzo en las paredes de la nave hacia el fondo, con un propicio uso y control lumínicos.

Los medallones visibles de las pechinas de la cúpula representan, en fingido mármol, a una figura masculina que alza los ojos de un libro y a un personaje femenino que posa un brazo sobre un globo terrestre; tales gestos parecen ser un eco de los expresados por los dos personajes centrales, erguidos y en peripatética conversación en lo alto de la escalinata, Platón que lleva el Timeo, levanta un dedo hacia lo alto señalando el cielo -el ámbito de las Ideas- y Aristóteles que, con la Ética, adelanta un brazo con la palma de la mano vuelta hacia el suelo -sobre y hacia natura-. Con tan simples gestos, sintetizaba Rafael la esencia de sus respectivas doctrinas, según el procedimiento de concretar en imágenes sencillas las más complejas ideas, lo cual debió sorprender a sus contemporáneos, y a lo que Vasari parece aludir, afirmando que tal era su facilidad y prontitud al efecto en sus historias que competía con la eficacia de la palabra escrita.

El ojo del espectador, partiendo de la solería del proscenio, es sabiamente conducido a las escalinatas y de ahí a las figuras de Platón y Aristóteles, destacadas en alto y recortadas sobre el fondo a cielo abierto del último arco. Conforman el auténtico nudo y punto focal de la perspectiva, al tiempo que se presentan como núcleo de toda la composioción en tanto que representantes del saber de los saberes que la inteligencia humana ha generado; esto es, la FILOSOFÍA, así con mayúsculas, fruto de un fértil maridaje entre platonismo y aristotelismo.

Del resto de personajes, se ha identificado a Sócrates a la izquierda de las figuras centrales, conversando con un grupo de jóvenes entre los que están Alcibíades (o Alejandro Magno) armado, Jenofonte y Esquines (o Alcibíades); en el extremo izquierdo abajo, Zenón con un niño que sostiene un libro que lee Epicuro, coronado de pámpanos; Pitágoras, más a la derecha en primer plano, hace anotaciones en un grueso volumen, a partir de una tabla que le sostienen, Telange seguramente; tras él Averroes con turbante blanco se inclina hacia él. Heráclito, ensimismado y pensativo, apoya un codo sobre un gran bloque y hace ademán de anotar en un taccuino; Diógenes de Sínope o Cínico aparece literalmente echado sobre las escalinatas; el personaje en pie tras Heráclito que, mostrando un libro abierto, se vuelve hacia Pitágoras, ha sido identificado como Parménides (o Jenócrates o Aristoxeno). A la derecha, también en 


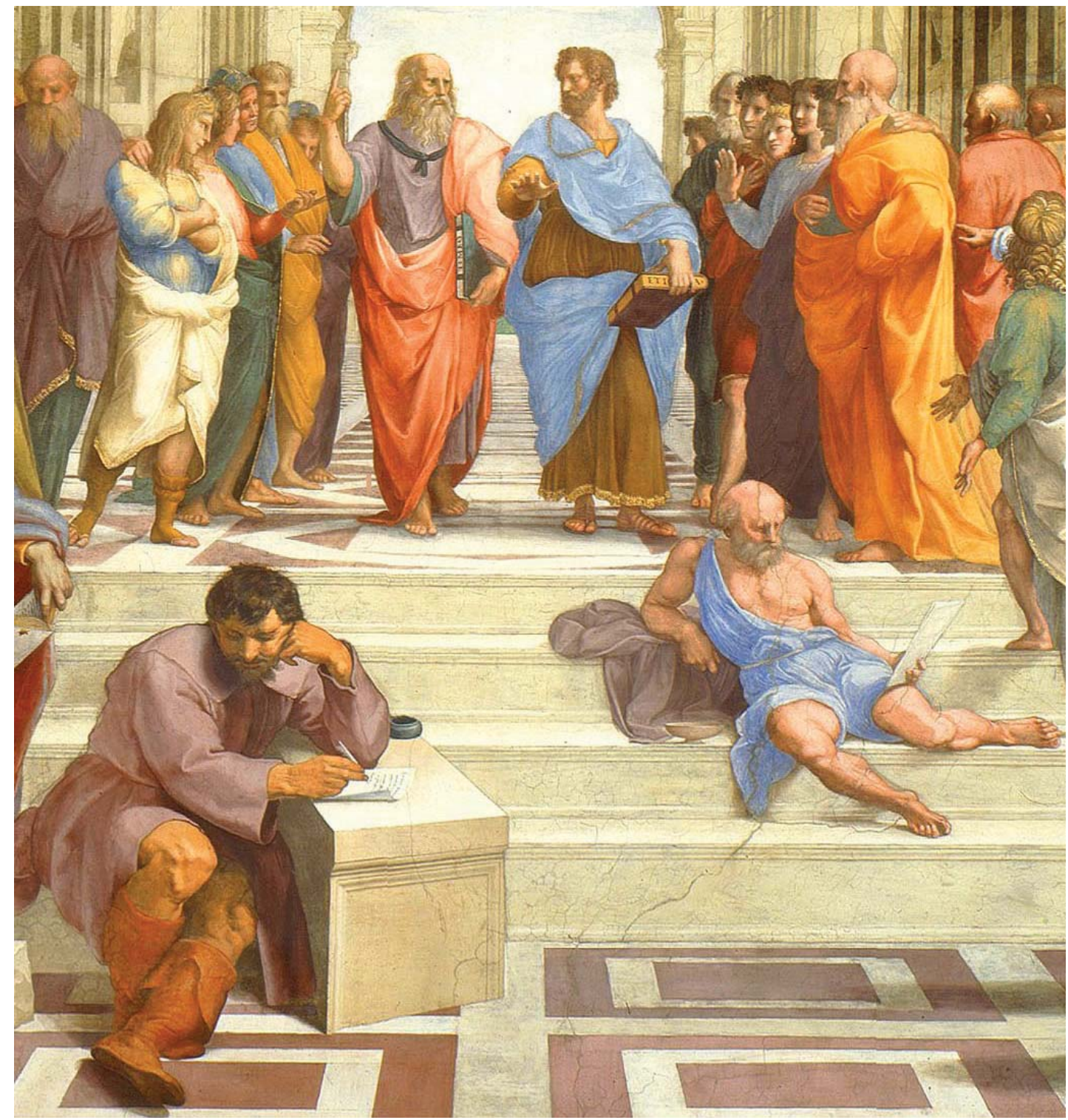

Fig. 6. Escuela de Atenas, detalle.

primer término, Euclides se inclina entre sus discípulos para medir con el compás una figura geométrica; tras él Zoroastro de frente y Ptolomeo de espaldas y con corona porque entonces se le confundía con un rey de esta dinastía egipcia; el primero con la esfera celeste mientras el segundo porta un globo terráqueo.

Estos "hombres ilustres" del pasado quedan estrechamente ligados al presente en una grandiosa perspectiva histórica, mediante correspondencias creadas entre los personajes de la Antigüedad y los contemporáneos del Urbinate, humanistas, literatos y miembros relevantes de la corte pontificia, pero asimismo cualificados representantes de las artes plásticas. Platón tiene los rasgos de Leonardo; Heráclito los de Miguel Ángel y Euclides los de Bramante, lo cual es todo un alegato y toma de postura, cifrado en imágenes-retratos, en pro de la dignidad y cualidad intelectual del arte.

Casi un niño, Federico Gonzaga, entonces huesped-rehén en la corte de Julio II, aparece tras Epicuro; de nuevo Francesco Maria della Rovere, el joven vestido de 
blanco tras el grupo de Pitágoras; identificaciones a tomar siempres con una cierta prevención. Zoroastro es tal vez Pietro Bembo; el mismo Rafael se ha autorretratado con berretto negro junto a Sodoma, entre el grupo de los astrónomos, como lo acostumbraban a hacer los más jóvenes que aún aprendían. Y Aristóteles, con muchos visos de verosimilitud, podría ser Bastiano da Sangallo, así llamado, Aristotile ${ }^{34}$.

Con los retratos de la Escuela de Atenas los artistas entran a formar parte de la superior asamblea de los doctos y las artes plásticas, antaño reducidas a maquinales, son elevadas al nivel de las artes liberales; importantísimo salto cualitativo desde la anterior consideración de mecánicas y artesanales. Rafael expresa de esta manera la concepción propiamente renacentista de la obra de arte, entendida como discurso mental no sólo traducción en forma visible, sino como búsqueda de la Idea.

Se ha visto en el fresco una representación de las siete artes liberales: en primer plano a la izquierda: Gramática, Aritmética y Música; a la derecha: Geometría y Astronomía. En lo alto de la escalinata: Retórica y Dialéctica. Los dos grupos del proscenio, simbolizarían, pues, las ciencias de los números en sus dos aspectos musical y astronómico. La tabla que comtempla Pitágoras, a partir de la cual toma anotaciones, presenta esquemas de armonías y concordancias musicales. El dedo de Platón expresa la orientación final: de la ciencia de los números a la música, de la música a la armonía cósmica y de ésta al orden divino de las Ideas.

Estaríamos, por tanto, ante una genial traslación del Urbinate a su propio tiempo y expresada pictóricamente según las cotas alcanzadas por este arte y él mismo está definiendo, que asume la tradición medieval de representar el Trivium (Gramática, Dialéctica y Retórica) y el Quadrivium (Aritmética, Geometría, Música y Astronomía), tal como aparece, por ejemplo, en el Hortus deliciarum, c. 1180, de Herrad von Landsberg, con las Artes Liberales en torno a la alegoría de la Filosofía que aparece en el centro y aquí tiene como base a Sócrates y Platón; era lo propio de los Studia Humanitatis desde la Baja Edad Media. A ello añade la tradición quattrocentesca de los Uomini Famosi de las bibliotecas o de algún Studiolo como el de Urbino. Conformado ese cualificado centro mediante las figuras de Platón y Aristóteles, auténtico umbilicus del templo ficiano de la sabiduría, en torno al cual gira todo.

Se alude en relación al cartón de la Ambrosiana, casi un estadio final de la obra, pero donde la figura comentada de Heráclito-Miguel Ángel no aparece ni tampoco la arquitectura, a una mayor libertad y articulación compositivas, respecto al dibujo inicial de Siena, pero que los efectos de claroscuro que se acentúan en lo conservado del cartón milanés, con una adhesión a modelos leonardescos no aparecen en la misma medida en el fresco definitivo, y esto casi como una crítica.

En el fresco, la arquitectura, el grandioso templo ficiniano comentado, como continente es fundamental, y ha de integrarse y adecuarse al resto de la composición, de tal modo que, en efecto, es preciso atenuar los efectos de luz y sombra, y esto se hace de forma voluntaria por el pintor; lo es respecto a figuras y grupos que, de manera aún más clara y diáfana que en el cartón, se dispononen de modo preciso y según estudiadas proporciones, así como movimientos, gestos y ademanes, regidos y subordinados a la composición y perspectiva generales, de tal forma que, sin convulsiones,

34 Tal como ha propuesto Claudio STRINATI, op. cit., p. 30. 
armónicamente y eludiendo todo tipo de efectismos, este cualificadísimo continente se distribuye, holgada y ritmadamente, en el geometrizado espacio ${ }^{35}$.

Aún resulta más sutil e infinitamente más refinado lo realizado a la inversa; esto es, adecuar el continente arquitectónico sin que pierda un ápice de su grandiosidad, al contenido, es decir, a la asamblea de eruditos y sabios personajes; y esto tomando como referente y punto de partida -mi convencimiento es total en este punto- la Flagelación de Urbino de Piero della Francesca ${ }^{36}$, que Rafael debió conocer desde siempre, que tenía fijada en su retina y memoria y que había estudiado atentamente, sobre todo la conformación del excepcional Pretorio y el planteamiento y dosificación lumínicos para definir sus planos de profundidad.

El continente arquitectónico de la Escuela de Atenas, muestra un sapientísimo uso, dosificación y control de la luz en los diversos planos y situaciones en profundidad, en anchura y, sobre todo, en altura. De este modo, se logra que el edificio, su envergadura y la plasticidad de sus formas, no minusvaloren el contenido, entendido como las figuras que "habitan", se mueven, dialogan y deambulan en peripatética discusión en el amplio espacio, y que lo hagan "cómodamente" y "con toda libertad".

Ya quedó insinuado al reseñar las hornacinas escorzadas de la profunda nave; volviendo sobre la cuestión, mesura y mensura lumínicas resultan magistrales en la secuencia hacia el fondo y en altura: primer medio cañón y su casetonado ${ }^{37} /$ espacio bajo la cúpula/ segundo medio cañón/ espacio abierto/ arco final también abierto, y a base más que de planos, de auténticos ámbitos o espacios lumínicos ${ }^{38}$.

Asimismo, Rafael para compensar la espacialidad planteada hacia el fondo del fresco, amplifica el proscenio lateralmente y, cortando la solería en primerísimo plano, consigue también proyectarlo hacia el espacio real de la Estancia, lo cual capta aún más la atención del espectador al que "invita" a entrar en el espacio pictórico; de nuevo el recuerdo de la tabla pierfrancescana, amplificado y reinterpretado, debió ser fundamental.

\section{El Parnaso}

La composición se despliega en torno a una amplia e importante ventana $(305 \mathrm{~cm}$. en su base que está casi a ras del suelo) que exteriormente se abre sobre el bramantesco patio del Belvedere. Es la consecuencia de Apolo y Marsias en conjunción con la Poesía, como excelsa manifestación de il Bello.

${ }^{35}$ Espacio medido y geometrizado, es claro, pero también que es un medio y no un fin en sí mismo, con una proporcionalidad perfectamente pautada.

36 Vid. los excelsos, en mi opinión, comentarios de PAOLUCCI, Antonio: Piero della Francesca. Catalogo completo dei dipinti. Florencia, Cantini, 1990, pp. 13-14 y Cat. 12, pp. 110-113; remitimos a [Addenda, Piero] al final de estas líneas sobre la Signatura.

37 Octogonales de dos tamaños, conformando una tupida red; magnífico ejemplo para Giulio Romano que, en el Palazzo Te de Mantua, desarrollará el tema y no ya en pintura, sino en genuinos casetones de todo tipo, forma y mediante las más diversas combinaciones.

${ }^{38}$ Notorio en lo que resulta visible del suelo entre las figuras protagonistas de Platón y Aristóteles. 


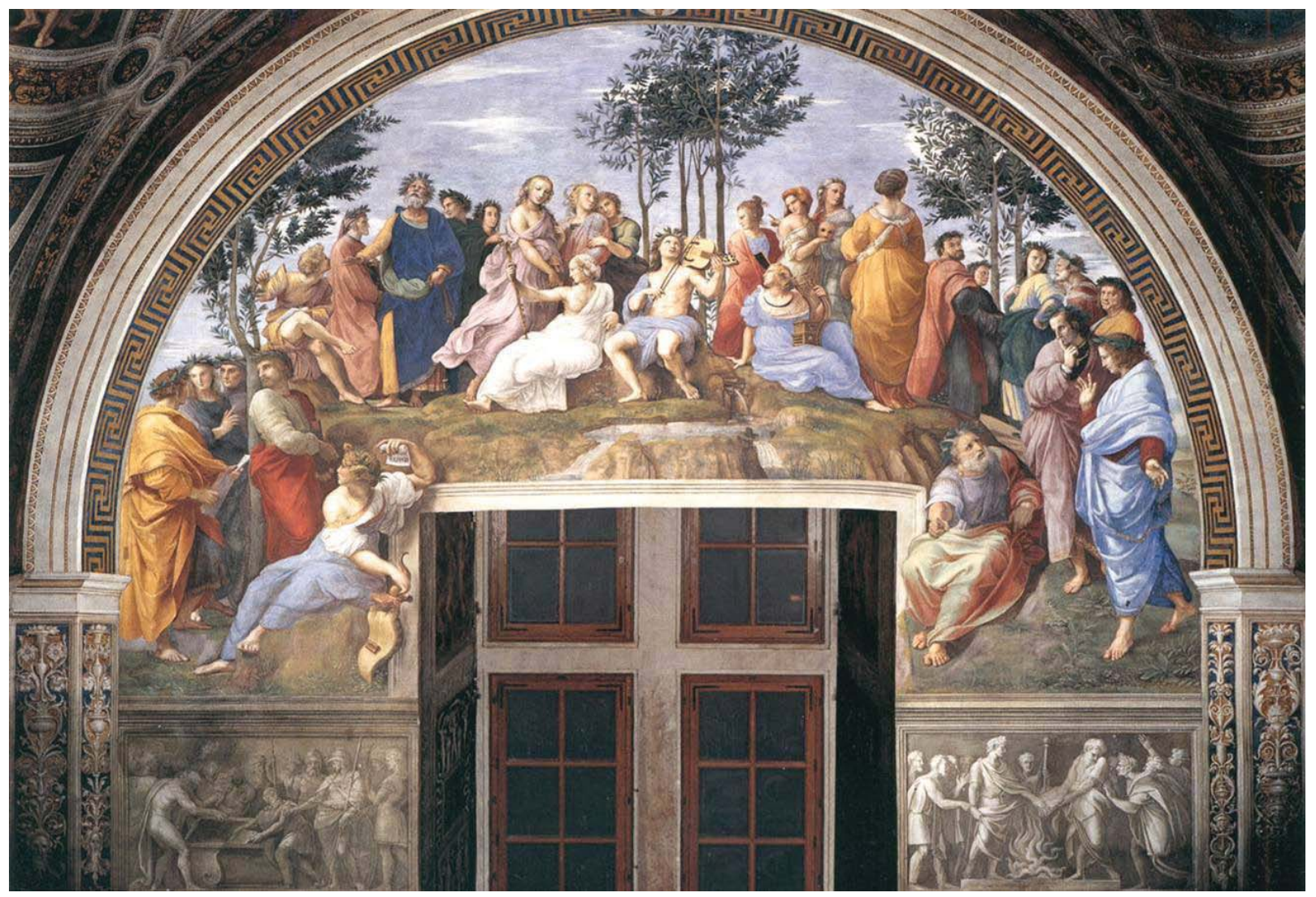

Fig. 7. Estancia de la Signatura. Parnaso y sus complementos.

En lo alto del mítico monte, junto a la fuente Castalia, Apolo toca una lira da braccio flanqueado por Calíope y Erato, que presiden el grupo de las restantes musas: Talía, Clío y Euterpe a la izquierda tras Calíope; Polimnia, Melpómene, Terpsícore y Urania, a la derecha detrás de Erato.

Una propuesta de identificación de los dieciocho poetas dispuestos en torno al dios, pudiera ser la siguiente: abajo a la izquierda: Alceo, Corinna, Petrarca, Anacreonte y Safo que sostiene un rollo de pergamino con su propio nombre; más arriba, Enio escucha absorto el canto de Homero, mientras Dante, más atrás visible entre los dos, mira a Virgilio que se vuelve hacia él, con Estacio o Statius a su lado; sólo un amago de subida se plantea por este lado. A la derecha, ahora sí, suavemente pero de manera clara, descienden de lo alto Tebaldeo, Boccaccio, Tíbulo, Ariosto, Propercio, Ovidio y Sannazaro. Abajo, en primer plano, como pendant de Safo, se sienta Horacio, que algunos piensan que es Píndaro. Ésta y otras identificaciones de los personajes es aún discutida, muy discutible siempre, problemática e hipotética. Parece haber quedado claro que para llegar a resutados satisfactorios, en todo caso, habría que hallar correspondencias concretas entre las nueve musas, los nueve poetas antiguos y los nueve modernos, además de agrupaciones según los géneros poéticos; por otra parte, los poetas antiguos del Parnaso tienen probablemente rasgos de humanistas contemporáneos de Rafael.

El proyecto original, al que corresponde el grabado de Marcantonio Raimondi, descrito por Vasari en lugar del fresco, preveía el grupo de Apolo, que aquí pulsa 


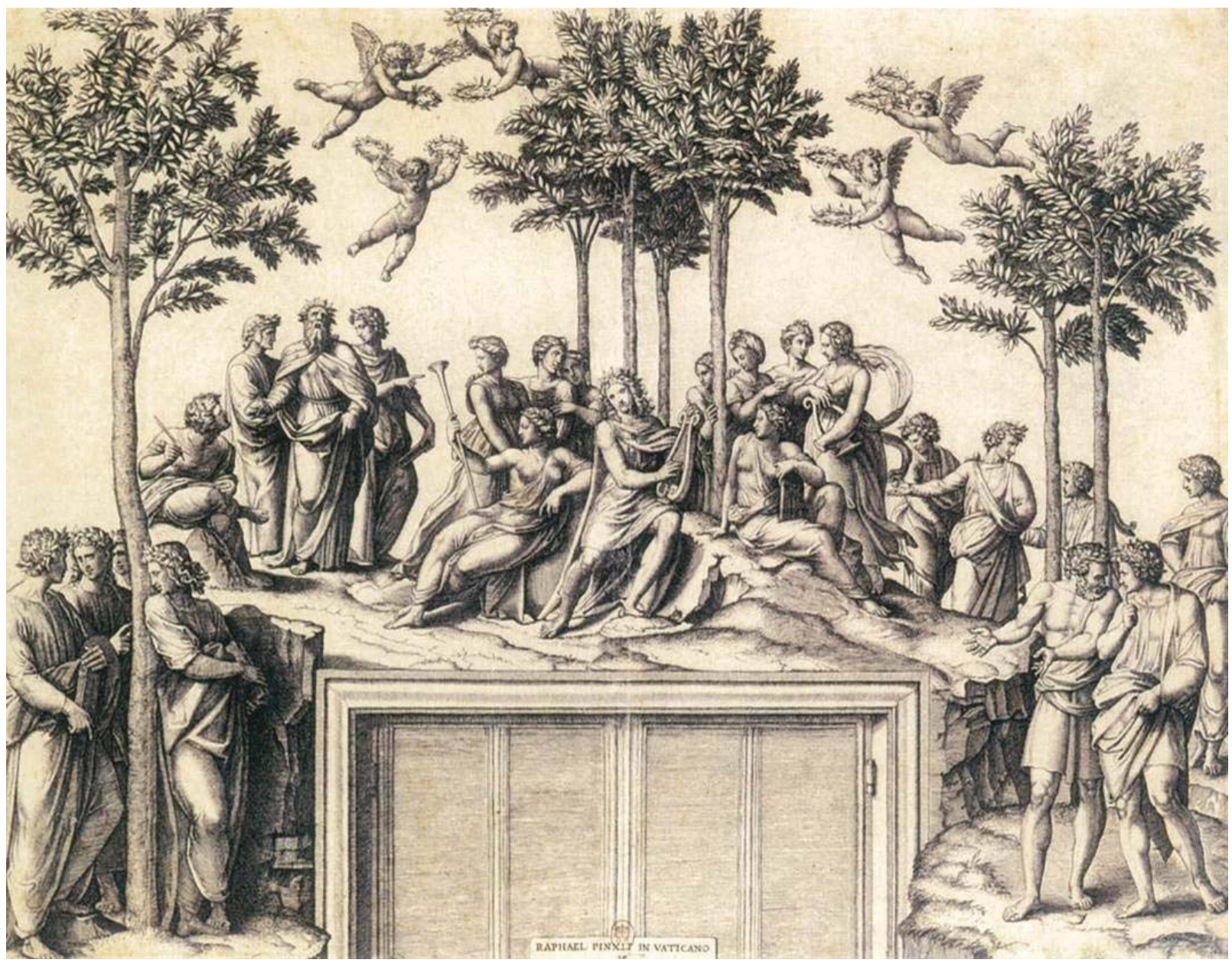

Fig. 8. Marcantonio Raimondi. Parnaso de Rafael; primera idea del Urbinate, c. 1510.

una lira, y las Musas en "una selva muy sombría de laureles", en lo alto de una colina y un grupo de putti en vuelo, con las coronas destinadas a los poetas. En un dibujo posterior del taller, ya se indica claramente el movimiento ascendente y descendente que liga a las figuras en relaciones rítmicas.

Los instrumentos pseudoantiguos del grabado, son sustituidos en el fresco: Calíope, Erato y Safo sostienen instrumentos puntualmente tomados del denominado Sarcófago de las Musas del Museo de las Termas (Roma); en cambio, Apolo toca una moderna lira de arco, como realzando el valor extrahistórico de la mítica figura, dotada de nueve cuerdas en vez de las siete usuales, de acuerdo el número de las musas y poetas antiguos y modernos.

El interés de Rafael por el clasicismo, inicialmente marcado por un vivo pero genérico entusiasmo que le empujaba sobre todo a buscar efectos de monumentalidad, va haciéndose gradualmente más concreto y arqueológico, de acuerdo con las orientaciones de los humanistas del contexto romano. Acentuando los motivos arcaizantes y mediante paralelismos entre poetas clásicos y modernos, Rafael opta por una imagen viva y alusiva al proceso lingüístico propugnado por los mismos humanistas de dar riqueza y dignidad al vulgar, mediante deducciones de la lengua latina. 
El fresco ha sido juzgado a menudo más elocuente que poético, declamatorio en las actitudes de los personajes; de algún modo, algo de esto es cierto, al verse forzado ante el efecto de intenso contraluz de la propia ventana en torno a la cual se despliega la composición, que lleva a la conformación y formulación de figuras de imponente apariencia escultórica e incluso a extremar posturas y actitudes, lo cual redunda en una entonación retórica más acentuada; pero se trata de alta retórica que responde plenamente a las exigencias y, al tiempo es reflejo, del ambiente en que trabaja el artista.

El fresco incluye la inscripción ${ }^{39}$ :

IVLIVS. II. LIGVR. PONT. MAX. AN. CHRIS. MDXI. PONTIFICAT. SVI. VIII.

Perfecto y más que significativo complemento de este Parnaso, son dos grisa$1 l a s^{40}$ que representan, a la izquierda bajo Safo, Alejandro Magno hace colocar los libros homéricos en la tumba de Aquiles, clara exaltación del legado y referente griegos y, a la derecha, Augusto impide que los ejecutores testamentarios de Virgilio quemen la Eneida, contundente diferenciación y afirmación de la latinidad y, en este sentido, muy conveniente sería que fuera Horacio y no Píndaro el poeta que está sobre la escena. De este modo la Iliada y la Odisea, por una parte, pero también la Eneida, se proponen cada una como un auténtico numen e hitos culminantes de Belleza.

Son pinturas realizadas tras completarse la decoración de toda la Estancia, usualmente fechadas en 1514 y, seguramente como se afirma, realizadas por Perin del Vaga según diseños de Rafael, por más que han sido también ponderadas y consideradas dignas del Urbinate, y por él realizadas.

El Mons Vaticanus por tradición era considerado entonces una suerte de Parnaso en plena Roma y, por tanto, locus, desde luego amoenus, donde habitaban Apolo y las Musas; bajo esta consideración y teniendo en cuenta que la citada ventana que arranca prácticamente desde el suelo y en torno a la cual queda desplegada la composición rafaelesca, es el punto de vista único y primordial, sito fuera de la obra, desde donde tenía sentido el conjunto del Belvedere bramantesco, con sus tres niveles, sus rampas, escalinatas y demás líneas perspectívicas, guiando y haciendo confluir la visión en el hemiciclo final, en un despliegue de arquitectura y natura de trescientos metros; Julio II debió sentirse literalmente encantado de esta parte de sus programas artísticos, de claves imperialistas, con su propio Parnaso, expresión en sí del Bello, desde donde vedere ese otro bello de naturaleza construida. Aún más, si nos imaginamos al Pontífice en su gabinete o estudio, rodeado de las taraceas lígneas de Fra'Giovanni da Verona que, a su vez, resumía y culminaba el género tras los legados de los hermanos Canozzi da Lendinara y Baccio Pontelli.

39 1511, como quedó puntualizado, y octavo año del pontificado de Julio II, oriundo de Génova y, por tanto, ligur.

${ }^{40}$ Muy apaisadas, de $185 \mathrm{~cm}$. de base. 


\section{Las Virtudes}

Es usualmente denominado Luneto de las Virtudes, con toda probabilidad al estar planteado como un medio punto muy rebajado, por tener que acomodarse a las disponibilidades -una vez más- de la Estancia; en esta pared la presencia de un alto vano centrado permite disponer, en cambio, como superficies a pintar, de sus laterales. Es, al parecer, el último de los episodios parietales acometidos por Rafael; último asimismo en la narración vasariana.

Frente por frente a El Parnaso, este luneto ha de ser contemplado con una cierta obligatoriedad desde un punto de vista bajo, y a ello responde la disposición rafaelesca; sobre un gran zócalo que imita mármol, se sientan tres figuras femeninas que simbolizan, de izquierda a derecha según se mira el fresco, La Fortaleza con yelmo en la cabeza y sosteniendo una rama de roble, en alusión al apellido y linaje del Papa; La Prudencia, prácticamente en el centro, vestida de verde y blanco con una máscara de perfil masculino entre los cabellos, en la parte posterior de su cabeza y, al tiempo, comtempla un espejo que un putto le sostiene al efecto, dando a entender una vigilancia constante y hacia todas partes; y La Templanza que sujeta unas riendas, es decir, "templa" mediante éstas.

Se figuran, pues, tres de las Virtudes Cardinales, la cuarta, La Justicia, "domina" este grupo desde la bóveda; queda explícito de este modo su condición primordial y principal, ya que, según la doctrina de Platón recogida por San Agustín, la justicia es superior a las otras en jerarquía. Un total de cinco putti, mediante armoniosos movimientos y gestos, actúan como nexos entre las sobrias figuras femeninas, imprimiendo a la composición un ritmo suelto, agraciado y en un continuum sin estridencias. Tres de ellos personifican a Las Virtudes Teologales; el que toma frutos de la rama que porta la Fortaleza, simboliza La Caridad, en tanto que hacia el centro, el que sostiene una antorcha encendida, personifica La Esperanza y, en la derecha, el que significativamente señala hacia el cielo, es $\mathrm{LaFe}$.

Las formas amplias y de estructura monumental de las figuras femeninas, no sólo muestran atención e influjos de Miguel Ángel, sino que éstos ya han quedado integrados y dominados en la pintura y poética rafaelescas que, de modo coherente y con muy atinados resultados, los inserta en un ritmo compositivo, digamos "clásicamente pautado" y con certeras dosis de mesura y contención ${ }^{41}$, al tiempo que sus posturas

${ }^{41}$ Ya no recuerdo dónde ni cuándo, pero sí que he leído que la dulzura desplegada por Rafael, creo que en relación con sus Madonne florentinas que superaban la sensiblería peruginesca, debió aprenderlo e impregnarse desde niño, contemplando la Madonna que Luca della Robbia realizó para el tímpano de la iglesia de Santo Domingo en Urbino, hoy en el Museo Nazionale delle Marche; se trata de una exquisita terracota vidriada y policromada que, al modo de Luca, sin concesiones a ningún tipo de anecdotismos, sin renunciar nunca a una idea de "escultura mayor", manifiesta la belleza y la gracia que constantemente reitera Vasari respecto a Rafael, y aquí pudo aprender también el Urbinate ese distanciamiento que prodiga en sus obras. Estudios del natural, muchos sí, pero finalmente aplica esa certa idea interior, de la que él mismo habla, para lograr esas figuras quasi arquetípicas, esencia del "arte clásico" desde los días de Fidias, que, en ocasiones, incluso con ribetes críticos se aplica a Rafael, "como avaro en comunicar una emoción más honda, cerrado en su precioso limbo -yo diría Olimpo- en que es difícil alcanzarle", según comenta Michele Prisco en su introducción de la op. cit. de Pierluigi De Vecchi. 


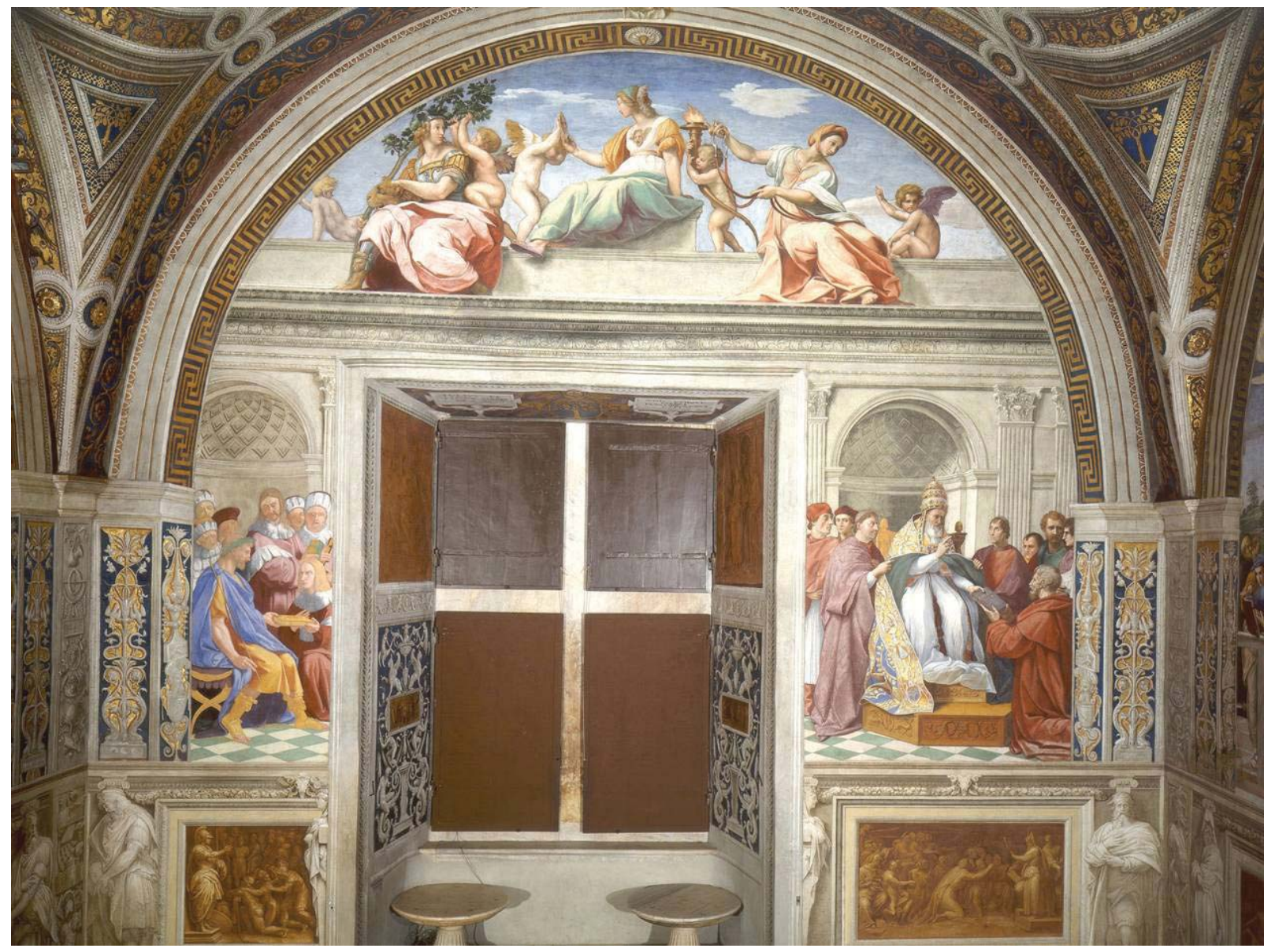

Fig. 9. Estancia de la Signatura. Luneto de las Virtudesy sus complementos.

más ágiles y movidas preludian, de alguna manera, soluciones de la siguiente Estancia de Heliodoro.

Aparece aquí, como en el Parnaso la inscripción:

\section{IVLIVS. II. LIGVR. PONT. MAX. AN. CHRIS. MDXI. PONTIFICAT. SVI. VIII.}

Complementando este luneto, bajo el mismo y a ambos lados del señalado vano, dos escenas ${ }^{42}$ que sí pueden ser interpretadas como la Jurisprudencia, lo cual no resulta lícito -y se hace a menudo- en cambio, como designación global de estas pinturas parietales en este nivel inferior que, como queda reseñado, preside la Justicia en la bóveda que está en relación con el Juicio de Salomón; es decir, en conjunto se trata del Bien como concepto y sus consecuencias o explicitaciones.

En efecto, se trata ahora de la representación de sendos hitos y referencias entonces, tanto del derecho civil como del derecho canónigo o canónico. A la izquierda, según se mira, y del lado de La Escuela de Atenas, subrayando su condición de acto solemne y celebrativo del derecho natural, Triboniano entrega las Pandectas a Jus-

42 Cada una de $220 \mathrm{~cm}$. de base. 
tiniano $^{43}$. Texto jurídico clave y de constante referencia que, desde el siglo VI y asumiendo todo el legado romano, actuaba aún como guía y fuente; algo parecido a lo que en el ámbito hispano sucedía con las Partidas de Alfonso X el Sabio, hasta bien entrada la Edad Moderna.

A la derecha y del lado de la Disputa, la celebración del derecho eclesiástico, Gregorio IX aprueba las Decretales; el pontifice en cuestión tiene aquí los rasgos de Julio II y a su izquierda es directamente asistido sosteniendo el pluvial, por el cardenal Giovanni de'Medici, futuro León X, tras el cual han sido identificados también los cardenales Francesco del Monte y Alejandro Farnesio, futuro papa Paulo III.

En cuanto a la ejecución de estos dos últimos frescos, poniendo en práctica ideas y diseños de Rafael, la crítica es casi unánime en considerarlos obras del taller; no obstante, al haber sufrido graves daños y restauraciones no del todo correctas, la lectura de los mismos ha sido difícil. En la actualidad, tras las oportunas correcciones y eliminación de repintes, presentan un aceptable aspecto.

\section{Colofón no conclusivo}

Literalmente unas pocas líneas y desde luego sin conclusión alguna por parte del que escribe, no sólo porque no ha sido el ánimo e intención de estas reflexiones y conjeturas, como así quedaron presentadas, sino para que sea, y esto sí es una razón de peso, el propio Rafael quien concluya.

En efecto, la conclusión de esta Estancia de la Signatura supone en la trayectoria del Urbinate un punto de no retorno. Culminado este completísimo ciclo y, aún sin acabar en 1511, ya estaba ideando y planteando otro con varios frentes, pero ante todo proyectando su segunda Estancia Vaticana, la Estancia de Heliodoro que, si programáticamente no es comparable a la Signatura, lo que durante el intervalo 1511-1514 realiza en la segunda Estancia, sería hasta impensable entre 1508/ 1509 y 1511.

Los problemas planteados y resueltos denotan el vertiginoso ritmo de progresión y avance, con nuevos retos y soluciones. Basta el somero resumen siguiente, referido a los frescos parietales de la nueva Estancia.

- Grupos compactados y contrapuestos en dinamismo y quietud contemplativa, que dejan como centro y eje de la composición, de manera notoria, inquietantes vacíos; fuga convulsa y rapidísima de la perspectiva, con secuencia de elementos arquitectónicos dramáticamente escandidos por la luz (Expulsión de Heliodoro).

- Densificación y opacidad colorística, de tal modo que llegan a ser elementos expresivos claves de la composición (Misa de Bolsena).

- Contrastes lumínicos violentísimos que se erigen en protagonistas de la obra (Liberación de San Pedro).

- Planteamiento acusadamente asimétrico de la composición (Atila y León Magno, concluido ya bajo León X).

${ }^{43}$ El emperador bizantino Justiniano se sienta en un Falsistorio, como Pilatos-Juan VIII Paleólogo en el Pretorio de la Flagelación de Urbino que Piero della Francesca pintara unos cincuenta años antes; un dato más sobre lo ya reseñado.. 
Según todo lo "reflexionado y conjeturado", resulta lícito valorar la Signatura como la conclusión de unos ideales de armonía, plenitud, orden y belleza ya consumados, donde Rafael alcanza altísimas cotas; todo un manifiesto pictórico y de cultura artística, presididos por una trinidad indisoluble: perspectiva-proporción-simetría.

\section{[Addenda, Piero]}

Verdaderamente una tablita sin marco, sólo 59 X $81,5 \mathrm{~cm}$. de inconmensurable pintura, hoy parte de los fondos de la Galleria Nazionale delle Marche, instalada en el Palacio Ducal de Urbino, donde ingresó en 1916. Hacia mediados del Settecento, su presencia está documentada en la sacristía de la catedral de Urbino y está firmada: OPVS PETRI DE BVRGO SCI. [Sancti] SEPVLCRI. Ningún otro dato o referencia.

Es preciso a todas luces -nunca mejor dicho- considerar la obra como perteneciente a la fase de plena madurez del maestro de Borgo San Sepolcro, hoy Sansepolcro, con toda probabilidad de 1460 o poco después y quizá encargo de la propia corte de los Montefeltro.

Al margen de su significado, sería, pues, la pintura que inauguraría ese período de plenitud de Piero en Urbino que, para el maestro, debió significar una suerte de segunda juventud como la vivida en la Florencia de treinta años antes, en un contexto cortesano que rápidamente estaba afirmándose como el centro de cultura internacional más refinado de Italia. Aquí Piero reencontró seguramente el placer de la discusión, el gusto por la experimentación y la confrontación, todo un fervor intelectual que deviene del convencimiento de saberse, c. 1460-1474, el decisivo protagonista, sotto l'amichevole protezione di Federico da Montefeltro.

La Flagelación de Urbino resulta un fascinante testimonio, no explicable sin considerar el encuentro con Battista Alberti (en Rimini, 1451; reencuentro si, c. 1439, existió uno previo en Florencia), Leon fiorentino, en una dimensión intelectual obviamente.

Alberti, sus pautas y teorías fueron factores, sin duda alguna, decisivos que impulsaron a Piero a considerar la arquitectura y la perspectiva datos esenciales de la escenografía pictórica; en La Flagelación de Urbino, realmente una arquitectura "protagonista", como afirmaba Eugenio Battisti, pero asimismo es un decisivo ejemplo del colorare que Piero no ha querido tratar en su De prospectiva pingendi, ¿c. 14601470?, que quedó manuscrito, ya que al pintor de la luz, la imprenta le negó la suya.

Esto resulta palmario en el Pretorio de Pilatos de la Flagelación; en efecto se trata de un punto álgido, acaso el más significativo, de síntesis entre senso della profondità atmosferica e profondità calcolata della prospettiva, según comentaba Kenneth Clark. Queda así plasmado un espacio verdaderamente poético donde las figuras "en silencio casi ritual" actúan; espacio milagrosamente pautado por la luz que define y acaricia los planos de profundidad, expresando una perfecta simbiosis entre percepción y concepción. 


\section{Vasari, las Vite}

Por más que estas reflexiones y conjeturas hayan de ser razonablemente sucintas, no es posible, desde la óptica de la Historia del Arte, prescindir de una referencia por breve que sea, en este 2011, a Giorgio Vasari; además es preciso abundar un tanto en datos y puntualizaciones del aretino sobre el Urbinate que complementen, aclaren o perfilen lo dicho.

Obviamente la razón de incidir en Giorgio Vasari, al socaire del quinto centenario de su nacimiento en Arezzo, se debe a su aportación teórica, sin paliativos y sin duda alguna, una contribución decisiva a la cultura artística occidental. Me refiero, claro está y al margen de otros escritos necesariamente "menores" 44 , a esos auténticos monumenta que son sus Vite, publicadas en Florencia bajo auspicios mediceos (duque Cosme I de'Medici) en 1550 (edición torrentina ${ }^{45}$ o torrentiniana) y en 1568 (edición giuntina ${ }^{46}$ o giuntiniana), que no son meramente ampliación una de otra, sino dos obras en dos momentos, en dos contextos y según intención y alcance diversos, y, en este sentido, conviene por no decir que es fundamental hacer la diferenciación.

Consciente el aretino de la trascendencia de su obra escrita, en su segundo lega$\mathrm{do}^{47}$ de 1568 , que concluye con su autobiografía, incluida evidentemente en base a su condición de pintor y arquitecto, "se permite" jugando con los términos penna e pennello, o sea pluma y pincel ${ }^{48}$, ponderar su labor con el segundo, es decir sus trabajos y trayectoria como pintor, pero convencido de modo pleno que su contribución escrita constituye el mejor aval y la razón para su fama e inmortalidad, aspiraciones legitimadas por el contexto de hondo y consolidado sentido humanista, al tiempo que hace manifiesta la convicción de culminar una labor callada de toma de datos y acumulación de noticias, al menos desde 1540 pero seguramente desde bastante antes, y con el prestigioso precedente -"fogonazo" previo, "contestado" por Condivi

${ }^{44}$ Así las Ricordanze y el Zibaldone, que quedaron manuscritos y han sido publicados sólo en el siglo XX, del mismo modo que sus Cartas, por DEL VITA y FREY.

45 De hecho, y no es frecuente que se aluda a ello, Lorenzo Torrentino o Laurentius Torretinus, de cuyo apellido deriva el nombre de esta edición vasariana, era realmente Laurens van den Bleeck (14991563), oriundo del norte de Brabante y establecido en Florencia al servicio -impresor ducal- de Cosme I de'Medici (vid. MOREDI, Domenico: Annali della tipografia fiorentina di Lorenzo Torrentino; edizione seconda, corretta e aumentata, Florencia, 1819 (1 $1^{\text {a }}$ ed., 1811); reed., Florencia, 1989).

${ }^{46}$ I Giunti, entonces impresores ducales; se trataba de los herederos de Filippo il Vecchio, activo entre 1497 y 1517 que, en la historia de la tipografía italiana, usualmente es puesto en paralelo con el veneciano Aldo Manuzio; editorial aún hoy activa, desde su mítica sede florentina de La Loggia.

${ }^{47}$ Ahora es: "Delle vite de'piv eccellenti Pittori Scvltori et Architettori, in Fiorenza, Apresso i Giunti, 1568"; 3 vols.; "Prima, e Seconda Parte" [BH FG 3513 y BH FLL 35465]; "Primo Volume della Terza Parte" [BH FG 3514 y BH FLL 35467] y "Secondo, et vltimo Volume della Terza Parte" [BH FG 3515 y BH FLL 35466], citados por los ejemplares de la editio princeps, considerada bastante rara, de los fondos de la Biblioteca Histórica Marqués de Valdecilla. Universidad Complutense de Madrid; BH, por operatividad y brevedad (vid. SUÁREZ QUEVEDO, Diego: Arquitectura y ciudad. Memoria e imprenta, catálogo de la exposición de igual título, marzo-julio de 2009. Madrid, Universidad Complutense. Servicio de Publicaciones, 2009; respecto a Vasari, pp. 54-58 y 102-105).

48 Vid. DÍAZ MORENO, Félix: "Vasari y la literatura artística", "Apuntes de Arte y Socierdad" (n ${ }^{\circ}$ 3, junio 2011, pp. VIII-XII; coord. M ${ }^{\text {a }}$. Victoria Chico Picaza), CDL (Boletín del Colegio Oficial de Doctores y Licenciados en Filosofía y Letras y Ciencias de Madrid), nº 225 (junio, 2011), pp. 20-24. 


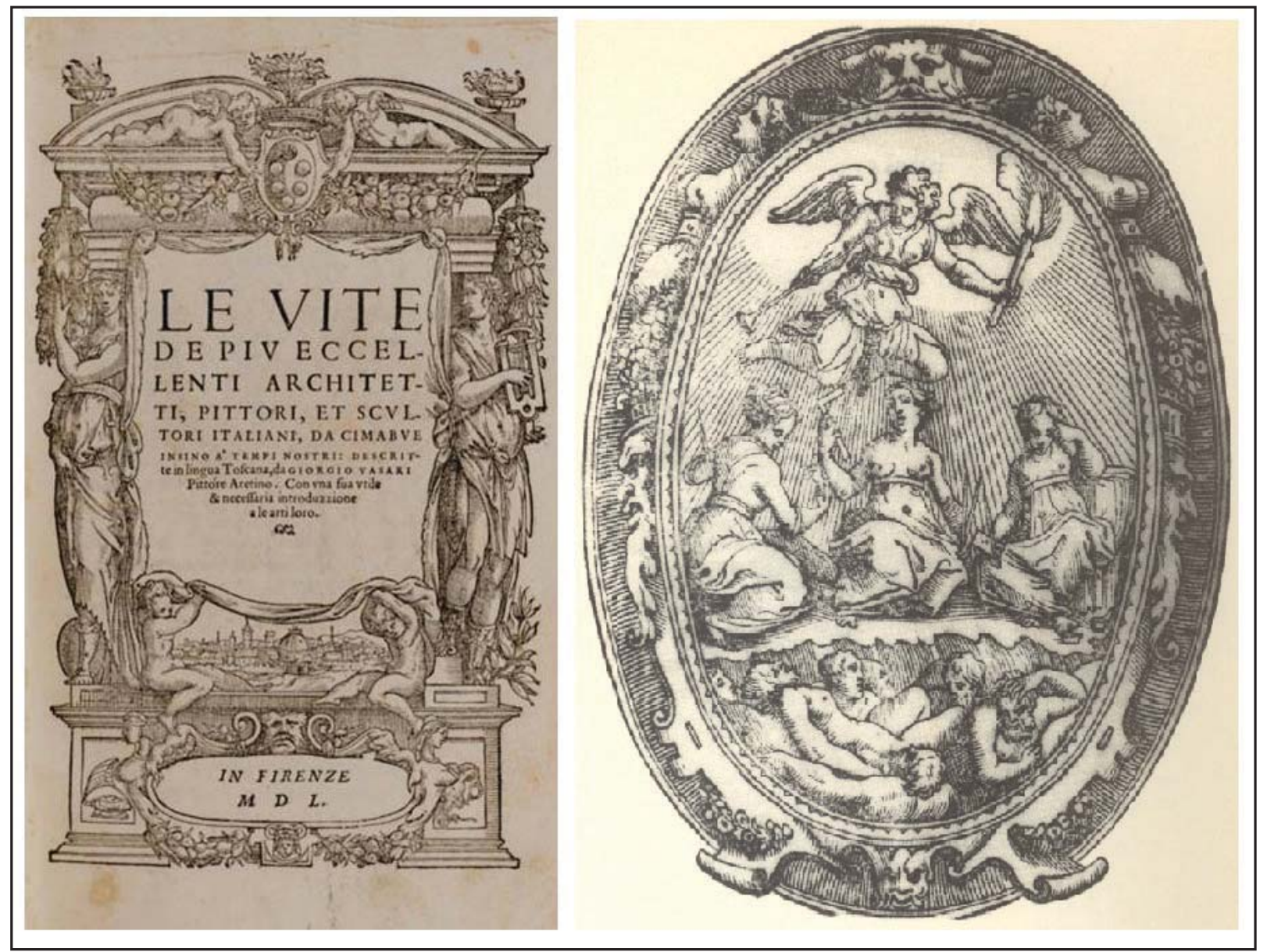

Fig. 10. Vasari, Vite, 1550, frontispicio y xilografía final (alegoría de los artistas muertos, la Fama y las tres Artes Mayores).

respecto a Buonarroti en 1553 al que, a su vez, "replica" ahora- de la edición de 1550, culminada en Miguel Ángel ${ }^{49}$.

No existe mejor refrendo de lo dicho que el propio retrato en la xilografía inserta en el primero de los volúmenes de los tres correspondientes a las Vite, 1568, tras el frontispicio de la Portada y la Alegoría de La Fama, las Tres Artes Mayores y los Artistas; en los tres casos con el rico y honorífico enmarque, muy diferente al relativamente sencillo asignado a cada biografiado ${ }^{50}$.

49 En relación con la Vita de Miguel Ángel, 1553, de Ascanio Condivi como a la previa vasariana, Vite, 1550 , en lo que a Buonarroti se refiere, son de tener en cuenta, las versiones sugeridas y los datos facilitados, y "hasta impuestos" a ambos, por el gran artista de Caprese.

50 Vid. SUÁREZ QUEVEDO, Diego: "El viaje y la literatura artística. Un recorrido con Vasari”, en El tema del viaje: un recorrido por la lengua y la literatura italianas (coordinadoras: $\mathrm{M}^{\mathrm{a}}$. Josefa Calvo Montoro y Flavia Cartoni; colaboradores: Paolo Gimmelli y Marilena Da Rold). Cuenca, Edición de la Universidad de Castilla-La Mancha, 2010, pp. 859-888 (Actas del XII Congrso Internacional de la SEI [Sociedad Española de Italianistas], Almagro, noviembre de 2008, presentado con el título: Il Viaggio e la letteratura artistica. Un percorso col Vasari). 
Ya Schlosser calificaba a Vasari, con sus luces y sombras, como el auténtico patriarca y padre de la "iglesia" de la nueva historia del arte, con una abierta objetividad a la que tendía y que a menudo alcanzó frente a las manifestaciones artísticas más dispares ${ }^{51}$.

Las Vite, dentro de la literatura artística, inauguraron un género biográfico $0^{52}$ que fue detonante para otros ámbitos, eso sí, con adaptación a cada contexto específico; baste recordar a Karel van Mander y su Schilderboek sobre los pintores flamencos, publicado en 1604. Por lo que al caso hispano se refiere, Lázaro Díaz del Valle en su manuscrito, fechable entre 1656 y 1662, hace lo propio siendo, cuando menos, un preámbulo del Parnaso español de Antonio Palomino, publicado ya en 1724.

En la literatura artística italiana marcó una pauta a seguir, como es el caso de Giovanni Baglione $e^{53}$ que, sin solución de continuidad, propone para el intervalo 1572-1642, una suerte de continuidad de las biografías vasarianas.

Las Vite vasarianas, pues, son textos claves de la cultura artística occidental, en sí mismos con un más que notable valor histórico abarcando tres siglos, desde Cimabue al propio Vasari; no se trata, no obstante, de meras biografías de artistas y repertorios de obras más o menos analizadas y valoradas, sino que formula y define, sobre todo en sus importantes proemios, todo un discurso que auna teoría, estética y normatividad clasicista, fundamentado en un irrenunciable primato del disegno, al tiempo que va perfilando toda una nueva terminología artística y formulando un léxico ${ }^{54}$ específico; asimismo va planteando una crítica fundamentada en la mayoría de los casos, mediante una valoración, en general objetiva, de las diversas aportaciones en sus respectivos contextos.

Una suerte de ética profesional y de compromiso con el arte es también puesta en valor y, de algún modo, ha de ser reconocida por el comitente -personal o institucional; el príncipe, laico o religioso, en el sentido genérico del término- como obligación del estatus de la propia posición y, de este modo, contribuir a la fama que ha sido noblemente lograda.

También, Vasari, es tendencioso, él mismo en ocasiones y además el entorno mediceo que patrocina e instrumentaliza la publicación; se pondera ante todo lo toscano, lo florentino y los artistas que han trabajado para la Casa Medici; más, en general, lo basado en el dibujo que en el color y, por otro lado, casi es repudiado lo considerado antimiguelangelesco, siendo acaso el más significativo ejemplo la total proscripción de Pirro Ligorio, y tampoco son "dignos" de una biografía Serlio o Vignola ${ }^{55}$, obviamente en las Vite, 1568.

${ }^{51}$ SCHLOSSER, Julius: Kunstliteratur. Viena, 1924; ed. española: La literatura artística. Manual de fuentes de la historia moderna del arte. Presentación y adiciones por Antonio Bonet Correa. Madrid, Cátedra, 1976, p. 290.

52 Como precedente habría que contabilizar al historiador florentino Filippo Villani (1325-1407) y su Liber de origine civitatis et eiusdem famosis civibus, c. 1380.

${ }^{53}$ Le vite... Roma, 1642 [editio princeps: BH FLL 35471]

${ }^{54} \mathrm{Al}$ respecto, vid. MONTIJANO GARCÍA, Juan María: Giorgio Vasari y la formulación de un vocabulario artístico. Málaga, Universidad de Málaga/ Real Academia de Bellas Artes de San Telmo, 2002.

${ }_{55}$ Frente a los casos de Vignola y Ligorio, Palladio, como académico florentino auspiciado por el propio Vasari, sí encuentra acomodo y es loado en las Vite, 1568 (vid. SUÁREZ QUEVEDO, Diego: "Centenarios de Vignola (2007) y Palladio (2008). Apuntes, acentos", Anales de Historia del Arte, $\mathrm{n}^{\circ}$ 18 (2008), pp. 271-316). 
Mediante una prosa cuidada y pulcra, con una efectividad narrativa y descriptiva notorias, las Vite están escritas en vulgar, lo cual, al margen del desconocimiento o no dominio del latín, es, en este caso y desde mediados del Cinquecento, una clara opción con ribetes nacionalistas en pro de la lengua de Dante. Entre los aspectos más valorados hoy día por la crítica, figuran las continuas anécdotas plasmadas, no siempre ciertas pero sí con un trasfondo e intencionalidad avalado por el contexto.

Las Vite quedan planteadas, en el amplio arco cronólogico que abarca, de un modo progresivo y positivamente evolutivo hasta la propia época del autor Terza Età, Terza Maniera o auténtica Maniera Moderna, que significativamente se inicia con la biografía de Leonardo; el Quattrocento, Seconda Età o Maniera supone definir y afirmar una serie de presupuestos que posibilitan el paso siguiente, desde los primeros atisbos de coherencia, desde su perspectiva, en que se abandona la denominada Maniera Greca, entendida como gótico-bizantina, con I Primi Lumi de Giovanni Cimabue y Giotto. De este modo, se evoluciona desde las tenebre del arte hasta la luz, en claves clasicistas o de rinascere all'antico.

Las Vite, 1550 se estructuran, desde un proemio general, mediante una amplia introducción con apartados dedicados a la arquitectura, la escultura y la pintura y proemios específicos a cada una de las tres partes en se agrupan las biografías hasta 1547, desde Cenni di Peppi más conocido como Giovanni Cimabue (c. 1240c. 1302) hasta Miguel Ángel (1475-1564), de artistas ya difuntos salvo el último, cenit, culmen y héroe a ultranza de la obra, referente ideal y auténtico numen vasariano sin paliativos, ya mitificado e inmortalizado en vida ${ }^{56}$.

Es únanime la superior valoración y consideración de estas Vite, 1550, literariamente hablando, con sus eslabones mejor imbricados en una lograda continuidad narrativa y en crescendo coherente y válido; una mayor diafanidad y frescura en la exposición de datos y juicios, mediante una prosa severa que, de algún modo quedarán atenuados en las Vite, 1568.

Unas breves pero sugestivas conclusiones dirigidas a gli (sic) artefici et a'lettori constituyen el remate, donde Vasari anuncia su intención de complementar esta obra con nuevas biografías, promettendovi pur da me fra non molto tempo una aggiunta di molte cose appartenenti a questo volume, con le vite di que'che vivono; finalmente una xilografía muy elocuente con un refinado marco oval con mascarones, un par hermas y molduras o placas recortadas que, a intervalos, se enroscan, y guirnaldas florales; en un nivel superior una figura femenina alada con trompeta y antorcha como alegoría de la Fama, desde cuyo entorno lumínico parten una serie de rayos que caen sobre otras tres figuras femeninas, situadas en una zona intermedia, que representan a las tres artes mayores, en el centro la Arquitectura, a su

56 De facto esto era ya una realidad, y no sólo artística y literariamente hablando; no conviene olvidar que en el Arco de los Florentinos -de la pujante comunidad comercial-financiera florentinalevantado en Amberes en 1549 con motivo de la Entrada en la ciudad del entonces príncipe y luego rey Felipe II en su Felicísimo viaje europeo, según nos relata el cronista Calvete de Estrella, entre los próceres culturales de la ciudad del Arno, fue colocada una escultura efímera del divino Miguel Ángel, aún vivo y activo en Roma, junto a la de Giotto (c. 1267-1337) y a las de los tres grandes literatos toscanos del Dolce Stil Nuovo: Dante Alighieri (1265-1321), Francesco Petrarca (1304-1374) [también, como Vasari, aretino] y Giovanni Boccaccio (1313-1375). 


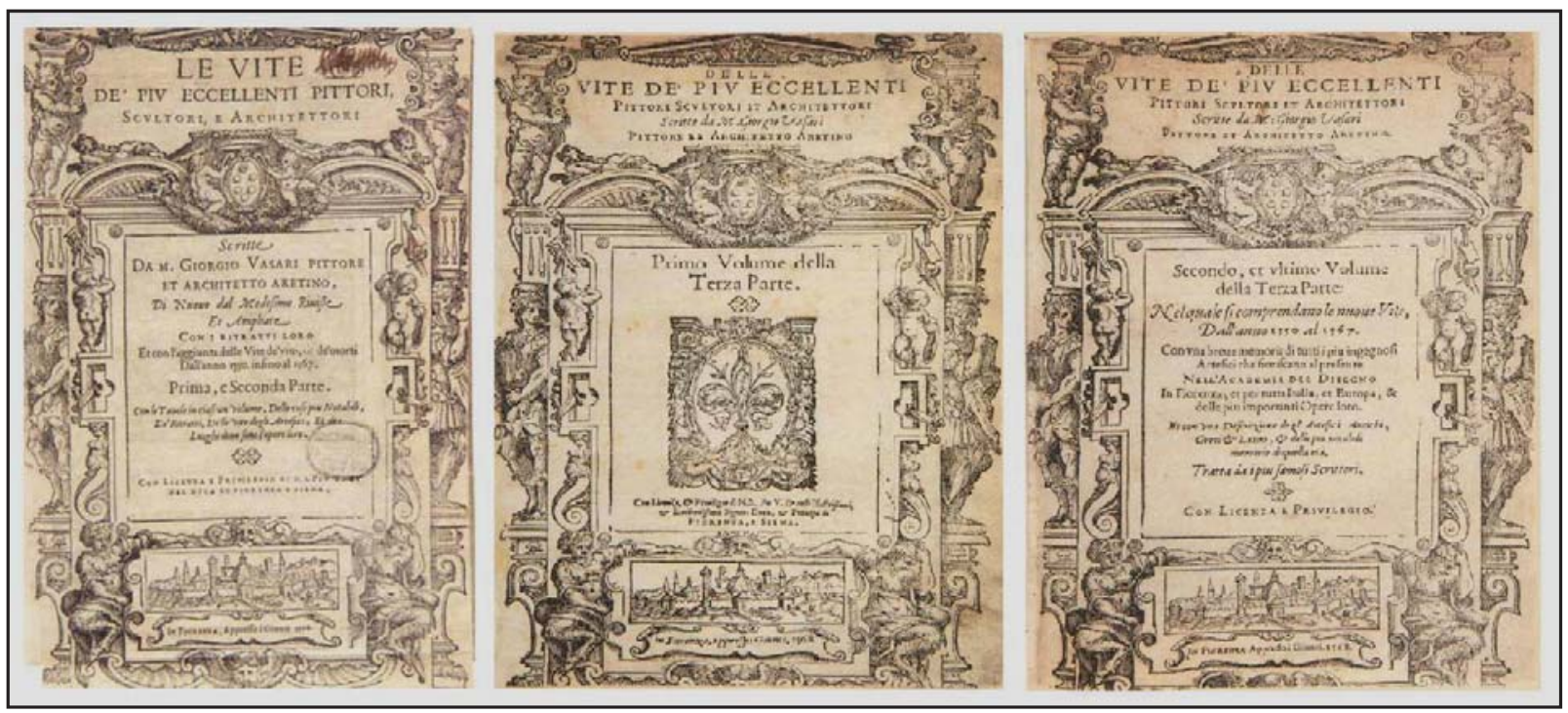

Fig. 11. Vasari, Vite, 1568, frontispicios de sus tres volúmenes [BH FG 3513 y BH FLL 35465], [BH FG 3514 y BH FLL 35467] y [BH FG 3515 y BH FLL 35466].

izquierda la Escultura y a su derecha la Pintura; bajo éstas y con un elemento de separación, los artistas muertos.

El influjo e incluso magisterio sobre Vasari de conspicuos humanistas, ante todo Paolo Giovio, fallecido en Florencia en 1552, o Cosimo Bartoli que, aunque sobrevive a las segundas Vite -vivirá hasta 1572-, gravitaron notablemente sobre esta edición torrentiniana, evidente en la muy cualificada consideración de Alberti, aquí altamente positiva, que no será el caso de la edición giuntiniana, en que toma "todas las riendas" el propio aretino.

Por su parte, las Vite, 1568, constituyen la culminación, o cuando menos una de las culminaciones, de la trayectoria artística y profesional de un Giorgio Vasari que, desde 1555 , es, en la refinada y exquisita corte medicea que es asimismo muy exigente, el auténtico capostite ufficiale que debe atender a las plurales necesidades cortesanas, lo cual significa una gran dedicación y responsabilidad.

Por otra parte, en 1562 es fundada oficialmente la Accademia Fiorentina del Disegno, bajo auspicios del duque Cosme I y reasumiendo anteriores corporaciones artísticas como la pictórica de San Lucas, que luego será la Accademia di Belle Arti. Giorgio Vasari fue factotum hasta su fallecimiento de esta institución cinquecentes$c a$, con la colaboración, ante todo, del escultor y arquitecto Bartolomeo Ammannati (1511-1592) y del filólogo e historiador Vincezio Borghini, estrecho colaborador de Vasari en la organización de la citada Accademia y de la redacción de las Vite, 1568.

En 1563 llega a Florencia la emblemática aprobación de Miguel Ángel a la institución académica $y$, al año siguiente, tras su fallecimiento en Roma, los restos mortales del eximio artista mediante hábil maniobra político-diplomática personal del Duque $^{57}$; de inmediato, y bajo dirección y supervisión de Vasari desde la Accademia,

57 Aquí conviene recordar que Pío IV, era entoces el papa reinate hasta su fallecimiento el 9 de diciembre de 1565; Giovanni Angelo de'Medici, de una rama menor milanesa de los Medici florentinos. 
exequias y conmemoraciones fúnebres al efecto, que culminarán con el diseño vasariano del monumento funerario de Buonarroti en Santa Croce de Florencia, que se realizará en los años sucesivos. Y ya ir ultimando la composición de las "nuevas" Vite, meta que se había propuesto y había anunciado en 1550.

Partiendo y reutilizando el texto de las anteriores Vite, adaptado, corregido, retocado y del que se suprimen muchos párrafos -prácticamente todos los epitafios- de modo que hay datos de la edición torrentiniana que no pasan a la giuntiniana, se van añadiendo e intercalando una enorme cantidad de complementos de todo tipo y nuevas biografías, ahora sí, también de artistas vivos, al tiempo que se integran referencias de ilustres artífices flamencos, entre otros añadidos, incluida la biografía del propio autor, que ahora remata la obra. Quedan así conformados tres volúmenes plenos de una información ingente -mérito indiscutible de estas nuevas Vite- dedicado el primero al Trecento y Quattrocento, o sea primera y segunda partes de la obra, al que siguen un Primo Volume della Terza Parte y un Secondo, et vltimo Volume della Terza Parte, todos publicados IN FIORENZA, Appresso i Giunti en 1568.

De este modo, la sensación de acumulación es notoria y el preciso hilo conductor que culminaba en Miguel Ángel de las anteriores, se ha perdido -a mi juicio, también se buscaba su disolución, como luego se dirá- y la notable frescura narrativa de las Vite, 1550, queda literalmente sepultada en un mare magnum de datos, en ocasiones incluso repetidos, como en el caso de la biografía de Baldassare Peruzzi.

Se mantiene básicamente la estructuración mediante proemios y biografías, ahora aumentadas, con l'aggiunta delle Vite de'viui, \& de'morti, dall'anno 1550 infino al 1567, pero además con i ritratti loro; es decir, cada biografía se inicia con la correspondiente xilografía-retrato, al parecer no todos fidedignos y en algunos casos aparece sólo el enmarque; éste es relativamente sencillo, con alegorías de las tres artes mayores en la estructura cuadrangular que hace de continente de un marco oval donde se sitúa el busto correspondiente, en el centro, y en la parte inferior, cartela con el nombre del biografiado y la especificación de su -o sus- disciplina artística.

Como contraportada del volumen primero de estas Vite, 1568, la alegoría con la Fama, las tres Artes Mayores y en la zona inferior los artistas que ahora parecen resucitar, en frontispicio similar al de la portada sin su ático; con el mote HAC SOSPITE NVMQVAM/ HOS DERIISSE VIROS, VICTOS/ AVT MORTE FATEBOR; ahora la Fama inmortaliza a todos los biografiados desde Cimabue al propio Vasari.

La obra sigue la estructuración señalada hasta el último volumen que, como integrante de la Terza Parte carece de proemio, pero incluye una breve relación de antigüedades del Pitti y una larguísima referencia de artífices y obras antiguas ${ }^{58}$; siguen las biografías aquí contenidas hasta la de Miguel Ángel, que continúa siendo aún muy importante relativamente y que, de hecho, es la más amplia de las mismas ${ }^{59}$. Y aquí el problema para Vasari, que resolvió muy hábilmente, fue, pienso, "alejar" su propia biografía lo suficiente para que el autoconcluir de facto la obra no evidenciara

58 "Anticaglie che sono nella Sala del Palazzo de Pitti/ Lettera di M. Giovambattista di M. Marcello Adriani a M. Giorgio Vasari/ Artefici antiche in Pittura, in Bronzo, \& in Marmo...".

59 Exactamente la biografía de Miguel Ángel (pp.715-796) cuenta, pues, con ochenta y una páginas, en cambio la del propio Vasari (pp. 980-1010) "sólo" treinta. 


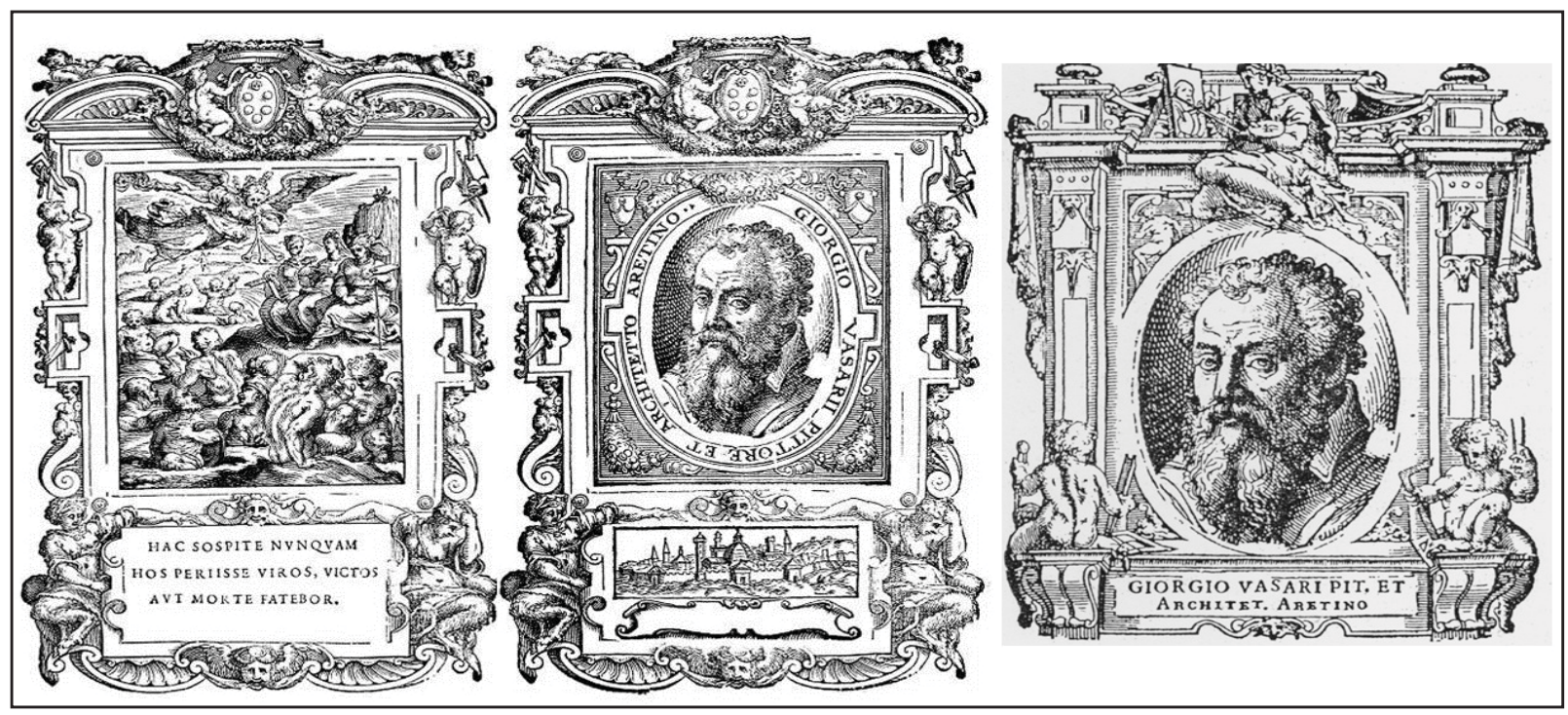

Fig. 12. Vasari, Vite, 1568, xilografías (la Fama inmortaliza a los artistas; Giorgio Vasari como autor y la correspondiente a su autobiografía).

minusvaloración de Buonarroti, habiendo, como se dijo, asentado su posición con el autorretrato del principio. Así varias biografías nuevas ${ }^{60}$ e incorpora una de sus Descrizione, opúsculo ${ }^{61}$ publicado en Florencia, 1565. Tras la cual ya su autobiografía, con un retrato inicial semejante al resto de los incluidos en la obra, con el inocuo epígrafe: Descrizione dell'opera di Giorgio Vasari, Pittore, \& Architetto Aretino.

Respecto a estas Vite, 1568, el referente bibliográfico absoluto sigue siendo la magna edición de Gaetano Milanesi ${ }^{62}$, con sus propios comentarios y notas, en nueve amplios volúmenes; los siete primeros con las Vite vasarianas propiamente dichas, el octavo con los Ragionamenti, no incluidos en la edición giuntiniana ${ }^{63}$ y el noveno con apurados y muy útiles índices, de lo tratado en los volúmenes precedentes ${ }^{64}$.

${ }^{60}$ Biografías de Primaticcio, Tiziano, Iacopo Sansovino, Leone Leoni, Giulio Clovio, "Di diversi artefici italiani", "Di diversi artefici fiamminghi", "Degli Accademici del Disegno", empezando por Bronzino y "Alcuni schiaramenti intorno a Giovanni da Bologna".

${ }^{61}$ Descrizione delle feste per le nozze del principe ereditario Francesco con Giovanna d'Austria; diseños de Vasari, siendo mentor Vincenzio Borghini; estructuras de arte efímero y escenografías de comedias mitológicas con sus "Intermedios", en estos eventos celebrativos encargados oficialmente al aretino.

${ }^{62}$ Casi mítica edición de Sansoni, Florencia, 1878-1881, los ocho primeros volúmenes; el noveno de 1885; reedición, con muevas adiciones del propio Milanesi, Florencia, Sansoni, 1906; sobre esta última, se hizo la edición de Florencia, Sansoni, 1973, 9 vols., con presentación de Paola Barocchi; crítica, que aún se mantiene, a la obra de Milanesi, es no haber incluido los retratos de los biografiados; esto es, las xilografías que el aretino aporta en estas Vite, 1568.

${ }^{63}$ Con algunas cartas del aretino, este volumen octavo de Milanesi, contiene fundamentalmente esta obra póstuma de Vasari, publicada en Florencia, 1588 (Ragionamenti di Giorgio Vasari sopra le invenzioni da lui dipinte in Fiorenza nel Palazzo di LL. altezze Serenissime; vid. CORTI, Laura: Vasari. Catalogo completo dei dipinti. Florencia, Cantini, 1989, pp. 10 y 149; V.V.A.A.: Vasari's Florence. Artist and Literary at the Mediceam Court. Cambridge University Press, 1998 y V.V.A.A.: Vincenzio Borghini. Filologia e invenzione nella Firenze di Cosimo I. Florencia, L. Olschki, 2002)

${ }^{64}$ Es tal la importancia de esta obra de Milanesi que, de algún modo, ha llegado a ser considerada 
Como colofón y conjeturando, quisiera plantear solamente una reflexión para reflexionar, en este caso muy abierta y desde luego nada conclusiva sino como una invitación a pensar seriamente sobre ello.

Deliberadamente se ha eludido en todo el discurso cualquier referencia al Manierismo, porque así con mayúsculas y en el siglo XVI, con unas características y una cronología propias, como se sigue usando -y abusando-, es algo verdaderamente insostenible hoy día; aspectos que han sido aplicados para definirlo, pueden ser válidos previa aclaración de qué, cómo y dónde, y esto resulta más aplicable a las artes figurativas ${ }^{65}$, para la arquitectura -arquitectura construida y no trazas o proyectos en papel- es bastante más ardua la cuestión, entendiendo que es preciso considerar planta, alzado y espacio arquitectónico, no sólo determindas licencias o "desajustes" en alzado respecto a la normatividad clasicista, lo cual no dejarían de ser solecismos de la sintaxis arquitectónica ${ }^{66}$.

Hay que entender que se trata de un arte fuertemente intelectualizado y que apela al intelecto del espectador, tal como, respecto a Vasari, muy a menudo sucede, pero, a renglón seguido, habría que aclarar que esto es lo demandado y que tiene sentido en ámbitos muy elitistas y propio de determinados círculos cortesanos muy refinados y cultos, lo que asimismo es aplicable a buena parte de la producción vasariana.

$\mathrm{Y}$ de inmediato se impone recurrir al contexto, que, casi siempre -por no decir siempre- lo explica y da sentido a todo; se pide y exige al artista obras muy artificiosas, pero que al tiempo ese artificio y el enorme trabajo que ha conllevado no sea notorio. Los términos manieroso, como artificioso y algo positivo, y sprezzatura, como la no evidencia de lo anterior en el resultado final, son los utilizados al respecto e integrantes de ese "arte manierista", en esos "elitistas a ultranza" círculos que lo de-

como la propia fuente; a menudo, el citado volumen octavo es considerado como parte integrante de las Vite, al formar parte de la serie milanesiana; por el contrario, es publicación de su sobrino, con los escritos (Ragionamenti) dello zio, fallecido catorce años antes, y ya dedicada al Gran Duque Ferdinando I de'Medici. Las Descrizioni que Vasari sí incluye en sus Vite, 1568, y Milanesi no, son, en general, "poco visitadas" por los estudiosos del tema; en realidad, fueron varias las Descrizioni, publicadas en Florencia, per i tipi di Giunti, en 1565 y 1568.

${ }^{65}$ Y, desde luego, a las mal llamadas "artes menores"; en el Cinquecento, ante todo la orfebrería que, en modo alguno, puede ser considerada menor. Es más, en el caso concreto de Benvenuto Cellini, el diálogo, la confrontación o mutua "suplantación" entre Escultura monumental y/ u Orfebrería, podría ser considerado como algo muy cercano a un tandem entre artificio y manierismo, desde luego previa aclaración de quiénes eran sus comitentes y la propia intención, poética y técnica apuradísima y exquisita de este artista, como una tensión-oposición muy artificiosa, en algún caso, como la celebérrima Saliera, antes técnica que arte, en palabras de Argan (vid. SUÁREZ QUEVEDO, Diego: "Comentarios y reflexiones sobre los trattati de Benvenuto Cellini. Homenaje en el quinto centenario de su nacimieto", Anales de Historia del Arte, $\mathrm{n}^{\circ} 10$ (2000), pp.71-100 e idem: Arquitectura y ciudad. Memoria e imprenta, op. cit., pp. 59-62 y 108).

${ }^{66}$ Atendiendo de manera simultánea al trinomio planta, alzado y espacio arquitectónico, cabría aludir -y sería, en cualquier caso, un tema abierto y a debate, desde mi punto de vista- a unos pocos ejemplos, bajo la consideración de tensión/-oposición no resuelta: la miguelangelesca Biblioteca Laurenziana de Florencia [Ricetto-Sala de Lectura], c. 1524; palazzo Massimo alle Colonne de Peruzzi en Roma, c. 1534 y a los Uffizi, 1560 y siguientes, de Giorgio Vasari [su patio-calle, puesto en relación con la plaza de la Signoria y su amplio espacio]; en estos casos, tras la reseña de los matices dichos, prudentemente -lo que equivaldría a decir en tanto que- y dado que los criterios de perspectiva, proporción y simetría quedan trastocados, podría acaso plantearse su condición de "manieristas". 


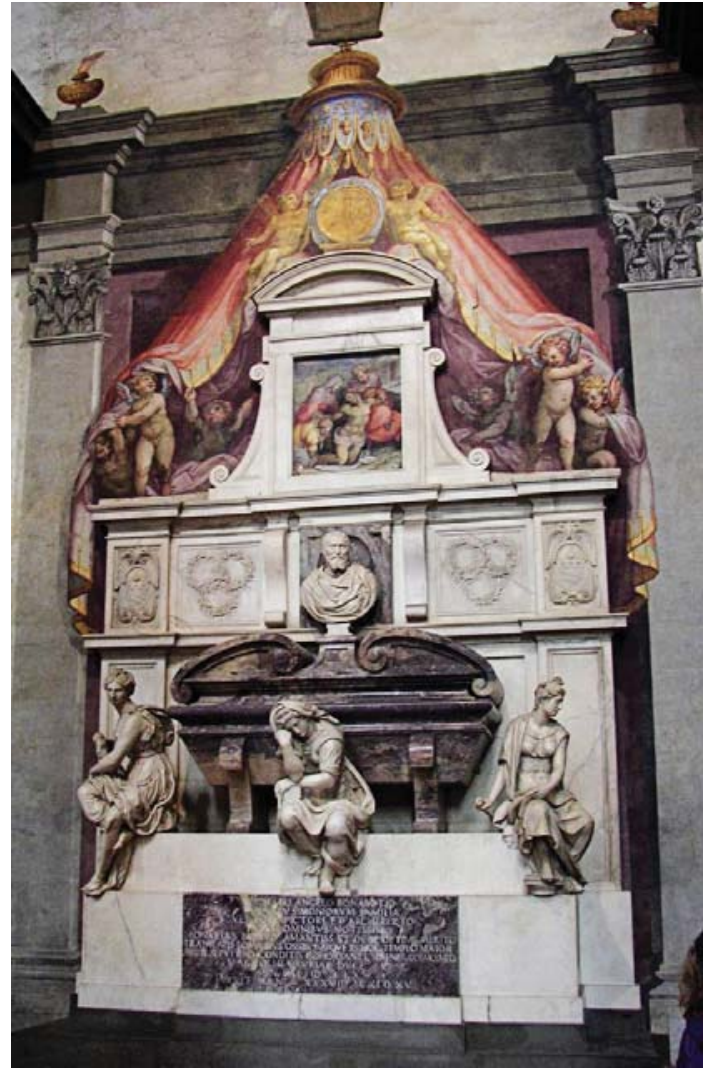

Fig. 13. Vasari, monumento funerario de Miguel Ángel, 1564 y siguientes. Santa Croce de Florencia.

mandan. Tema complejo y espinoso, pero que no se resuelve aplicando el calificativo manierista sin más, y que, esgrimido de este modo, no deja de ser una etiqueta más de las tantas acuñadas por buena parte de la bibliografía del siglo XX, que ha terminado por viciar muchos aspectos del devenir artístico, durante, más o menos, el intervalo 1520 (fallecimiento de Rafael) o 1527( Sacco de Roma) y fines del quinientos ${ }^{67}$.

Por otro lado, suele ser Vasari, con harta frecuencia, el recurrente que sanciona el debate o que lo explica, e incluso hasta se le hace "responsable" del mismo, ante todo en relación con lo que el aretino considera el culmen del arte, lo que él denomina $m a-$ niera verdaderamente moderna, Terza Parte o Terza Età en sus Vite que, no conviene

${ }^{67}$ Deliberadamente fines del quinientos; en el caso de Italia, o sea en el Cinquecento, determinadas tendencias o artistas, ya desde fechas del siglo XVI, formulan propuestas decididamente barrocas, casos de Caravaggio (1571-1610) o los Carracci, tanto en Roma como en Bolonia, ahora centros protagonistas y punteros. Entre otros, son de señalar aquí los datos-hitos siguientes, verdaderamente significativos: Caravaggio en Roma desde 1590, donde, al margen de obras de comitencia privada, con los lienzos de la capilla Contarelli (1599-1600 y 1602; San Luis de los Franceses, Roma), "irrumpe" en un ámbito público. En Bolonia la Accademia degli Incamminati, 1580 y siguientes, tras los ensayos de las del Naturale y dei Desiderosi, con Ludovico, Agostino y Annibale Carracci, este último en Roma desde 1595, donde fallecerá en 1609; Gabriele Paleotti, publica en 1582, y en Bolonia, su decisivo Discorso intorno alle immagini sacre e profane. En cambio en otros centros italianos como en Europa (Francia, Flandes, el Imperio, España), donde el influjo italiano durante el siglo XVI había sido "masivo", se mantienen, prolongan o se repiten hasta bien entrado el seiscientos, soluciones y presupuestos adscribibles más bien a la centuria anterior. El personal naturalismo de Jan Brueghel el Viejo (c. 1525-1569) en el contexto flamenco, sobre todo en obras tardías, apunta hacia modos y poética de un barroco-burgués, muy en sintonía con su contexto. 
olvidarlo, se inicia con la aportación de Leonardo; y lo hace en el correspondiente Proemio tanto en 1550 como en 1568, y en clara y precisa referencia a su héroe, Miguel Ángel ${ }^{68}$. Señala el aretino que, pese a todos los logros conseguidos, para alcanzar la máxima expresión de belleza y una auténtica maniera moderna, faltaba aún al arte -exactamente Mancandoci ancora nella regola- una licenzia (sic), che non essendo di regola, fusse (sic) ordinata nella regola e potesse stare senza fare confusione, o guastare l'ordine ${ }^{69}$; concluyendo tras particularizar todo, que es precisa la referencia al natural, ma artefiziate dal disegno e dal giudizio.

¿Qué concluir o colegir de este reiterativo entrecruce de subjetivismo (licencia que no es de regla) y objetivismo pleno y rotundo (regla y orden)?, con el cuidado, además, de que a ese orden no es lícito producir confusión ni corromperlo y, además, partiendo de la regla. Difícil problemática, casi un dilema, de muy ardua solución, acaso sólo posible a altísimos niveles cualitativos, con un ímprobo trabajo y experimentación, un resultado final de una esmeradísima sprezzatura y para comitencias muy refinadas, exigentes y de altos niveles intelectuales. En mi opinión, si se usa el término "manierista", sin solución de continuidad, se impone casi complementarlo con un "en tanto que", y añadir las razones y/ o argumentos al respecto.

Superados afortunadamente una serie de prejuicios respecto a la producción artística del Cinquecento, como arte decadente, subproducto e incluso como amanerado $^{70}$ o derivaciones secundarias cuando no meras copias sin aliento y colaterales de Rafael o Miguel Ángel ${ }^{71}$, los estudios de Pinelli ${ }^{72}$ y los realizados a propósito

68 Y esto en función, contundentemente, del huomo universalis de Caprese: ... fra i morti e vivi porta la palma e trascende e ricuopre tutti è il divino Michel Agnolo Buonarroti il qual non solo tien il principato di una di queste arti, ma di tutte tre insieme (Proemio a la Terza Parte, Vite, $1550 \mathrm{y}$, también, 1568).

69 Y esto, tanto en las Vite, 1550 como en las Vite, 1568, con texto similar; ese orden que no debe ser corrompido ni objeto de confusón alguna, es el que, il quale, concluye el aretino, aveva di bisogno di una invenzione copiosa di tutte le cose e d'una certa bellezza continuata in ogni minima cosa, che mostrasse tutto quell'ordine con piú (sic) ornamento. Y prolijamente especifica, sin solución de continuidad, lo que esto atañe a las medidas (misure), al diseño (disegno) de las figuras (figure) y sus miembros (un braccio, una gamba, gli occhi), insitiendo en las femmine et i putti y las carnosidades convenientes, y también cómo deben ser las figuras de gli uomini.

70 Manierato, como algo peyorativo, fue esgrimido a menudo desde la crítica seicentesca, es decir, $a$ posteriori; este término, junto a los de manieroso y sprezzatura señalados, fueron estudiados, valorados y resaltados magníficamente a mi entender, pero sin un auténtico ánimo de postergar la etiqueta manierista, por SHEARMAN, John: Manierismo. Madrid, Xarait, 1984 (1 a ed., 1967).

71 Buonarroti que influye y es referente continuo para casi todo, fue realmente un unicum, paradigma y mito de genialidad. Rafael, sinónimo de armonía, belleza y clasicismo, fue un ideal siempre buscado y pocas veces hallado que, de todos modos, no dejó de evolucioinar y experimentar, de tal manera que no es lo mismo el Urbinate de la Signatura, como ha quedado expuesto, que el de La Transfiguración. Y los casos, por sólo aludir a los irrenunciables, de Correggio en Parma; en Venecia Tiziano y Veronés, de un lado, y Tintoretto e incluso El Greco, de otro lado.

72 PINELLI, Antonio: La Bella Maniera. Artisti del Cinquecento tra regola e licenza. Turín, Einaudi, 1993; ambos términos tal como los enunciaba y definía Vasari, son sus pautas. El estudio exhaustivo, atinado y brillante, se ve un tanto ensombrecido desde el momento que la cita y referencia al Proemio a la Terza Età, se hace a patir de Milanesi, esto es sobre las Vite, 1568, como en un segundo momento, cuando el propio Proemio al completo, es exactamente el mismo de la edición torrentiniana de 1550. 
del V centenario del nacimiento en 1494 de Rosso y Pontormo ${ }^{73}$, han contribuido significativamente a obviar la mera calificación estilístico-temporal, adjuntando e imbricando al término maniera rigurosos apoyos y contenciones.

Por otro lado, el devenir complejo y de crisis espirituales y de valores del siglo XVI, fue imponiendo un rechazo de la realidad y el ir obviando el estudio del natural, en pro de alcanzar la artificiosidad demandada, en muchas ocasiones sin un tope o límite, como el disegno e giudizio, recomendado por Vasari, para artefiziare la natura; contención que asimismo quedó cifrada en la maestría y habilidad personales del artista, como fue el caso de Parmigianino, en base a sus innatos sentidos de la elegancia y sofisticación.

\section{Rafael, según las Vite}

La pretensión en este epígrafe es complementar citas, reseñas o datos vertidos respecto a la Signatura y el Urbinate, partiendo de que en este caso las biografías ${ }^{74}$ 1550 y 1568, como quedó indicado, coinciden salvo algún vocablo o matiz, más de redacción que otra cosa. Tanto es así que la descripción del Parnaso efectuada a partir del grabado de Marcantonio Raimondi ${ }^{75}$ y no del fresco de Ralael de 1550 (op. cit. p. 618), sin ninguna corrección por parte del aretino, se repite de nuevo en 1568 (op. cit., p. 71).

Grande por no decir suprema, es la consideración que de Rafael tuvo Vasari; basta aludir y valorar el párrafo siguiente (1550, op. cit., p. 610; 1568, op. cit., pp. 64-65): Di costui fece dono al mondo la natura, quando vinta dall'arte, per mano di Michelagnolo Buonarroti, volle in Raffaello esser vinta dall'arte, è da i costumi insieme.

Nos confirma asimismo Vasari la amistad y relación desde la etapa florentina del Urbinate con Bastiano da Sangallo ${ }^{76}$ : en la ciudad del Arno tuvo domestichezza con giovani pittori, fra i quali furono Ridolfo del Ghirlandaio et Aristotile da San Gallo (1550, op.cit., p. 613; 1568, op. cit., p. 66 [aquí, amicizia en vez de domestichezza]).

73 V.V.A.A.: L'officina della maniera. Varietà e fierezza nell'arte nell'arte fiorentina del Cinquecento fra le due repubbliche, 1494-1530. Venecia, Marsilio, 1996; con el subjetivismo de Rosso y Pontormo, como opción de franca desarmonía, respecto a la pintura de un Andrea del Sarto y su estética.

74 Vite, 1550: "RAFAEL ( $\mathrm{sic}$ ) DA URBINO/ Pittore et Architetto", Volume secondo, pp. 610-641, op. cit. en la edición asimismo citada; Vite, 1568: "Vita di Raffaello da Vrbino Pittore, \& Arch.", op. cit. "Primo Volume della Terza Parte", según ejemplar de la BH, pp. 64-89.

75 Marcantonio Raimondi (c. 1480-c. 1534), importante grabador conocido como Marcantonio Bolognese; en Roma hacia 1510 en el círculo de Rafael; biografía solamente en Vite, 1568, "Primo Volume della Terza Parte/ Vita di Marcantonio Bolognese, e d'altri intagliatori di stampe", pp. 294-312.

76 Bastiano da Sangallo detto Aristotile (1481-1551), arquitecto, escenógrafo y pintor florentino; como diseñador de arquitecturas efímeras consagró su fama participando, 1515, en las estructuras para la Entrada de León X en Florencia, importantísimo evento en relación con los Medici y su "reconciliación y vuelta" florentinas. Biografía sólo en Vite, 1568 ("Secondo, et vltimo Volume della Terza Parte/ Vita di Bastiano detto Aristotile da san Gallo pittore, \& Architetto Fiorentino", op. cit., pp. 536-547) 
De igual modo, precisa el aretino la relación en Florencia con Fra Bartolomeo della Porta ${ }^{77}$, más amplia la reseña en 1550 (op. cit., p. 614), es reducida en 1568 (op. cit., p. 68), pero de igual sentido: Hebbe gl'altri, mentre stette Raffaello in Fiorenza stretta domestichezza con fra Bartolomeo di san Marco, piacendogli molto, \& cercando assai d'imitare il suo colorire: \& all'incontro insegnò a quel buon padre i modi della prospettiua, alla quale non haueua il frate atteso insino a quel tempo.

Interesante a mi juicio resulta el dato contenido en un breve colofón, Conclusione della opera a gli artefici et a'lettori, en las Vite, 1550, justo antes de la citada xilografía de la fama, las tres artes mayores y los artistas muertos, donde el aretino quiere hacer un agradecimiento y un recuerdo a gli scritti da persone degne di fede, insistiendo seguidamente en que mi sono aiutato ancora e non poco de gli scritti di Lorenzo Ghiberti, di Domenico del Ghirlandaio e di Raffaello da Urbino ${ }^{78}$; ¿se trata de la celebérrima Carta a León X de Rafael, redactada seguramente por Castiglione?

De forma más reducida, incluye Vasari ${ }^{79}$ este colofón en sus Vite, 1568 , justo tras su autobiografía, L'autore agl'artefici del disegno, asegurando nuevamente que le han sido di non piccolo aiuto gli scritti di Lorenzo Ghiberti, di Domenico Grillandai (sic) e di Raffaello da Urbino.

\section{Vasari, pintor}

Como pintor y arquitecto se presenta a sí mismo en su autobiografía de las Vite, 1568; en ambos campos artísticos, en efecto, desarrolló una amplia labor profesional, con obras de un refinado y muy cuidado diseño ${ }^{80}$, y para comitentes altamente exigentes.

Desplegó su importante actividad pictórica sobre todo en Bolonia, Venecia, Nápoles y en su Arezzo natal, pero lo más significativo de su producción se centró en Roma y Florencia ${ }^{81}$; pintura, en general, fuertemente intelectualiza que deno-

${ }^{77}$ Fra Bartolomeo, Baccio della Porta (1472-1517); en Vite, 1550: "Fra'Bartolomeo di San Marco. Pittor (sic) Fiorentino", op. cit. Volume secondo, pp. 579-586 y Vite, 1568, op. cit. "Primo Volume della Terza Parte/ Vita de fra Bartolomeo di s. Marco pittor (sic) fiore.", pp. 34-41.

${ }_{78}$ Parece claro que alude a los Comentarios de Ghiberti; respecto a Ghirlandaio, nada sabría decir. En relación con el Urbinate, vid. Raffaello. Gli scritti. Lettere, firma, sonetti, saggi tecnici e teorici, a cura di Ettore Camesasca con la colaborazione di Giovanna M. Piazza. Milán, Biblioteca Universale Rizzoli, 1994.

${ }^{79}$ En estas Vite, 1568, tras las dedicatorias -ahora son dos- al duque Cosme I de'Medici y previamente al proemio general de la obra, añade un apartado que, de modo muy significativo en relación a su condición de autor, como ya quedó reseñado, titula Agli artefici del disegno/ Giorgio Vasari”, donde, plenamente satisfecho de su obra, da constancia de haber concluido con la aggiunta prometida dieciocho años antes.

${ }^{80}$ Il primato del disegno, en la produción y cultura artísticas del Cinquecento, alcanzó seguramente su ápice, confirmación y constatación en el conjunto de la obra del aretino (vid. RAGGHIANTI COLLOBI, Licia: Il Libro de'disegni del Vasari. Florencia, Vallecchi, 1974, 2 vols.).

81 Vid. CORTI, Laura, op. cit. y Les peintres toscans/Vasari; textes réunis et présentés par André 


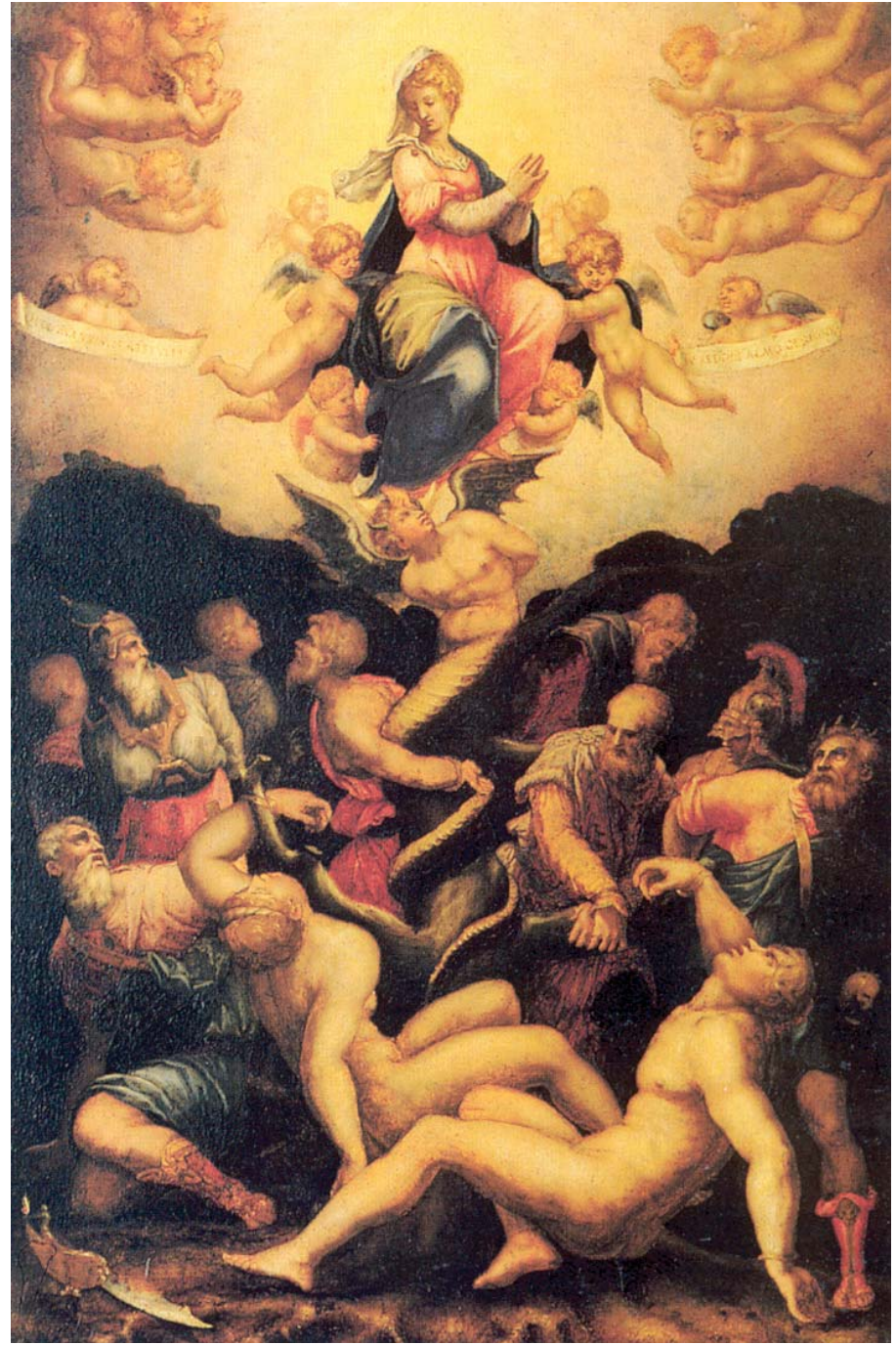

Fig. 14. Vasari, Alegoría de Concepción, c. 1541. Uffizi, Florencia.

ta, como él mismo reseña, su continuado contacto y asesoramiento con consumados humanistas y literatos tales como Paolo Giovio, Benedetto Varchi o Vincenzio Borghini, pero atendiendo a otros horizontes según la naturaleza del encargo y el locus de colocación y exposición de la obra; una mínima semblanza al respecto, pero aún así significativa, será lo aquí apuntado ${ }^{82}$.

Interesantísima es la Alegoría de la Concepción, obra encargada por Bindo Altoviti, cónsul florentino en Roma, para la capilla familiar de esta advocación en la iglesia de SS. Apostoli de Florencia; el propio Vasari en su autobiografía ${ }^{83}$ describe minuciosamente la complejidad de la composición, al tiempo que reseña, según carta dirigida al comitente, el haber atendido il parere di molti comuni amici, uomini letterati, ante todo, Giovanni Lappoli ${ }^{84}$ detto il Pollastra. Además de varias copias,

Chastel. París, Hermann, 1966.

${ }^{82}$ Un más amplio panorama en SUÁREZ QUEVEDO, Diego: "Giorgio Vasari pittore aretino", en “Apuntes de Arte y Sociedad", no 3 (junio, 2011), pp. II-VII, op. cit., pp. 14-19.

83 Vite, 1568, pp. 989-990.

84 Aretino como Vasari, era asimismo conocido como il Pollastrino (1465-1540), vid. Julian KLIEMANN: "Vasari, Pollastra e l'alegoria della Concezione", en Giorgio Vasari. Principi, letterati e 


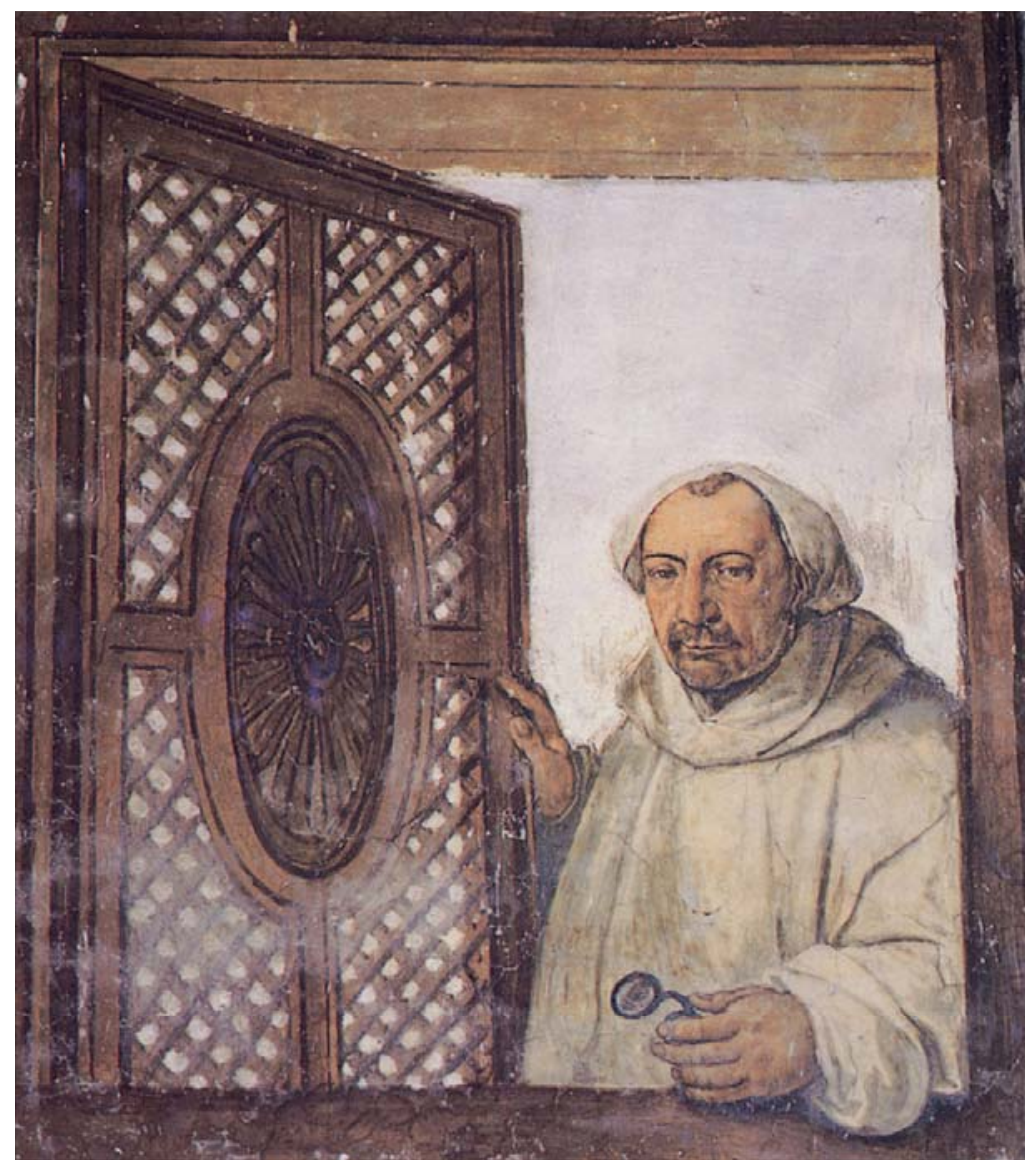

Fig. 15. Vasari, Retrato de monje olivetano, 1544-1545; fresco en el corredor de la sacristía, monasterio de los olivetanos de Nápoles.

han llegado hasta nosotros, con pequeñas variantes y de diversos tamaños, al menos cinco réplicas que realizara el aretino, las más tardías en 1541 y 1543; además de la primigenia en la señalada iglesia florentina, están hoy en S. Salvatore de Fucecchio, en el Ashmoleam Museum de Oxford, en la Pinacoteca de Villa Guinigi de Lucca, en el Nuseo Stadale di Arte Medievale e Moderna de Arezzo y en los Uffizi de Florencia.

Según nos testimonia el propio Vasari adquirió una casa en Arezzo (contrato estipulado el 7 de septiembre de 1541) en el borgo de San Vito, nella miglior aria di quella città. De vuelta de Venecia y durante su estancia aquí, inició la decoración al fresco en la denominada Sala de la Fama y de las Artes, representando tutte l'Arti che sono sotto il disegno, o che da lui dependeno, evidente manfiesto del pensamiento del artista. En torno a la Fama dispone la Poesía como idea e ideal de belleza, la Pintura, la Escultura y la Arquitectura. Los óvalos con retratos del natural de los que considera primeros delle nostre arti, fueron seguramente completados después de 1568, dada su evidente derivación de las xilografías de las Vite publicadas en Florencia ese año; representan a Miguel Ángel, Andrea del Sarto, Luca Signorelli, Spinello Aretino, Bartolemeo della Gatta, Lazzaro Vasari y el propio Giorgio Vasari. En los años 1548 y 1553-1554, completó la decoración de su casa de Arezzo en varias estancias:

artisti nelle carte di Giorgio Vasari. Pittura vasariana dal 1532 al 1554 (catálogo de la exposición de igual título en Arezzo). Florencia, Edam, 1981, pp. 103 y ss. 


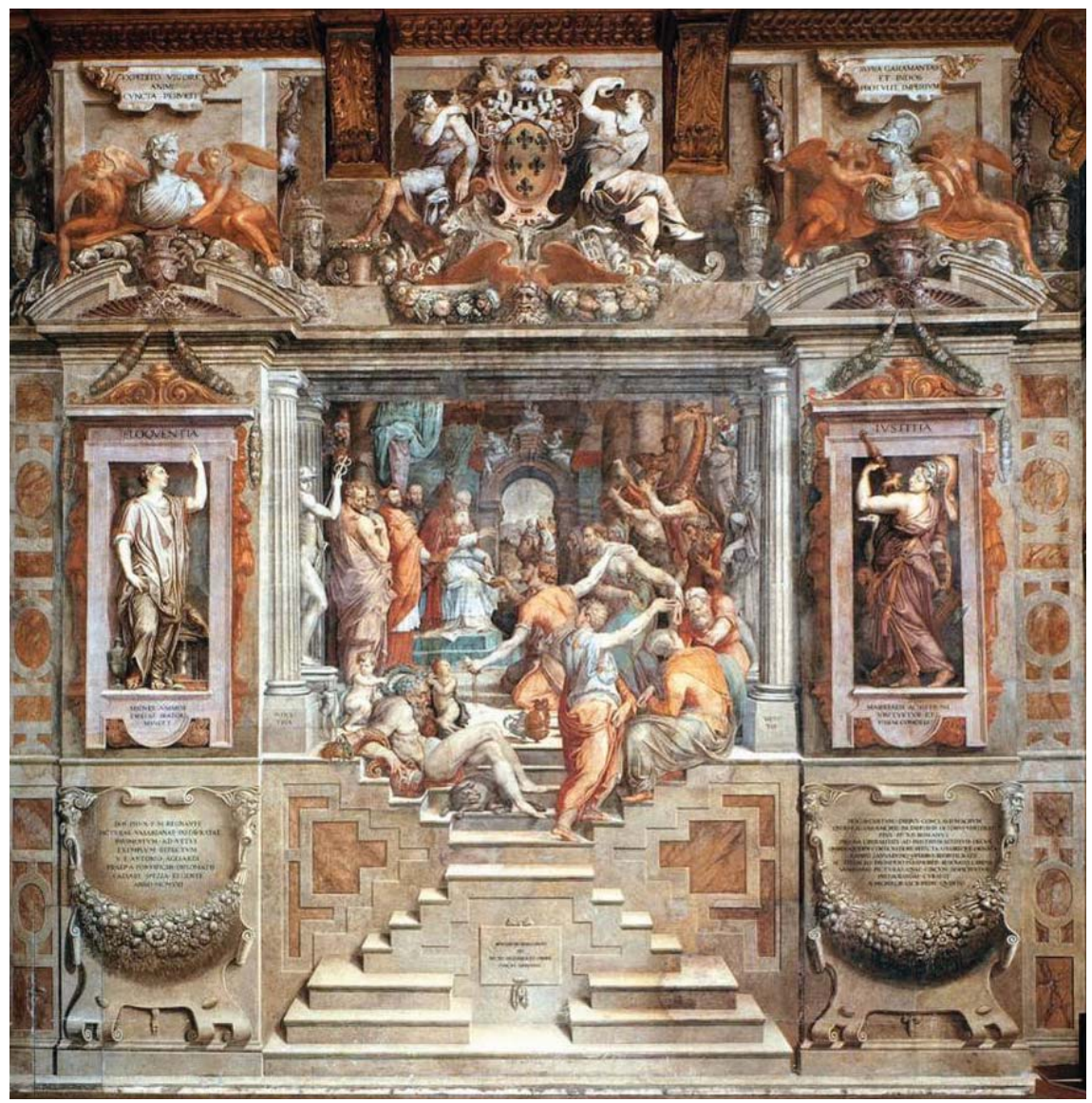

Fig. 15. Vasari, Paulo III recibe el homenaje de las naciones, 1546, fresco de la Sala dei Cento Giorni, Cancillería Apostólica, Roma.

Cámara de Abraham; Corredor de Ceres; Sala del Triunfo de la Virtud y Cámara de Apolo y las Musas, precisándonos que haciendo memoria de las obras de los antiguos, la feci tutta a tempera. En sede de una importante institución museístico-cultural, ha devenido en ser este inmueble, de actualidad recientemente, ya que al impedir el gobierno italiano la salida del país de un importante contingente archivístico vasariano (embargo impuesto en marzo de 2009 y levantado en diciembre de 2010), ha quedado éste depositado en esta Casa Vasari de Arezzo.

Ejecutó una serie de tablas y frescos para el monasterio de los Olivetanos de Nápoles, por encargo de su General Giammatteo D'Anversa, en 1544-1545 y siguientes; por su verismo y planteamiento quasi ilusionista, es destacable el fresco, aún in situ en el corredor de la sacristía, con el Retrato de monje olivetano.

Habría que referenciar aquí la Sala dei Cento Giorni, encargo farnesiano muy prestigioso según un amplio programa elaborado por Paolo Giovio en la Cancillería Apostólica de Roma.

La tela de los Pescatori, de la Walpole Gallery de Londres, de sabor costumbrista y decorativo, pareja de los Uccellatori, en colección privada de Gran Bretaña, y ambos fechables c. 1565 , son obras de Vasari que deben ser relacionadas, al menos en cuanto a la fase de ideación, con la serie de tapices, bajo diseños de Stradano, para la villa medicea de Poggio a Caiano. 


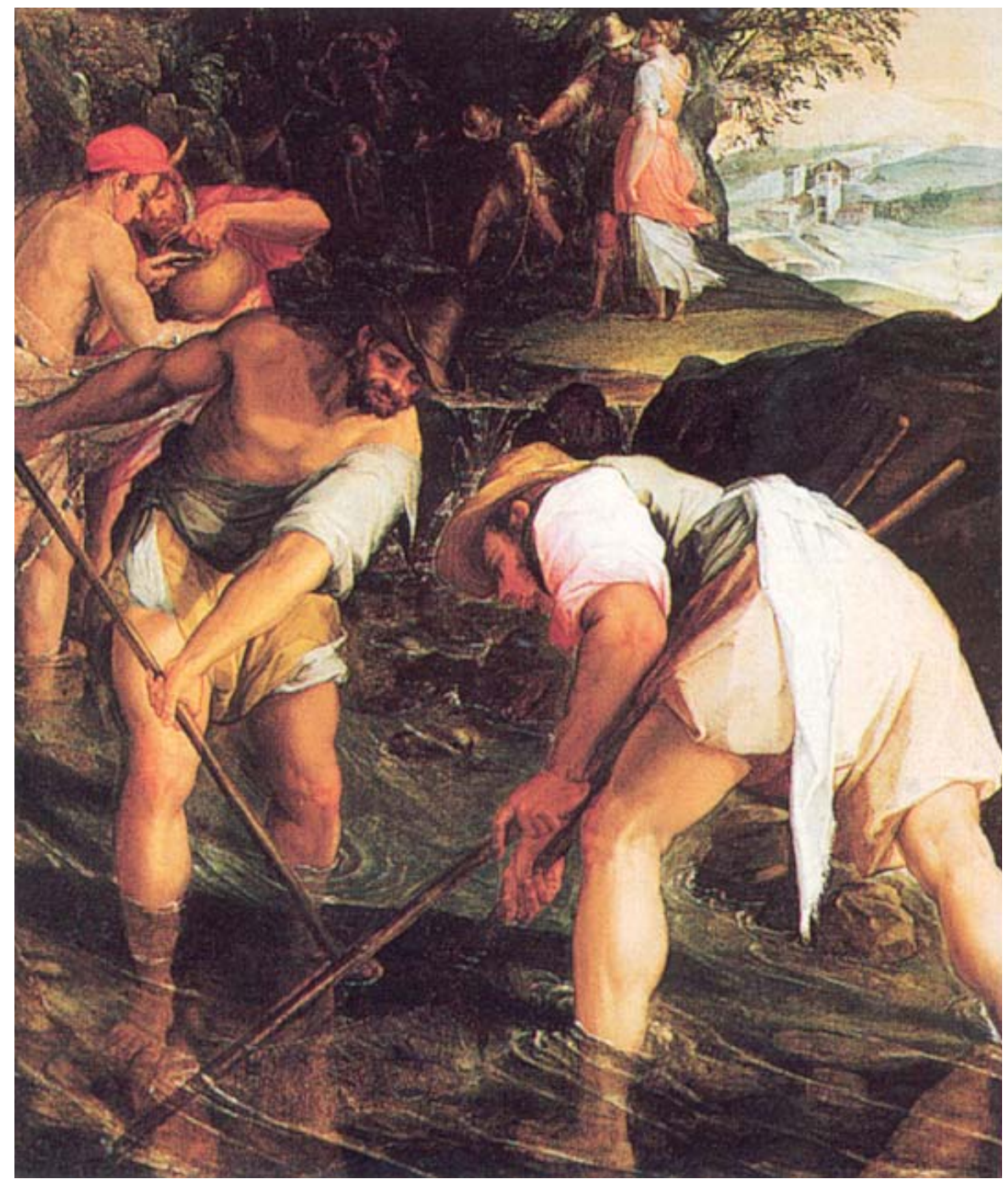

Fig. 17. Vasari, Pescadores, c. 1565. Walpole Gallery, Londres.

Vasari, desde 1555 hasta su muerte fue, en la corte medicea de Cosme I, el artista oficial, lo cual significaba entonces ser quasi un funcionario, "obligado" a dar respuestas plurales a todas las demandas de este exigentísimo ámbito; con todo un equipo de maestros y oficiales bajo sus dictámenes, estuvo a la altura de las circunstancias y demostró una capacidad de organización en una actividad, de prácticamente veinte años, verdaderamente frenética. Ante todo en la conformación del palazzo Vecchio como sede y núcleo oficiales de la corte ducal, adaptando y redecorando los diversos ámbitos públicos y privados. Crucial era la empresa del Salone dei Cinquecento donde, al margen de la calidad intrínseca de las obras, queda fehacientemente plasmada la idea del duque Cosme I como un nuevo Augusto, su principado una nueva Edad de Oro para Florencia y la superioridad del Ducado sobre la República; significaba la culminación de la sagaz maniobra del duque asentándose en el umbilicus del palacio de la Signoria, sede-recuerdo de las libertades y prerrogativas republicanas que, de este modo, quedaban subsumidas y anuladas. 


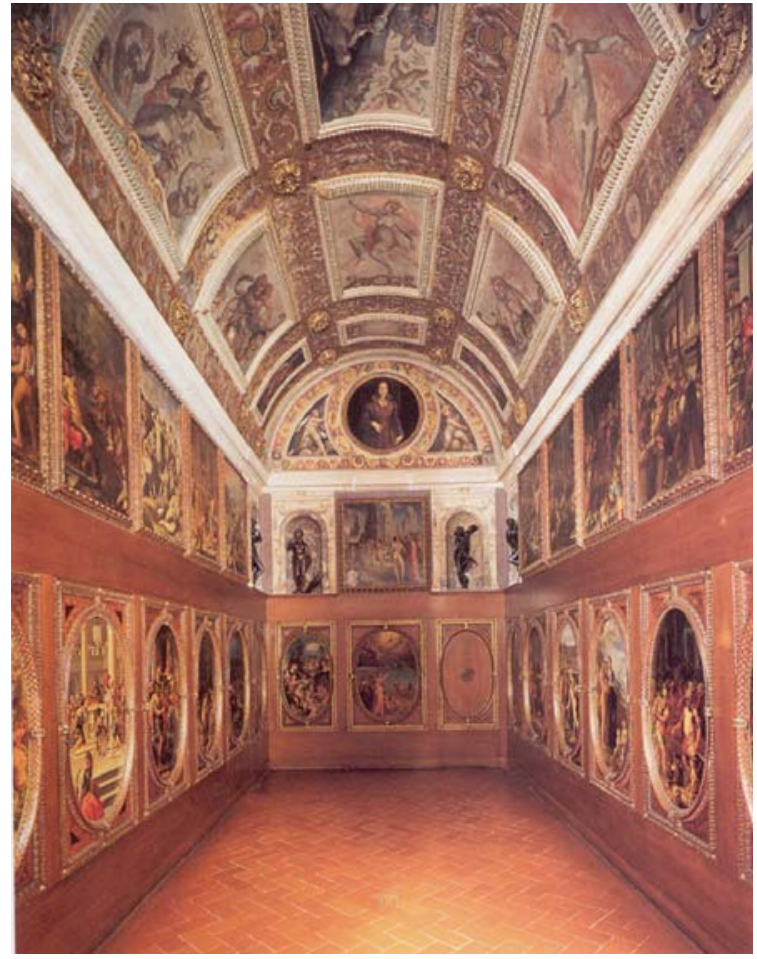

Fig. 18. Stanzino del príncipe Francisco de’Medici, 1570-1572. Palazzo Vecchio, Florencia.

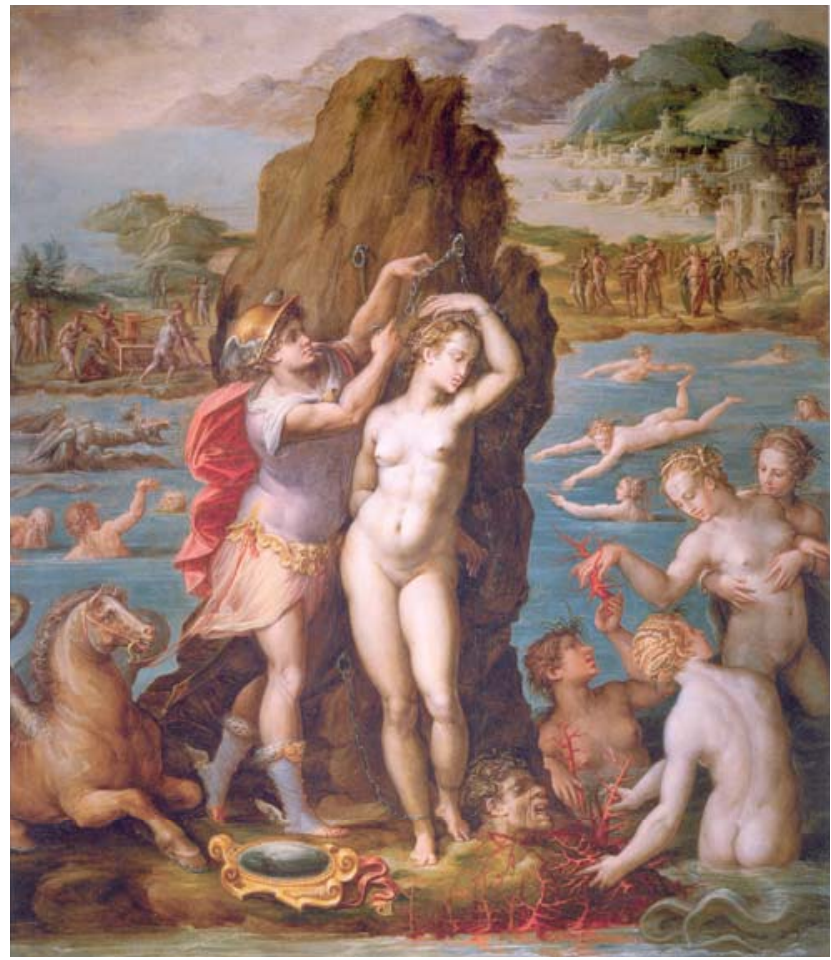

Fig. 19. Vasari, Perseo libera a Andrómeda, 1572, en el Stanzino.

El comunmente denominado Studiolo de Francesco I de'Medici, en el palazzo Vecchio y hoy comunicado con el Salone dei Cinquecento, lo es impropiamente; en realidad era conocido como Stanzino al que gustaba retirarse al príncipe heredero, a un mismo tiempo laboratorio de sus intereses científicos y mágico-alquímicos y auténtica Cámara de Maravillas donde quedaban expuestos en armarios tras los paneles de madera de las paredes, que podían abrirse, los objetos raros y preciosos que atesoraba. Fue confeccionado durante el intervalo 1570-1572 bajo dirección y supervisión de Vasari, con Borghini como mentor, a modo de interconexión entre figuración y colección de piezas de arte y de maravilla, según un sistema de "arte de la memoria" cercano a ideas de Giulio Camillo Delminio y su Teatro della Memoria. La bóveda de la pequeña estancia sin una sola ventana fue decorada al fresco, en tanto que pequeños cuadros fueron dispuestos sobre los citados paneles lígneos, con temas ad hoc.

Desmantelado en 1590, fue recompuesto en 1919 acopiando los cuadros dispersos, dos de los cuales no han sido hallados, acaso porque nunca llegaron a realizarse. Vasari quiso contribuir personalmente a este precioso ámbito con un quadretto [óleo sobre pizarra; 117 x $100 \mathrm{~cm}$.] de amplio y profundo fondo con el tema de Perseo que libera a Andrómeda; en primer plano, y en sintonía con el locus e intereses del príncipe Francesco, aparece la cabeza de Medusa de la cual parten hilos de sangre que, al caer al mar, van conformando corales.

La última gran obra de Vasari en el campo pictórico, que a su muerte en 1574 no estaba concluida, fue el diseño de los frescos a realizar en el interior de la cúpula de Santa Maria del Fiore de Florencia. Comisionada al aretino en 1571 por el ya Gran 


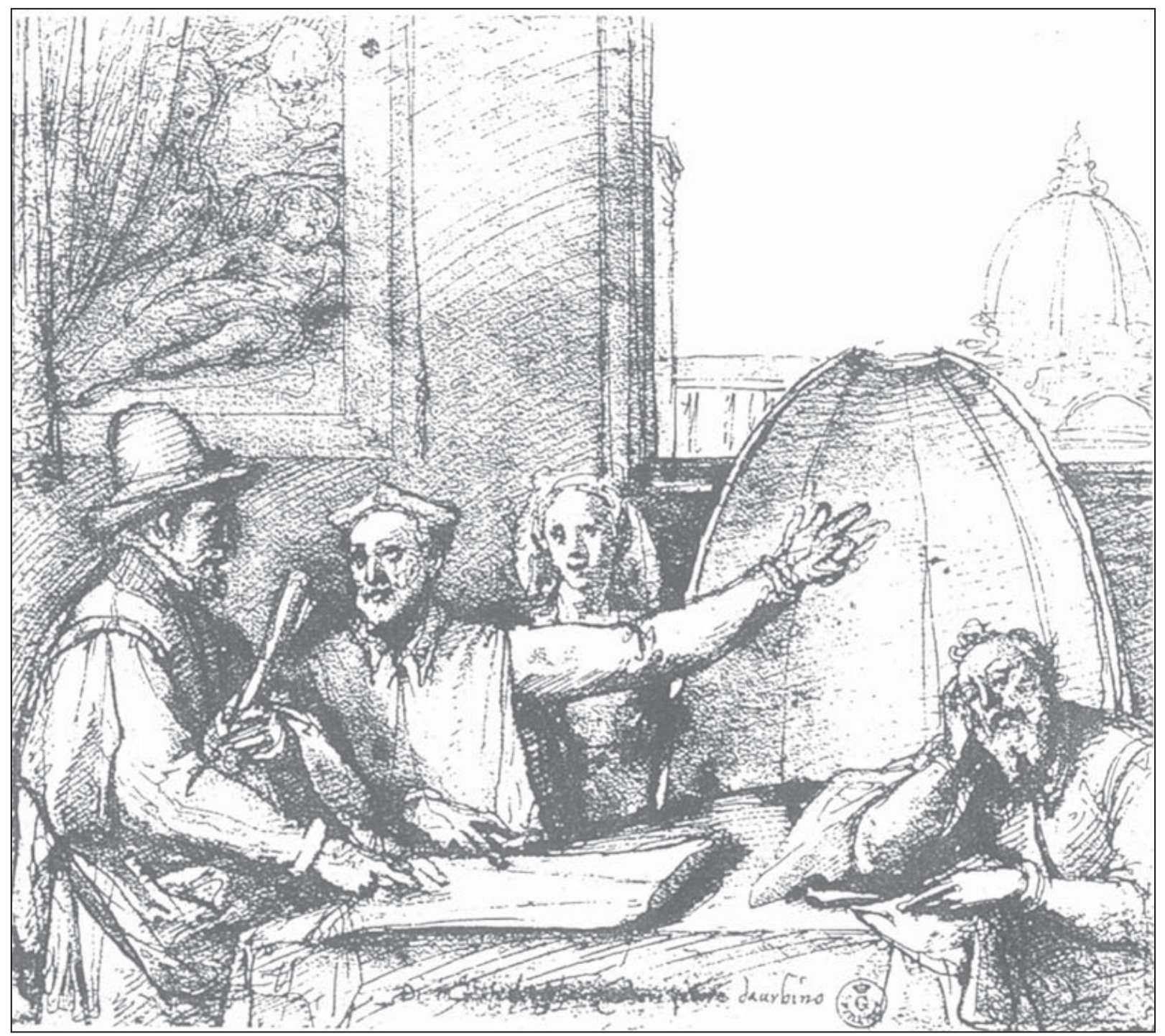

Fig. 20. Zuccari discute con Borghini sobre los frescos de la catedral de Florencia, con Vasari adormilado y en presencia de Cosina. [Uffizi, GDSU 11043 F].

duque -desde 1569- Cosme I, se iniciaron los trabajos en 1572; no obstante, consta el empeño conjunto de Vasari y Borghini desde unos cuatro años antes, en adecuar a los ocho amplios paños brunelleschianos, las partes del inmenso Juicio Universal ideado por el primero con asesotamiento del segundo, y la consiguiente preparación de los cartones; finalmente fue Federico Zuccari el encargado de rematar la obra tras la desaparición del aretino. Varios dibujos parciales de esta obra se conservan en el Louvre; por otro lado, resulta elocuente per se el dibujo ${ }^{85}$ en que Zuccari discute con Borghini sobre los frescos de la catedral de Florencia, con Vasari adormilado y en presencia de Cosina.

${ }^{85}$ Uffizi (GDSU 11043 F); Cosina es diminutivo de Nicolosa de'Bacci, esposa de Giorgio Vasari, que gustaba de llamarla así. 


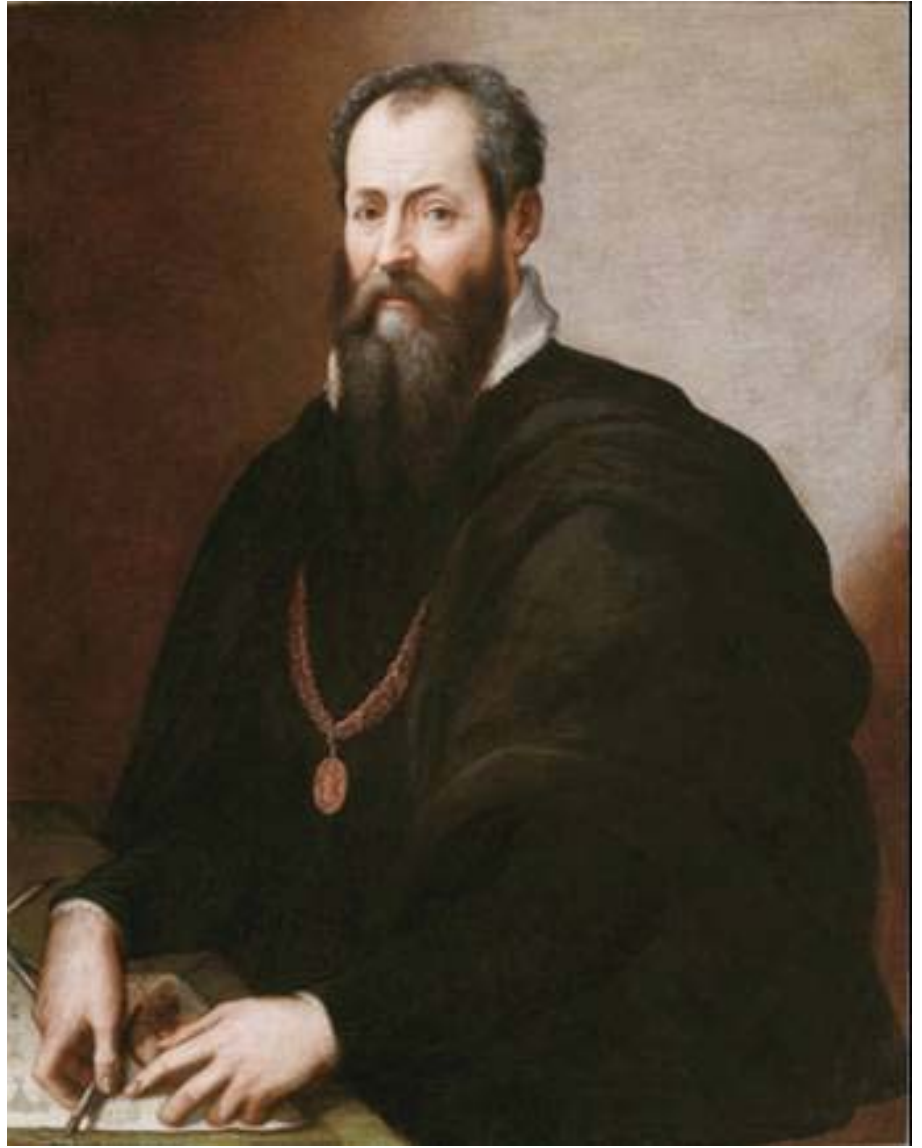

Fig. 21. Retrato (posterior a 1571) de Vasari del círculo del aretino.

\section{Vasari, arquitecto}

La gran empresa arquitectónica vasariana fue, sin duda alguna, la planificación y construcción de los Uffizi, 1560 y siguientes, como sede de los diferentes entes públicos que, diseminados por toda la ciudad mantenían su conformación jurídica tradicional y una relativa parcela de poder más nominal que efectivo; ahora, en torno al palazzo Vecchio y plaza de la Signoria, no sólo gravitaban en torno al nuevo centro primigenio oficial, sino que su control era efectivo y total. Se trata de dos unidades arquitectónicas dispuestas a ambos lados de una calle-patio, con sus soportales, hasta el Arno ${ }^{86}$; obra que fue exaltada y presentada como de PVBLICAE COMMODITATI, según reza el reverso de la medalla fundacional correspondiente ${ }^{87}$.

El complemento de esta obra fue el pasadizo sobre la ciudad y sobre el Arno ${ }^{88}$, Corridoio Vasariano, que enlazaba el palazzo Vecchio -Regal Palazzo, en denomi-

86 Más exactamente hasta el Lungarno, con un previo y efectivo elemento en serliana; vid. LOPEZOSA APARICIO, Concepción: "Vasari arquitecto", "Apuntes de Arte y Sociedad", no 3 (junio 2001), pp. XIII-XVI, en CDL, junio de 2011, op. cit., pp. 25-28.

87 Domenico Poggini, 1561; anverso Cosme I como duque de Florencia y Siena; reverso: Uffizi. Museo Nazionale del Bargello, Florencia.

88 Vid. CANEVA, Caterina-MOTTURA, Paolo-BERTELLI, Sergio-MOROLLI, GabrieleMOROMCIU, Marcella-MELONI TRKUIJA, Silvia-ROMUALDI, Antonella: Il Corridoio vasariano agli Uffizi. Milán, Silvana, 2008. 


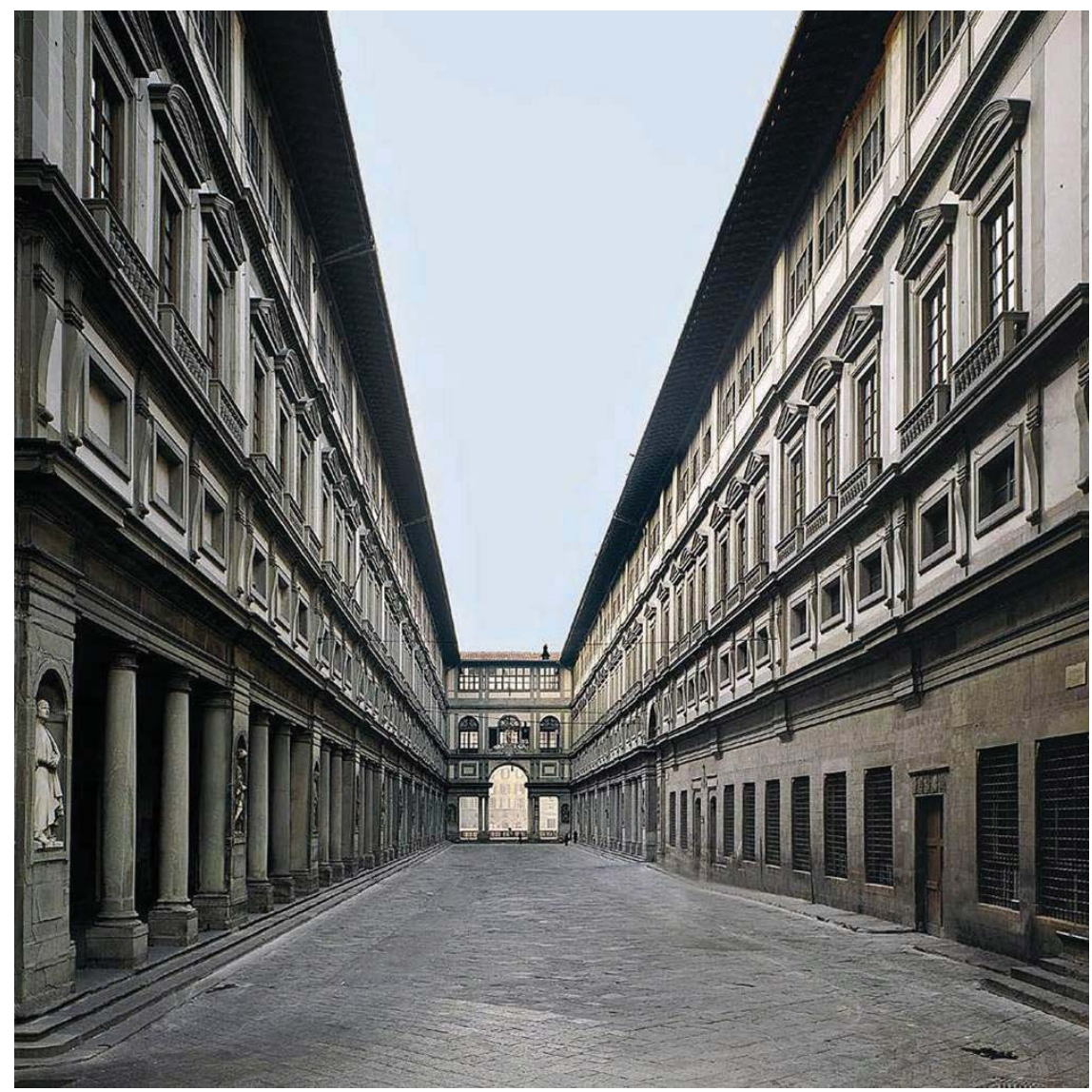

Fig. 22. Vasari, Uffizi, 1560 y siguientes.

nación de la época- centro neurálgico oficial, con el palazzo Pitti, en Oltrarno, ahora Reggia privata.

Las denominadas Logge vasariane que, para su ciudad natal proyectó en 1572, con toda su signicación y operatividad cívicas, constituyen una importante adaptación, como idea arquitectónica, a la escala y necesidades de Arezzo, a partir de la citada obra florentina

A nivel de proyecto ${ }^{89}$, antes de su asentamiento en Florencia, cabe aludir a los diseños, c. 1550, para la Villa Giulia -en su momento Vigna di papa Giulio- extramuros de Roma en via Flaminia, así como, a la continuación de las obras de rehabilitación de la villa medicea de Castello, de las cuales se hizo cargo el aretino a la muerte, 1550, de Niccolò di Raffaello Pericoli detto il Tribolo, que más tarde asumió Bernardo Buontalenti y nunca completadas según el ambicioso programa y envergadura del proyecto, que mediante jardines, acequias y alguna fuente, conectaba la citada villa con la ciudad de Florencia; proyecto que conocemos precisamente por la minuciosa descripción vasariana, incluida en la biografía de Il Tribolo de las Vite, 1568.

Construcción muy interesante, a mi juicio, es la del Palazzo della Carovana o dei Cavalieri di Santo Stefano, 1562-1567, en Pisa (Piazza dei Cavalieri), como sede y referente de la recién creada Orden de Caballería de San Esteban, por el duque 1993.

89 Respecto a la arquitectura del aretino, vid. CONFORTI, Claudia: Vasari architetto. Milán, Electa, 


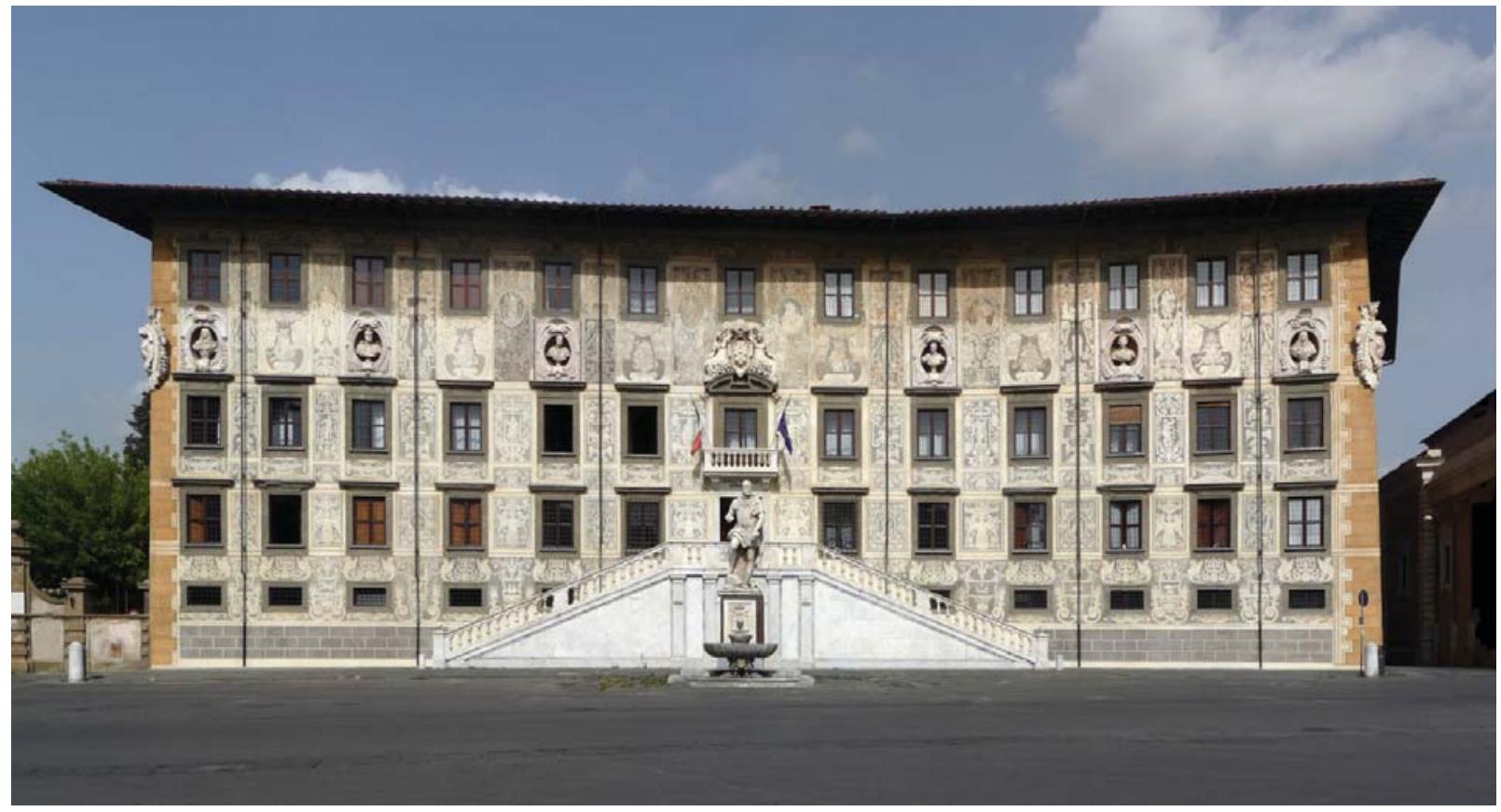

Fig. 23. Vasari, Palazzo della Carovana o dei Cavalieri di Santo Stefano, 1562-1567, Pisa.

Cosme I; verdaderamente fue la reestructuración y rehabilitación de dependencias y estructuras arquitectónicas preexistentes, que quedaron tras una amplia fachada dominada y definida, en toda su superficie con sencillos vanos rectangulares, mediante un despliegue de refinados esgrafiados y unos bustos en sus correspondientes nichos. En su centro y como acceso, una doble escalinata, de raigambre miguelangelesca, a base de tramos laterales. 